\title{
2009/34
}

Winners and losers among a refugee-hosting population

Jean-François Maystadt and Philip Verwimp 
CORE

Voie du Roman Pays 34

B-1348 Louvain-la-Neuve, Belgium.

Tel (32 10) 474304

Fax (32 10) 474301

E-mail: corestat-library@uclouvain.be http://www.uclouvain.be/en-44508.html 


\title{
CORE DISCUSSION PAPER
}

$2009 / 34$

\section{Winners and losers among a refugee-hosting population}

Jean-François MAYSTADT ${ }^{1}$ and Philip VERWIMP2

May 2009

\begin{abstract}
Every year, thousands of refugees are forced to leave their countries of origin and are hosted by their neighboring countries. However, very little is known about the impact of these refugees on the local economy and its inhabitants. Based on hypothesis formulated during a two-month iterative field research, a theoretical framework is used to understand how the refugee inflow would affect the good and labour markets of the local economy. We then test the theoretical predictions regarding the potential winners and losers among the refugee-hosting population, using household panel data collected in the region of Kagera in Tanzania. Our identification strategy exploits both time and spatial variations in the way households traced between 1991 and 2004 have been affected by the refugee inflows originating from Burundi (1993) and Rwanda (1994). Our results show that local hosts do not necessarily suffer from the refugee presence. Net economic benefits could even emerge provided a sufficient mass of refugees is gathered. Furthermore, the economic benefits appear to be unevenly distributed among the refugee-hosting population. Agricultural workers are likely to suffer the most from an increase in competition on the labor markets and the surging prices of several goods. On the contrary, non-agricultural workers and self-employed farmers are in a better position to benefit from such a refugee inflow. We also conjecture that the welfare deterioration experienced by those involved into business could be explained a selection effect resulting from the reported entry of larger-scale entrepreneurs from other regions.
\end{abstract}

Keywords: refugees, Tanzania migration.

JEL Classification: O12, O18, R12, R23

${ }^{1}$ Université catholique de Louvain, CORE, B-1348 Louvain-la-Neuve, Belgium.

E-mail: jean-francois.maystadt@uclouvain.be

${ }^{2}$ Fund for Scientific Research (FWO) and University of Antwerp

This paper presents research results of the Belgian Program on Interuniversity Poles of Attraction initiated by the Belgian State, Prime Minister's Office, Science Policy Programming. The scientific responsibility is assumed by the authors. 



\section{Introduction}

Every year, thousands of people are forced to leave their countries in a desperate attempt to find a safe heaven, their life being threatened by civil conflicts. End of 2007, UNHCR (2007) reported 11.4 million refugees in the world, whose 2.2 million originated from Sub-Saharan Africa. Contrary to some popular ideas, these refugees do not invade the industrialized world but are in widespread majority, hosted by their neighboring countries. Media and host governments have often pressured the international community to help them in supporting the burden induced by this massive inflow of refugees. However, very little is known about the exact nature of the impact of the refugees on the local hosts. From a policy point of view, the United Nations High Commission for Refugees (UNHCR) seems increasingly aware that the issue of the impact of the refugees on their local hosts has been overlooked for too long. For example, in Tanzania, the UN agency for refugees is implementing a new program easing the transition phase following the closure of all camps in the region of Kagera. ${ }^{1}$ A better understanding of the main channels through which the local population is affected by massive refugee inflows would help in improving the efficiency of such programs.

Our collective memory tends to perceive refugee camps as an unorganized mass of temporary tents and occupied by passive refugees under assistance. Nevertheless, this common view is far from many experiences. First, some temporary situations can end up by lasting sometimes very long. This has resulted in what UNHCR has called the problem of protracted refugee situations (Crisp, 2003; Slaughter and Crisp, 2009). City-sized refugee camps have mushroomed in often very poor areas, where inhabitants themselves struggle to make a living. Despite their traumatic experiences and their poor health conditions when they arrived, still these refugees came in with productive capacities, even with some assets (human capital, livestock, etc) or at least, keep networks to get access to these assets (de Montclos and Kagwanja, 2000; Werker, 2007). Therefore, refugees are likely to endorse some important economic functions and have significant impacts on their hosts' livelihoods. The purpose of this paper is to contribute to a better understanding of the longterm impact of refugees on the local communities. We combine fieldwork collected information and the very comprehensive Kagera and Health Development Survey to identify how the local population has been affected by the refugee inflows originating from Burundi (1993) and Rwanda (1994) in the region of Kagera (North-Western Tanzania).

The issue of the impact of a refugee settlement on local economies does not seem

\footnotetext{
${ }^{1}$ In June 2008, the Lukole camp (Ngara district) was the last camp of the region of Kagera to be closed making the Kagera region free of refugees for the first time since about 15 years.
} 
to have attracted very much research interest. As far as we know, Chambers (1986) in an article entitled "Hidden Losers? The impact of rural refugees and refugee programs on poorer hosts" is the first to have paid attention to this issue. Based on scattered evidence and rural experiences, this author argues that the presence of a refugee camp has mixed consequences for the host population through an increase in price, wage competition and competition for natural resources. The better-off and more visible hosts would be more likely to gain from the presence of refugees and refugee programs while by contrast, poorest hosts could loose from competition for food, work, wages, services and common property resources. He points to these vulnerable hosts as the hidden losers. Since then, authors such as Kuhlman (2002), Whitaker (1999), Landau (2004) and several papers from the UNHCR' s Evaluation and Policy Analysis Unit have provided field-work support of this contrasted impact. Unfortunately, the state of knowledge is not much more advanced than the "scattered evidence" on which Chambers (1986) bases his analysis. As summarized by Whitaker (1999, 2), "refugees are assumed to have a different impact on diverses classes, genders, sectors and regions within the host country, but little empirical evidence has been done on this issue."

Few economists seem to have paid attention to this subject or at least, related ones. Some authors such as Hatton and Williamson (2004) focus on the causes that lead refugees to seek asylum in developed countries and in particular, in the European Union. They also study its impact on native-born workers. In a crosscountry setting, Azam and Hoeffler (2002) also test empirically the factors explaining the number of refugees per country of origin. Stark (2004) formalises the dynamic process that distinguishes a refugee flow from an immigration move while Bubb et al. (2007) theoretically study the system of refugee protection based on the 1951 Convention Relating to the Status of Refugees as a Pareto-improving contract that bound states to provide a more efficient level of the global good of protection. The issue of efficiency of food aid which is also related to the subject has also been much studied. Its impact on prices and trade have been explored by notably Barret (2002), Dercon and Krishnan (2004), and Donovan et al. (2006). ${ }^{2}$ Nevertheless, those subjects are much more general than the presence of refugees, per se.

As far as we know, two papers are much closer to ours, at least in studying

\footnotetext{
${ }^{2}$ Our paper is also related to studies assessing the impact of migrants on local labour markets (Card, 1990; Hunt, 1992; Ottaviano and Peri, 2006; Borjas, 1999, for a review). However, our approach differs from these wage-type equation analysis in the sense that we seek to undertake a broader assessment of the impact of refugee inflows on the welfare of the local population, not restricted to labour employment. It indeed appears from observations made on the field that refugees along with the aid provided by the international community have had very wide impacts on the economic structures of the region of Kagera.
} 
related issues in the Tanzanian context. Based on two different sets of data, AlixGarcia and Saah (2008) assess the impact of the proximity to a refugee camp through changes in agricultural prices between 1995 and 1998. They also test the impact of massive refugee inflows on the holding of assets. Two important results might be emphasised. On the one hand, they found a significant increase in the prices of some agricultural goods (bananas, beans and milk) and a decrease in the price of the aid-delivered good (maize). On the other hand, they found a positive impact on the acquisition of more valuable assets. Based on a richer dataset encompassing information on consumption, income and other household characteristics, our paper provides a complementary - general equilibrium inspired - piece of evidence. While our paper focuses on the differentiated impact on the welfare of the local population via their occupations, our identification also differs in the scale of the phenomenon. AlixGarcia and Saah (2008) use a nation-wide survey, where proximity to the refugee camps has a different meaning than ours. While about $13 \%$ and $6 \%$ of their households are located in wards within respectively 200 and 100 kilometers of the closest refugee camps, all and $96 \%$ of our sample are located within the same radius. To achieve similar percentages, our households need to be located between 10 and 30 kilometers. ${ }^{3}$ Given the reported effects (see section 2.2) and the high transport costs in the region, we have some good reasons to believe that the impacts of the refugee camps are highly localized. We are also concerned that an excessively large scale of analysis will capture unobserved and time-variant regional effects. Another related paper is the one by Baez (2007) who assesses the short and long run effects of hosting refugees on health conditions of children. The author offers evidence of adverse impacts, almost 1.5 years after the shock, on children's health. In addition to the differences of specification dictated by the nature of the research question, our paper differs in the definition of the refugee presence. While Baez district distinction faces measurement errors (see footnote 18 of this paper) and the use of the distance to the Rwandan border may capture refugee-unrelated factors such as the effects of warfare in this neighboring country, our measure of the refugee presence, based on both proximity to and the size of the refugee camps provides a better source of local variation among the surveyed households.

This paper is organized as follows. In the next section, we will describe our case study and list a series of hypothesized effects that have been collected through our

\footnotetext{
${ }^{3}$ Similarly, the closest market used by AlixGarcia and Saah (2008) to assess the effect on prices in the region of Kagera is the one of Bukoba. This small town is located at, at least, 70 kilometers from a small refugee camp and at best, at 145 kilometers (or 4 hours by bus) from the first refugee camp hosting more than 10,000 refugees. There is no doubt that Bukoba is one of the least affected location in our sample.
} 
fieldwork. ${ }^{4}$ Section 3 introduces a theoretical framework aiming at identifying who are likely to gain or suffer the most from the changes induced by the refugee inflows. Section 4 presents the empirical results of our study and discuss the robustness of these results. Finally, we will conclude in section 5 .

\section{Refugee inflows in Kagera}

\subsection{Context}

The Kagera region is a very remote region in North-Western Tanzania. The region is impacted between the Victoria Lake, Uganda, Rwanda and Burundi. Kagera is one of the poorest regions of the country in terms of income per capita with an average of 149,828 Tanzanian Shillings (Tzs, i.e. $166 \$$ a year) per habitant (NBS, 2003). In 2002, about 2 million people lived in a region of 29,241 squared kilometers and mainly rely on subsistence agriculture. One particularity of this region results from its recent history of refugee hosting that makes it an extraordinary "laboratory" to study the impact of refugee inflows on the local population. On the one hand, the magnitude of the phenomenon is a case in point. From October 21, 1993, between 250,000 and 300,000 Burundians fled into Tanzania following the assassination of the President of Burundi. As reported by Rutinwa (2002, 28), a new influx of 250,000 refugees came then from Rwanda from April 28, 1994, within only 24 hours. This influx generated from the crash of the plane carrying the Presidents of Rwanda and Burundi is known as the triggering factor of the Rwandan genocide. This movement, described by the United Nations High Commission for Refugees (UNHCR) as the largest and fastest exodus it had ever witnessed, was followed in the next two months by a number of nearly one million refugees fleeing Rwanda to Tanzania. To put the reader into the picture, in 1995, there remained about 700,000 refugees in the region of Kagera, whose population accounted for about 1.5 million people at that time. ${ }^{5}$ Such a human inflow, representing more than one third of the regional population (even more than one half in Karagwe and Ngara districts), had a financial counterpart. Interviewees stressed the massive flow of money that entered into the local economy through the humanitarian pipeline.

\footnotetext{
${ }^{4}$ The quantitative analysis presented in this paper has been fed by a two-month iterative field research (Udry, 2003). In order to refine some of our hypothesis, about 30 interviews were conducted; data (notably refugee camp location and population) were completed; and some reports were collected to better understand the economic environment of the region and the issues (management, interaction between refugees and local people) related to the refugee presence.

${ }^{5}$ Other refugees also came from the Republic Democratic of Congo from 1997. However, our region of interest, Kagera, did not host these refugees. Congolese camps are mainly located in the neighboring region of Kigoma.
} 
The unanticipated and localized nature of the events provides a tool to isolate the impact of the refugee inflows on the local population from other factors. As witnessed by a local aid worker, "they came very unexpectedly. The local population was never expecting such a thing. Just overnight, so many people were around ... They came like a swarm of loco bees". The unanticipated nature of the events linked to political assassinations is also underlined by AlixGarcia and Saah (2008). Refugees were hosted in city-sized camps. The unexpectedness together with the mass of refugees prevented anyone (government, UNHCR) to direct the refugees to one or more locations across the region that were particularly selected to host the refugees. Given prohibitive costs to transport them, UNHCR and the Ministry of Home Affais (MHA) had to select the locations of the camps within a very small radius. As can be seen in figure 5 and contrary to UNHCR policy, it resulted in camps located very closed to the borders. ${ }^{6}$ While the circumstances for the refugees at these locations were not ideal to say the least, the unpreparedness of the host to find a location for hundreds of thousands refugees removes to a large extent a potential problem of endogeneity. We will discuss further this issue in section 4.3. Furthermore, a change in the refugee policy implemented by the Tanzanian Government restricted the movement of the refugees to 4 kilometers around the camps. ${ }^{7}$ These movement restrictions, coupled with geographical features limiting the spatial spread of the impact (Baez, 2007), provides an exceptional framework to distinguish refugee-hosting areas from others.

\subsection{Observations}

Given the magnitude of the phenomenon, the massive inflow of refugees is likely to have affected the local economy. Based on interviews undertaken on the field in 2008 and secondary sources, the following main impacts have been reported:

- The price of some goods seems to have sharply increased, threatening the food security of some households. The increase of prices should have resulted from

\footnotetext{
${ }^{6}$ Two exceptions appear on the map, i.e. the camps of Burigi and of Mwisa. Both are special "protection camps", populated by only 10,000 refugees in 1995, compared to 200,000 or even 350,000 for the largest camps.

${ }^{7}$ Tanzania has a long history of hosting refugees. In 1972, refugees already fled from Burundi and were directed towards, the so-called old settlements. However, these refugees are very distinct from the 1993-1994 waves. These "old" refugees are not settled into closed camps; were targeted by an "open-door" policy whose aim was to integrate these newcomers (even through naturalization) and ensure self-sustainability of their livelihoods on the Tanzanian territory and were located far from the borders of their country of origin (Rutinwa, 2002). It has to be noted that despite the movement restrictions, 1993-1994 refugees could still receive permission to work outside the camp, provided they came back at night.
} 
an increasing demand from aid workers but also from the refugees themselves. The arrival of international organizations (UNHCR, NGOs) and their staff (local and international) induced a significant increase in demand from people with much higher purshasing power. Food aid could also have had an effect on prices. The World Food Program (WFP), the UN agency in charge of providing food to refugees, could purchase on the local markets. But the main effect came from the refugees themselves. In order to diversify their food diet, refugees exchange the received ratio of maize, maize flour or cooking oil against other products such as bananas, cassava, palm oil, beans, rice, meat, fish, alcohol, etc. Whitaker (1999) reports that about $75 \%$ of the food distributed to refugees were traded. More conservative assessments by WFP gives an estimation of about 20-30\% (WFP and UNHCR, 1998). Refugees also sell non-food items such as blankets and plastic sheets. Such trading activities is easy to observe and even institutionalized by the aid community and the Ministry of Home Affairs (MHA), through the creation of a so-called common market around each refugee camp, where refugees and local people were invited to trade. For example, the common market of Lukole opened between 1994 and 2003 and closed to one of the largest Rwandan refugee camp, is estimated to have been the biggest market of the Kagera region, after the one of the capital town (Bukoba). ${ }^{8}$ Despite these observations, this perceived effect remains an empirical question. As reported by one of our respondents, while the increase in price has been imputed to the refugees arrival, it is difficult to distinguish this increase from the whole issue of inflation in the country.

- One of the most often reported effects is the use of refugees as cheap labor by the local population. Using refugees to till and harvest land, local agricultural production is reported to have in some cases doubled following the refugee arrival, land availability not being a major constraint in Kagera (WFP and UNHCR, 1998). Cheap labour was also used in sectors such as construction, housekeeping or catering. As confirmed by Pr. Rutinwa, refugees were paid below the minimum wage that was about 1000 Tzs a day around that time ... During a focus group he undertook for his study (CSFM, 2003), one woman declared "At least one thing we like about these refugees, they are cheaper.

\footnotetext{
${ }^{8}$ The common market is one of the first institution to be closed by the Tanzanian authorities, when they are planning to close a refugee camp and try to give refugees some incentives to repatriate. It has also to be noted that in a 2001 article on refugees in Western Tanzania, The Economist (Economist, 2001) also witnessed such an increase in demand: "Half a million extra months increase demand for almost everything. The more enterprising locals profit from this, ploughing up extra acres to take advantage of soaring food prices, selling cooking pots and clothes in the camps, and even supplying foreign aid workers with chocolate, cheese and satellite-television dishes".
} 
They are managable in terms of the amount you pay them compared to what you pay a Tanzanian to do the same amount of work". Such an increase in cheap labour should generate a downward pressure on the wages of agricultural workers. Whitaker (1999) reports that the wage paid to casual laborers dropped by about $50 \%$ in many areas. Such a depressing effect on wages for the less skilled is supported by historical evidence provided by Chambers (1986).

- The effect on the wages seems to have been the opposite for the most educated people. As illustrated by one interviewee who used to be chief accountant in a cooperative union when the refugees came in, his salary was below 100,000 Tzs, while the drivers of the international organisations could earn more than 200,000 Tzs. This confirmed the observation by Waters (1999) that salaries in the relief operations were about two to three times the level of salaries for similar positions elsewhere in Tanzania. The resulting increase in the wage of more skilled people is also reported to have attracted employees from other areas. Landau $(2004,45)$ reports that "A district that was once designated as a labour reserve has now become a major destination for Tanzanians from all over the country seeking waged employment with international and nongovernmental organizations."

- Business also seemed to have flourished in the refugee-hosting areas. Whitaker $(1999,7)$ underlines that "With the increased local market, there was an upsurge in business and trade conducted by both local hosts and refugees. Tanzanian entrepreneurs from around the country also flocked to the area. Commercial centers developed in the refugee camps with daily markets and countless shops and restaurants". The economic landscape has completely changed in this respect. Some sleepy (Ngara market, Omukalinsi) or even desert places (Lukole, Benaco, etc) became very active market places. Business seemed to go on even when the refugees repatriate. An aid worker involved in repatriation, underlined how refugees coming originally far away from the Burundian border, repatriate just behind the border to continue their trading activities. The variety of non-agricultural products also seemed to have expanded as "several enterprising Tanzanians even opened shops with catered to expatriate aid workers' tastes for chocolate, cheese, European wines and satellite televisions" (Landau, 2004, 47). This is also the case for local people as some utilities were sold by refugees and new products (cans, etc) entered this very remote area. Despite this boom, the impact on the existing businesses was rather ambiguous. The renewed attractiveness of refugee-hosting areas seems to have gone along with fiercer competition following the entry of other entrepreneurs. 
Such reported increase in competition could have driven some existing petty businesses out of the market. First, a lot of entrepreneurs are reported to have come from Mwanza, Shinyanga and other Tanzanian regions to open a business. People of Haya-origin from Kilimanjaro were often reported as very business-minded and keen to jump on these new business opportunities. As underlined by one active district refugee coordinator in one refugee camp, refugees were also allowed to conduct businesses and were very active in this respect. One of our respondents also pointed to the "unfair" nature of competition, because of the absence of taxes for commodities traded by refugees and the free services provided to them: "it was unfair competition because you cannot compete somebody who has no overhead costs." At the end, the effect on the existing businesses will be an empirical issue.

- Infrastructure seemed to have largely improved following investment made by international organisations in terms of road accessibility. Whitaker (1999, 12) noted that "In Kagera region, more than 15 million dollars went towards the rehabilitation of main and feeder roads, airstrips, and telecommunications infrastructure", making "internal transportation cheaper and easier for host communities". This might be more important that it seemed in a region where the remoteness of the village in which one his born is an important determinant of the likelihood of growing out of poverty (DeWeerdt, 2006).

- Another important reported effect is the improvement of health and sanitation services. If the services were not necessarily available to the local population at the origins of the crisis, the UNHCR and its implementing partners have progressively made these services available to the local hosts. Around $30 \%$ of the health services beneficiaries are reported to be local people. Well, there is no doubt that the standards of these services are very much higher compared to what was delivered to the local population in these very remote areas, before the refugees came in.

- We should also underline the possible destabilizing effects of such population movements. First, the sudden flow of so many people had devastating environmental effect (Berry, 2008). As witnessed by one of our respondents, "When refugees came in, they started to pull down the timber, the wooden materials from the buildings, ... the schools, even the coffee plantations to get firewood". This had dramatic effect, in particular for women, who had to allocate more time to collect firewood, in a region where it constitutes the main source of energy for cooking activities. ${ }^{9}$ Although aid workers con-

\footnotetext{
${ }^{9}$ Since then, one could observe an increased awarness among aid agencies for this issue. Notably,
} 
test it given very tight controls they implement, the spread of desease has been attributed to the coming of refugees living in poor sanitary conditions. At least, regarding wood collection and desease spreading, one could imagine that these effects have been spatially more limited than the economic effects described above (a perimeter of 15-20 kilometers has been reported for the wood destruction around the camps, in the worst cases). Fieldwork also suggests that these effects have decreased overtime following NGO interventions in these respects. Finally, security problems have been reported by officials and police officers. The attribution to the refugees of the security problems has been debated (CSFM, 2003). However, one should, at least, recognize that the inflow of refugees has gone along with a cross-border diffusion of weapons and an increase in criminality (who ever is perpetrating these crimes).

These reported main effects constitute an interesting starting point to understand the complexity of the issue. Nevertheless, we may wonder what are the magnitude, the persistency and the spatial distribution of these effects. First, such narrative evidence does not tell us whether the negative effects are likely to be compensated by some economic benefits. Given the nature of the economic effects, the benefits are also likely to be unevenly redistributed. ${ }^{10}$ As a first approximation, looking at the change of consumption per adult equivalent (PAE, see data description) for all surveyed individuals between 1991 and 2004, the last sticks of the figure 2 suggest that households living closed to refugee camps have increased their consumption PAE but less proportionally than in other areas. But the picture is qualified when looking at poverty groups. ${ }^{11}$ Initially richer people seem to have better seized the opportunities generated by the proximity to refugee camps. They indeed increased their consumption PAE much more (about 38\%) than their counterparts in other areas (about 16\%). On the contrary, the poorest have seen their situation improved

devastated areas around old camps (for example in Karagwe) contrast with more recent Congolese camps in the region of Kigoma where wood collection has been strongly regulated.

${ }^{10}$ Many respondents were quite aware of this inequality effect : " Those who were creative, who were business-minded, they made a lot of money. Even in the villages, those who are farmers, everything produced on the farm, had a market there. For all over the district, it was going there on bycicle, going to get money from the camps. The situation was worst for the most vulnerable groups like the eldery who do not know what to eat next days, those with inability, those with chronic illness but those who were energetic, creative, they made a good money out of it."

${ }^{11}$ Following Collier et al. (1986), we transformed the consumption data of the KHDS data (see data description) by adult equivalent and taking into account price differences between locations. Based on 1991 data, we create four groups, which should reflect the level of poverty in the sample. The identification of people in a village closed to a refugee camp is based on the reply from the community leader to the KHDS question "were there any refugee settlement closed by?". As we will see, more suitable identification criteria are described in section 4.1. 
less $(10 \%)$ than their counterparts in other areas (16\%). Such chart suggests that the Chambers (1986)'s hidden losers can well hide some winners. Second, we do not have any idea about the persistency of the above reported effects. For example, the changes in factor prices (wages, prices of goods, ...) should have been followed by modifications in the consumption and production behaviors. As suggested above, some negative effects (wood devastation, disease risk) may have been reduced overtime. Therefore, section 3 will study in a general equilibrium setting how changes in the good and labour markets will affect differently several agents of the local economy. Finally, we do not only conjecture economic gains to be distributed differently among the refugee-hosting population. Figure 3 also indicates that contrary to the common wisdom considering the presence of refugees uniquely as a burden, the establishment of refugee camp does not either generate more people to get out of the sample (due to untraced migration or death) between 1991 and 2004 or give more incentives to migrate (traced) outside the initial village. ${ }^{12}$ Clearly, the establishment of a refugee camp does not only generate negative externalities. Given the localized nature of the negative effects (environmental degradation, disease, etc), we might then wonder whether the balance between economic benefits and costs differs over space. The existence of a non-monotonic relationship between the proximity to refugee camps and welfare is an empirical question. On the one hand, some respondents were convinced that villages very closed to refugee camps, all in all, suffer from the negative effects, while habitants at intermediate distance could maximize the economic benefits generated by the establishment of refugee camps and minimize the costs. ${ }^{13}$ On the other hand, other respondents clearly reject this non-monotonic

\footnotetext{
${ }^{12}$ Among the 3794 individuals that were interviewed in 1991 and 2004 in our database (therefore, traced when moving from their original village to another village, another region or another country), 2,830 individuals are still living in the same location (75\%) in 2004. The emigration rate computed by village is quite unevenly distributed (from $8 \%$ to $43 \%$ ). What appears rather clear is that the establishment of refugee camps does not seem to have been a big dispersion force. On the contrary, a higher share of the population followed overtime tend to move away from unaffected villages. If the same exercise was performed with the active population, i.e. 1,330 individuals followed overtime, 1011 lived in 2004 in the same village than 10 years ago (76\%). The contrast between refugeehosting communities (17\%) and others (26\%) is even stronger, confirming the slight indication that contrary to common wisdom, the establishment of a refugee camp may well be an attraction force.

${ }^{13}$ In a report drafted in September 1995 (about one year and a half after the arrival of Rwandan refugees) for a local NGO, Adams et al. $(1995,31)$ support such a non-monotonic relationship by stating that "While the whole district has been affected by the arrival of the refugees (through improved transport links, rising prices, loss of livestock, damage of schools and hospitals, the redirection of already over-streched district services to the refugees, an expanding economy, increased opportunities for trade, etc), the negative consequences have tended been very localized. Those villages in the immediate vicinity of the camp have borne the brunt of theft and robbery, the loss of water, fuel and construction materials, threats to household food security, health problems, and social change."
} 
hypothesis. For them, the economic benefits such as health accessibility, outweigh the negative externalities, even for the closest to refugee camps. Given our questions related to the persistency and the distribution of the above effects, the paper will seek to assess, both theoretically and empirically, how the establishment of refugee camps in the region of Kagera has affected the local population in the long run and through which channels. A particular attention will be given in section 4 to allow for a differentiated effect of such establishment over space.

\section{Theoretical framework}

The theoretical framework should help us to identify how agents may adapt to the refugee arrival and the related changes in factor prices. The purpose is to describe how some agents may be able to benefit from the inflow of refugees, while others seem to suffer from it. The below theoretical model will mainly focus on the effects on the labour and good markets. ${ }^{14}$ Controlling for other factors or explanations will be an empirical issue.

We represent a local economy whose population (normalised to one) is composed of $\mathrm{H}$ landed people and L landless people. The landed people are endowned with one unit of land, that can be invested in one of the two sectors of the economy, the agricultural sector or the manufacturing sector (non-agricultural). The landless people are composed of $L_{a}$ agricultural workers and $L_{m}$ manufacturing workers.

\subsection{Preferences}

The preferences of all individuals are represented by Cobb-Douglas preferences, with CES sub-utility for the differentiated non-agricultural goods. The utility of the agent $i$ is composed of its consumption of homogeneous agricultural good A and differentiated non-agricultural goods M.

\footnotetext{
${ }^{14}$ AlixGarcia and Saah (2008) use another framework to understand how refugee inflows affect local prices, through food aid provision. Although interesting, we cannot use a similar framework given our focus on long-run General Equilibrium effects and the distribution of these effects. Our theoretical framework could also be compatible with a New Economic Geography (NEG) extension that would be able to incorporate in a GE setting the change in transportation costs and the mobility of some agents, possibly induced by the refugee inflows.
} 


$$
U_{i}=M^{\mu} A^{1-\mu}
$$

$$
\begin{array}{lc}
\text { with } & M=\left[\int_{0}^{N} q_{m}(s)^{\frac{\sigma}{\sigma-1}} d s\right]^{\frac{\sigma-1}{\sigma}} \\
\text { with } & \sigma>1 \\
\text { s.t. } & G M+p_{a} A \leq Y
\end{array}
$$

$\sigma$ represents the elasticity of substitution between two varieties of the nonagricultural good, while $G$ is the price index of the non-agricultural goods.

From the identical preferences of the individuals, one can obtain the demand functions and we can re-write the price index:

$$
\begin{aligned}
q_{m}(s) & =p_{m}^{-\sigma} G^{\sigma-1} \mu Y \\
q_{A} & =\frac{(1-\mu) Y}{p_{a}} \\
G & =p H_{m}^{\frac{-1}{\sigma-1}}
\end{aligned}
$$

The indirect utility function will be given by introducing the demand functions into the utility function:

$$
\begin{array}{r}
V_{i}=\Theta \frac{y_{i}}{G^{\mu} p_{a}} \\
\text { with } \Theta=\mu^{\mu}(1-\mu)^{1-\mu}
\end{array}
$$

\subsection{Technologies}

The economy is represented with two sectors of production. The agricultural sector performs under constant returns to scale, using one unit of land and $L_{a}$ units of agricultural labor. The non-agricultural sector exhibits increasing returns to scale, with non-agricultural labor as an input. We assume that the price of the agricultural good is equal to 1 .

$$
\begin{aligned}
& \pi_{a}=q_{a}-w_{a} L_{a} \\
& \text { with } \quad q_{a}=L_{a}^{\alpha}
\end{aligned}
$$


The first-order condition gives $w_{a}=\alpha L_{a}^{\alpha-1}$ and $\pi_{a}=(1-\alpha) L_{a}^{\alpha}$. The nonagricultural sector needs $\beta$ variable requirement of skilled labor $L_{m}$ and one landed person, who decides to become entrepreneur. The structure of this sector is the monopolistic competition.

$$
\pi_{m}=p_{m} q_{m}-\beta w_{m} q_{m}-w_{m}
$$

Deriving $\pi_{m}$ with respect to $p_{m}$ gives $p^{*}=\frac{\sigma}{\sigma-1} w_{m} \beta$, i.e. the monopolistic competition result following which the mark-up of price over marginal cost is constant. By the zero profit condition, the equilibrium production is independent of the number of entrepreneurs: $q^{*}=\frac{\sigma-1}{\beta}$. Equalizing this equilibrium production with the demand equation, we obtain the following wage equation, i.e. the wage given to the skilled workers and the rent kept by the entrepreneur:

$$
w_{m}=\frac{\mu L_{a}^{\alpha}}{\sigma H_{m}-\mu\left(L_{m}+H_{m}\right)}\left[\alpha+(1-\alpha) H_{a}\right]
$$

We can show that the non-agricultural wage will be positive provided the number of non-agricultural workers is sufficiently large. Otherwise, the non-agricultural sector does not exist.

$$
w_{m}>0 \quad \text { if } \quad L_{m}>\frac{\sigma-\mu}{\mu(1-\alpha)}(\alpha+(1-\alpha) H)=\widetilde{L_{m}}
$$

This condition will be most easily met if:

- $\sigma$ is low, i.e. the non-agricultural goods are sufficiently differentiated.

- $\mu$ is large, i.e. the constant share of expenditure on non-agricultural goods should be sufficiently large.

- $H$ is low, i.e. the number of landed people should be small enough.

- $\alpha$ is small, i.e. the labor productivity in the agricultural sector should be small enough.

Equalizing $w_{m}$ and $\pi_{a}$ determines the distribution of non-agricultural entrepreneurs:

$$
H_{m}=\frac{\mu\left[\alpha+(1-\alpha)\left(H+L_{m}\right)\right]}{(1-\alpha) \sigma}
$$




\subsection{Theoretical predictions}

Given the fact that $H_{m}$ does not depend on $L_{a}$, a change in landless agricultural workers, which represent the refugee inflow in our present case, can be shown to affect the different agents through two channels: the changes in income and in prices. $V_{a}$, $V_{\pi_{a}}$ and $V_{m}$ denote respectively the indirect utility of the agricultural worker, the landed investing in agricultural activities, the landed becoming a non-agricultural entrepreneur. We assume that given the existence of the non-agricultural sector, $L_{m}>\widetilde{L_{m}}$.

- The agricultural worker suffers from an increase both in competition on the labour market $\left(\frac{\delta w_{a}}{\delta L_{a}}<0\right)$ and in prices following the demand pressure on the good market $\left(\frac{\delta G}{\delta L_{a}}>0\right.$ if $\left.L_{m}>\widetilde{L_{m}}\right)$.

$$
\frac{\delta V_{a}}{\delta L_{a}}=\Theta \frac{\frac{\delta w_{a}}{\delta L_{a}} G^{\mu}-\mu w_{a} \frac{\delta G}{\delta L_{a}}}{G^{2 \mu}}<0
$$

- The landed investing in agricultural activities benefits from an increase in its agricultural rent $\left(\frac{\delta \pi_{a}}{\delta L_{a}}>0\right)$ but suffers from the increase in the price index $\left(\frac{\delta G}{\delta L_{a}}>0\right)$. Given the fact that $H_{m}$ does not depend on $L_{a}$, one can show that the indirect utility has increased following the refugee inflow.

$$
\begin{aligned}
\frac{\delta V_{\pi_{a}}}{\delta L_{a}} & =\Theta \frac{\frac{\delta \pi_{a}}{\delta L_{a}} G^{\mu}-\mu \pi_{a} \frac{\delta G}{\delta L_{a}}}{G^{2 \mu}} \\
\text { Given } V_{\pi_{a}} & =L_{a}^{\alpha(1-\mu)} \frac{(1-\mu)^{1-\mu} H_{m}^{\frac{\mu}{\sigma-1}}(\sigma-1)^{\mu}(1-\alpha)}{\left[\alpha+(1-\alpha) H_{a}\right]^{\mu}(\sigma \beta)^{\mu}} \\
\frac{\delta V_{\pi_{a}}}{\delta L_{a}} & >0 \text { if } L_{m}>\widetilde{L_{m}}
\end{aligned}
$$

- The non-agricultural entrepreneur (also true for the non-agricultural worker) also benefits from an increase of its income but has to support an increase in the price index. However, given the fact that $H_{m}$ does not depend on $L_{a}$ and $L_{a}$ increases $w_{m}$, one can show that the indirect utility of the non-agricultural agent will increase with the number of landless agricultural workers.

$$
\frac{\delta V_{m}}{\delta L_{a}}=\Theta \frac{\frac{\delta w_{m}}{\delta L_{a}} G^{\mu}-\mu w_{m} \frac{\delta G}{\delta L_{a}}}{G^{2 \mu}}
$$

Given $\quad H_{m} \quad$ and $\quad L_{m}>\widetilde{L_{m}} \quad, \frac{\delta V_{m}}{\delta L_{a}}>0$ 


\section{Empirical analysis}

Based on the theoretical predictions, this section seeks to assess the relationship between the refugee inflow and the welfare of the hosting population. Furthermore, we would like to see whether the net costs and/or the net benefits are likely to be unevenly distributed among the refugee-hosting population.

\subsection{Data description}

We use the Kagera Health and Development Survey (KHDS) dataset collected by Economic Development Initiatives (EDI) and the World Bank (Beegle et al., 2006). Based on the World Bank LSMS (Living Standards Measurement Study) standards, the KHDS data provide a very comprehensive survey on several dimensions of the individual and household well-being such as the levels of consumption, income, assets, the occurrence of shocks, but also some community and facilities characteristics such as the availability of public services, the participation to collective groups, etc. In 1991-1994 (4 waves), the KHDS interviewed up to four times 915 households and their members from fall 1991 to January 1994. As illustrated by the stars on figure 4, the households were selected from 51 communities, from the 6 districts of the region of Kagera. In addition to the representativeness of this survey, one interesting feature of this survey is the outstanding exercise of tracing most individuals from the original 915 households, about ten years later, in 2004. Because people had move out from their original households, the KHDS 2004 interviewed about 2,700 households and their members, including those having moved outside their village of origin, the Kagera region and even Tanzania. As indicated by Beegle et al. (2006), the field team achieved an excellent rate of recontact of $93 \%$.

These data are particularly adequate for assessing the impact of the refugee inflows of 1993-1994 on the local population. First, we can be certain that the first wave of the KHDS surveys has been undertaken before October 21, 1993, date of the assassination of the President of Burundi and signaling the start of the refugee crisis in the Kagera region. ${ }^{15}$ Therefore, the data should allow us to distinguish the effect of the refugee inflows from some initial differences between villages, households or individuals. Second, the location of the different villages throughout all the region allows us to introduce a key heterogeneity in our sample, depending on whether the

\footnotetext{
${ }^{15}$ Given the procedure followed to interview a household (i.e. when one household drops it is replaced by a new one starting again wave 1), the facts that the first passage of fieldwork took place between September 1991 and May 1992, that each passage lasts between 6 and 7 months, and that no household was interviewed for the first time in the fourth passage, a household would be interviewed in the first wave in July 1993 at the latest (the majority between September 1991 and may 1992).
} 
individuals are living in a village closed to a refugee camp or not. We use a sample of 3,510 individuals and 812 households (that duplicate into 2126 households by 2004), that have been interviewed in 1991 (before October 21, 1993) and in 2004. ${ }^{16}$

- The dependent variable is computed as the consumption (transformed into log) per adult equivalent, in real 2004 prices. The adult equivalent transformation is applied using the method proposed by Collier et al. (1986) for Tanzania, while the Lapeyres and Fisher indexes are used for price correction. ${ }^{17}$

- The treatment variable should capture the impact of the refugee camp per se. One possibility is to use a dummy variable, denoted RC, indicating whether the community leader has replied positively to the KHDS question "Were there any refugee settlements closed by?". 18 Less vulnerable to reporting errors, our fieldwork allows us to proxy the effect of the establishment of a refugee camp by the distance between any village and the refugee camps as well as the estimated number of refugees by camp (using the 1995 estimates of the refugee population collected through fieldwork and considered as the peak time of the refugee presence). We compute an average of the refugee population weighted by an exponential distance function, called the refugee impact : $R I_{h, v}=\sum_{c=1}^{13} \exp ^{-\alpha d_{v, c}}$ pop $_{c}$, where $c$, from 1 to 13 refugee camp, $\alpha=1$ and $v$ is the village where the household $h$ is living.

- The activity variables define the main occupation of each household. The main occupations introduced are subsistence agriculture, agricultural self-employed , wage employment (distinction between unskilled -farming and fisheries - and skilled labour is made), and non-agricultural self-employment (business and livestock). To determine what is the main occupation of a household, we first compute on the basis of the time spent in a particular activity by each household member and the value of profits or wage realized through this activity, the total income generated by each household and the share of this income

\footnotetext{
${ }^{16}$ To be more precise, from 3796 individuals followed overtime, 254 individuals have been dropped due to missing income data and 32 due to duplication for reasons given in Beegle et al. $(2006,39)$.

${ }^{17}$ The aggregated consumption data provided by EDI (http://www.edi-africa.com) have been used for comparability reasons (recall periods, common definition of components).

${ }^{18}$ It has to be noted that Baez (2007) uses the fact to belong to the districts of Ngara and Karagwe as an identification. We have some concerns about using this indicator as it might rather capture a district-specific unobserved effect rather than the effects of the refugees. First, all villages from Ngara and Karagwe districts do not all report a closed-by refugee settlement. Only eight out of eleven do so. Furthermore, four villages in three neighboring districts also report closed-by refugee settlements. Provided we use the community questionnaire as identification criteria, this would represent 12 villages, i.e. approximately 192 households out of about 816 households or $24 \%$. It represents between 31 and 29 percent of the population in Kagera region.
} 
over the total income generated by this household. We apply the Lapeyres and Fisher index and the adult equivalent method of Collier et al. (1986). ${ }^{19}$ We define a main activity as the one for which the percentage is above the average of the rest of the population. This makes the definition less dependent to an arbitrary threshold (like e.g. larger than one half) but disregard the marginal income sources. ${ }^{20}$ For example, any household generating $99 \%$ of his income from subsistence income and $1 \%$ from business is better to be considered as mainly involved in subsistence agriculture. On the contrary, a household doing more than $15 \%$ of his income (sample average) will be considered as doing business. It also means that one household can have more than one main activity, in case it would specialize into two activities. The activity variables combined with the refugee one will be key to see whether different payoffs are associated with some activities in refugee-hosting areas, compared to other (control) villages.

- Household characteristics are introduced, such as the size of the household, the proportion of literate members, the number of children, the value of land

\footnotetext{
${ }^{19}$ We use the aggregated data given in the 1991-1994 KHDS database and apply the same methods described in KHDS (2004) to compute the 2004 data. For subsistence income, we convert the value of each consumed item according to its amount, its season and its imputed value. The income from self-employed agricultural activities is computed on the basis of the gross revenues minus the costs of household-level activities in farming. Employment income is recognized as the income received as an employee of a private individual or of an institution other than the household, for remuneration in cash or in kind (KHDS, 2004). The household-level value is computed by summing the employment income earned by each member, multiplied by the time this member reports to have worked at each job in the last 12 months. The Laspeyres and PAE transformation have been applied. We replicate the KHDS (2004) method for the year 2004 to compute the non-agricultural self-employed activities. We compute the livestock income by computing the net revenues from livestock. The second method based on reported net revenues and proposed by KHDS (2004) is used. deMel et al. (2009) indeed show that using reported profits provides more accurate measure of profits than the method using (underreported) revenues and expenses. Fishing activities are also added to this category to make 1991 data comparable with 2004 data. One technical problem for the nonagricultural activities appears regarding the way we should treat losses. Indeed as some losses are encountered, some share of income are above 1 or below 0. For 1991, we have about 4 households (or 16 individuals) who have a share of income generated from business above 1, mainly due to losses in the agricultural sector, and about 4 households (or 16 individuals) who have a negative share of income due to business losses. For 2004, the former increases to 92 individuals and the later reduces to one individual. We restrict the negative values to zero.

${ }^{20}$ For another issue (work satisfaction) but a similar choice of threshold, Winkelmann and Winkelmann (1998) also take the sample average as a threshold. 63 households out of 1966 households in our baseline regression did not appear to have any main occupation with this definition. These households have been classified in the subsistence category given the fact they generate the largest part of their income from this activity. However, our results are robust to the exclusion of these households from our regressions.
} 
as the main asset of the household (transformed in PAE and into logarithm).

- As explained below, other variables will be introduced and explain progressively.

Descriptive statistics are given in tables 1 and 2 .

\subsection{Baseline results}

We start by estimating the following regression at the household level, $h$ :

$$
\begin{aligned}
\log \left(V_{h t v}\right) & =\beta_{0}+\beta_{1}\left(R I_{t v}\right)+\beta_{2} A_{c t i v i t y} y_{t v}+\beta_{3} A_{c t i v i t y}{ }_{h t v} * R I_{t v} \\
& +\beta_{4} Z_{h t v}+\beta_{5} \alpha_{t}+\beta_{6} \alpha_{h}+\epsilon
\end{aligned}
$$

- $V_{h t v}$ represents the indirect utility of the household $h$ living in village $v$ at time $t$, measured by the consumption per adult equivalent, correcting for price differences, as explained above.

- $R I$ is the treatment variable, defining the extent to which a household is affected by the refugee inflow. As explained above, we use an inverse distance function (exponential) weighting the 1995 refugee population.

- Activity defines the main occupation(s) of the household $h$.

- $Z$ represents some household characteristics such as the size of the household, the number of children, the proportion of literate members and the stock of land assets.

- $\alpha_{h}$ and $\alpha_{t}$ are respectively a household fixed effect and a time dummy

Like most household panel analysis, we start by restricting our sample of households to the members that have not been traced (excluding new households and/or those that have moved to another location). A household fixed effect is used to reduce the endogeneity risk by controlling for any unobserved time-constant household characteristics, while a time dummy captures any change overtime which is common across all villages. This seems to be particularly important when introducing the activity variables, as unobserved household characteristics might determine the choice of activities and affect the ability of the household to increase his consumption overtime. Like for all our specifications, to correct for heteroskedasticity and correlation of errors within the same district, we use robust standard errors in 
the baseline regressions, by clustering at this level (Bertrand et al., 2004). In column (1) of table 3, we found a non-significant coefficient for the effect of the refugee impact on welfare. In the rest of the table, we found a non-monotonic relationship between the establishment of refugee camps and the dependent variable. We also introduce the activity variables. With the exception of the non-agricultural worker who seems to benefit from the refugee presence, none of our theoretical predictions are supported. ${ }^{21}$ However, these results should be considered with suspicion as they may be threatened by important estimation biases. As in many panel data analysis that do not interview those creating a new household (e.g. children in 1991 that compose a family before 2004), table 3 does not include the split-off households. As explained by Dercon and Shapiro (2007) and Verwimp and Bundervoet (2008), not including the split-off households may create some bias in the estimations. Assume for example, that those who create a new household are younger and more able to adapt to economic changes (eventually induced by the arrival of refugees), you would underestimate the welfare of the original household by only comparing those who still belong to the original household in 1991 and 2004. In other words, a selection bias can be introduced if the split-off households have different characteristics compared with the members of their initial households (Witoelar, 2005). The sample used to compute table 4 includes the split-off households in a household fixed effect framework. To focus on the impact on the local hosts, we exclude, in a first analysis, the households that have migrated outside the region of Kagera between 1991 and 2004. Nevertheless, although they are excluded from the sample, we still need to take into account that these households have changed location. ${ }^{22}$ Otherwise, we could introduce an important omitted variable bias. Migration is indeed known as an important household strategy to smooth consumption overtime (Rosenzweig and Stark, 1989; Stark, 1991) but could also affect other explanatory variables such as the choice of activity. Migration could affect the familly labour cost (e.g. in agricultural activities) or help to enter into some activities thanks to the role of financial

\footnotetext{
${ }^{21}$ In regression (4), like in all the remaining specifications, we test the robustness of our results to the inclusion of (time-varying) village dummies. Results with this dummy should be considered carefully as it results to a re-classification procedure. Out of 994 people who belong to a household which has moved in a village nearby or elsewhere in Kagera, 217 have moved in a known village and could be hence re-classify accordingly. The remaining people moving in unknown village but known district, have been reclassified in a new cluster for each district.

${ }^{22}$ Migration is likely to be an important phenomenon to control for. Collier et al. (1986) already stated that "In Tanzania migration is known to be a phenomenon with a long history which affects a very substantial part of the population." In our sample, we have about 608 individuals out of 3510 individuals who have moved outside their village (or a neighboring village). Interestingly, it is only slightly lower than the more restrictive (outside original village) ratio (27\%) obtained by Collier et al. (1986) with another sample and at another time.
} 
intermediary that could be played by the migrant (Stark, 1980; Taylor and Wyatt, 1996). Table 4 introduces the proportion of the initial household members who have moved outside the region of Kagera (either in Tanzania or in Uganda) as well as the household decision to move outside the village of origin and its neighborhood within the Kagera region. Working with panel data, we complete these variables by the reported history of past migration of the household (proportion of migrants reported in 1991). Nevertheless, the migration variables could be endogenous due to simultaneity or omitted variable problem. As usual in migration studies, you need to clarify the causal link between the change in welfare and the migration decision. In other words, you do not know whether the decision to migrate is explained by the change in consumption or some unobserved characteristics (skills, motivations, etc) of the household or the opposite. Therefore, we use instrumental variables to deal with the endogeneity of the migration decisions. Similar to Scott Rozelle and deBrauw (1999), we construct an instrumental variable, capturing the spillover effect at the village level, i.e. the number of migrants by village but excluding the ones of the concerned household. We also compute the past value of this instrument, using 1991 data. Regarding the decision to migrate within the region of Kagera, we also use the proportion of the initial household migrating, excluding the concerned household to keep this instrument exogenous to the decision to move itself. Table 5 shows the first-stage fixed effect regressions. As expected, the measurements of migration spillovers positively affect our migration variables, with a highly significant F-test. The Anderson Correlation LR statistics rejects the null hypothesis of underidentification, while given the Stock and Yogo (2005) statistics, we can strongly reject the null hypothesis of weak instruments. Given the Hansen overidentification test, we cannot reject the null hypothesis that our instrumental variables are valid. 23

Regression (1)-(4) of table 4 use the sample that includes the split-offs and the migration variables, without instrumental variables. We turn to regressions (5)-(8) that deal with the potential endogeneity of the migration variables. Regression (5) of table 4 at least indicates that, when split-off households are included and contrary to common wisdom, the establishment of refugee camps does not only release negative externalities on the local population. The impact is rather small but still is on average significant and positive. An increase by a standard deviation of the RI index would on average increase the consumption per adult equivalent by about only 1\%. That is being said, our results also shed light on the two hypothesis that had

\footnotetext{
${ }^{23}$ We had to partial out some variables to test the validity of our instruments. Our procedure was first to check if our coefficients and standard errors remain unaltered when partialling out the household-specific variables (size, proportion of literate members and the value of land holding) and then, correct the covariance matrix to make such tests feasible.
} 
been formulated in the previous sections. First, our theoretical framework suggests that the effects on the good and labour markets are likely to be unevenly distributed among the local population. Therefore, we introduce the activity variables defined in section 4.1. Results should be compared to households whose main occupation is subsistence agriculture and who are likely to be the least affected by the refugee impact on the labour and good markets. Very consistently throughout our various specifications, those involved in agricultural activities as self-employed farmers appear to be better-off by the refugee presence, compared to their counter-parts in other areas. Among the winners, are also to be found the workers in non-agricultural activities. Such result is consistent with the evidence that skilled workers have been relativelly better valued by NGOs and international organizations in refugee-hosting areas. One of the most negatively affected by the refugee camps seems to be the agricultural worker, likely to face fiercer competition on the labour markets and increased prices for his purchases. An increase by a standard deviation of the RI index (at average level) would deteriorate the welfare of the agricultural worker by about 8-10\% (see columns (3) and (4) of table 13). Despite the reported boom in this sector, our results suggest that those involved in business activities would experience a welfare deterioration following a similar change of the RI index of about 10-12\% (see table 13). One possible explanation is the reported increase in competition in the business sector, following the arrival of more productive entrepreneurs from other regions (given the tracing nature of our data, newcomers are not included in our sample) who would have driven the existing local businesses out of the market. Although not treated specifically in the theoretical model, those involved in livestock are better-off. ${ }^{24}$ Such positive effect is not only explained by the increased demand both from refugees and non-governmental organizations but mainly by a disruption of the supply of livestock at the time of the refugee arrival. In a mission identification report, the World Food Program (Program, 1995, 4) describes the evolution of the livestock sector in the two districts that have massively hosted refugees : "Livestock is widespread everywhere but only in some areas were large cattle established after independence with the arrival of Tutsis refugees from Rwanda, who brought their herds with them. In 1984, in Ngara, around 18,000 head of cattle were recorded and 128,000 in Karagwe ... As a result of refugees influx, about 50\% of the cattle population in some major livestock keeping villages of Ngara district were taken out of the country when the Tutsis decided to return to Rwanda after the RPF government took power there, leaving Ngara and Karagwe with only about 8,000 and 65,000 cattle respectively."

\footnotetext{
${ }^{24}$ Those activities were merged with the business activities in previous works. The same results than the ones provided for the business activities were found.
} 
Among the household control variables, the positive and negative coefficients of respectivelly the proportion of literate members within the household and the size of the household need to be underlined. As expected, being a split-off household also positively affect the household welfare. Consistently with Beegle et al. (2007), table 4 also shows that the correlation between welfare and migration is only attributed to unobserved household characteristics that determine the migration decisions. Finally, our fieldwork helps us to hypothesize a non-monotonic relationship between the refugee impact and welfare. We found some first indications of a U-shaped relationship between RI and the dependent variable. Nevertheless, it appears to be the reverse than the one that was expected. Our results suggest that the closer you are or the biggest the refugee population is, the more you benefit from it. By contrast, at some distant point or below a certain level of refugee population, you might suffer from the refugee presence. In the section 4.3.2, we will discuss further how we could understand the roots of this potential non-monotonic relationship.

\subsection{Discussion and robustness}

\subsubsection{Robustness}

We have imposed a particular structure to our baseline specification by adopting a household fixed effect specification and by restricting our sample to those household members who have not migrated outside the region of Kagera. First, the use of a household fixed effect imposes the assumption that the split-off households become independent from its initial household. A different assumption would be that the split-off households are altruist vis-à-vis their family and therefore, pool all their income and their consumption with their initial household. Altonji et al. (1992) and Witoelar (2005) propose a method to actually test the altruist hypothesis. Using an initial household fixed effect, an altruist household would result in a distribution of consumption per adult equivalent within the extended family independent of the distribution of income (net of remittances). Table 6 strongly rejects the null hypothesis of altruism among households of our sample, as the income net of transfers positively affects the consumption per adult equivalent when controlling for an initial household fixed effect and other time-varying household-caracteristics. This result holds, using different samples and different instrumental variables to deal with the potential endogenity of the income variable. ${ }^{25}$

\footnotetext{
${ }^{25}$ More information is given in the explanatory note of table 6 . For comparability reasons, we first use in regressions (1) and (2) the instruments proposed by Witoelar (2005), i.e. the value of land, of farm productive equipments and of non-farm productive assets. However, we have some doubts about the exogenous nature of these instrumental variables. Said differently, we might suspect these variables to affect the consumption variable, by another channel than the income effect. Therefore,
} 
Second, one concern might be related to the way migratory flows would affect our results. On the one hand, a catastrophic view on the refugee crisis might suspect that the coefficient of the RI index is overestimated because of an attrition problem. In other words, if local people tend to die (e.g. due to disease) or escape the refugeehosting areas (without being traced), our results might only reflect the change of welfare of those better equipped to face such a shock. However, given the lower attrition and emigration rates depicted in chart 5 , we can rule out this possibility. On the other hand, the opposite might also be true. The magnitude of our coefficients might be underestimated, as the mobility of some agents would tend to reduce the magnitude of the impact, notably through economic activities. Although section 1 gives clear reasons for the localized nature of the refugee impact, our estimates can then be considered as a lower-bound of the real impact. We also remind that in order to reduce this bias, we control for migration variables. As a robustness check, table 7 considers a sample that would include those who have migrated. In this case, we change the migration variables by introducing dummies indicating directly whether the household head has decided to migrate outside the region of Kagera. Table 7 confirms our main results. ${ }^{26}$ Third, table 8 tests whether our results capture longlasting effects. Indeed, we use the fact that refugees from Burundi and Rwanda differ in their duration of stay in Tanzania. Refugees from Rwanda have indeed been repatriated in 1996 while the last refugees from Burundi left the region of Kagera in July 2008. Although we should remain cautious about the interpretation of this table ${ }^{27}$, the effects of the refugee presence appear to be long-lasting, with the exception of the direct effect. The next section will help us to better understand the interpretation to be given to this direct effect.

we introduce the distance through road networks to the main trading partners as an instrumental variables. The first-stage regressions are also provided in table 6. Such instrumental strategy is applied to both samples, excluding or including the households migrating outside the region of Kagera.

${ }^{26}$ The overidentification test sheds some doubts on the validity of the instruments in this setting. When the migrants are included, we actually use an additional instrumental variable, which is the corrected proportion of migrants of the initial household. The rejection of the test backs our preferences for a model excluding migrants, while controlling for migration within the households. Second, this could provide an indication that migration may result from an enlarged household strategy and therefore, could affect the dependent variable through another channel than the potential endogenous variable, when migrants are included. Coping strategies adopted in a refugee-hosting context is a subject of further research.

${ }^{27}$ We keep this distinction as a robustness checks, because we are likely to capture unobserved differences between refugees from Rwanda and Burundi. For example, the environmental degradation is reported to have been much fiercer in Rwandan refugee camps, while such degradation has been much more under control in more recent Burundian camps. On the contrary, refugees from Rwanda were reported to be much more skilled or hard-working. 
Finally, a legitimate concern might be related to the exogenous nature of the location of the camps. In other words, one could worry that the location of the camps would be linked to unobserved village caracteristics. For example, Baez (2007, 12) argues that "poorer regions that are highly disadvantaged in some unobservable domains may be relatively more likely to [...] host more refugees (e.g. limited institutions and systems to control their arrival or assist them). If that is the case, any association between the number of refugees and welfare measures of domestic inhabitants will likely be driven by the underlying correlation between the level of development of host regions and these two outcomes rather than by the causal effect of the exposure to refugees." On this point, we disagree with Baez (2007). First of all, controlling the border was not at all something in the hands of the local authorities. The refugee inflow was so massive that at that time, it was before all a security issue and borders were of the military resort. The choice of location was mainly taken by the Ministry of Home Affairs and UNHCR. Among the criteria reported to have been used, there was an important cost issue. As described in the contextual section of this paper, the refugee inflow was the largest in UNHCR history and highly unanticipated. In October-November 1993, the influx of refugees was so sudden that refugees stayed closed to local communities, without formal assistance up to April 1994. They were so numerous that it was reported to be too costly to move them far away from the border. Therefore, contrary to the UNHCR handbook of Emergencies and international law recommendations, refugee camps were located pretty close to the border. So, if there was a choice of location to be made, this choice was restricted in the area close to the border. In addition, as confirmed by officials, this was reinforced by the willingness of the Tanzanian government to ease the repatriation process and reduce as quick as possible the risk to create a small Rwandan or Burundian conflict within the Tanzanian borders. Such geographic restrictions on the choice of location certainly reduce the endogeneity problem. Our identification strategy indeed rests on the fact that there was no choice of location between far away and close villages. Regressing the RI index on the 1991 values of the explanatory variables and the consumption per adult equivalent, table 9 (part A, columns 1 and 2) even shows that the refugee presence is not significantly related to 1991-defined characteristics. Furthermore, given the fact the choice of location was constraint in the border areas due to transport cost issue, we repeat the same exercise, restricting the sample to Ngara and Karagwe, the two border districts. The part B of table 9) indicates that the RI index is not statistically related to 1991 explanatory variables. 


\subsubsection{Interpretation : Scale versus spatial effect?}

Based on our baseline estimation (table 4), we have already pointed that the establishment of refugee camps (more exactly, a positive change of a standard deviation at an average RI) has on average a positive and significant impact of less than $1 \%$ on welfare. This is a very small impact but we found a very differentiated effects on the local population. The main winners seem to be the skilled workers that enjoy increased job opportunities and the self-employed farmers who could benefit from a very cheap labour force. However, using the most robust results (columns (7) and (8) of table 4), columns (3) and (4) of table 13 qualify this finding. In net terms, the non-agricultural worker will benefit from the refugee presence, only if he is very close to a refugee camp and if the refugee population is very large. At an average value of the RI index, its welfare will slightly decrease following an increase by a standard deviation of this index while at the maximal value of the index (i.e. the closest village or the most populated refugee camp), he will improve his situation by a percentage of $11-12 \%$. A similar qualification applies to another winner, the self-employed farmer. On the contrary, the main losers, i.e. the agricultural worker and those involved in business will experience a deterioration of their welfare (in a range of about $10-12 \%$ at the average $\mathrm{RI}$ index) but this negative effect will also be softened, the closer they are located to a refugee camp or the more numerous the refugee population is. Such qualified interpretation comes from the non-monotonic relationship found between the RI index and the welfare of the local population. Table 13 indicates that the minimum of the U-shaped relationship found between the RI index and the dependent variable is low but stands within the range of possible values. Independently of the main occupations of the households, a variation of the standard deviation of the RI index (at the average level) would decrease consumption per adult equivalent by about $4-6 \%$, while at the closest and/or the most refugee-populated village, it could increase consumption by about $7-8 \%$.

Despite this above interpretation, the non-monotonic relationship between the RI index and the dependent variable does not necessarily receive easy interpretation. Indeed, one does not know whether the relationship is driven by its spatial component (proximity to refugee camps) or its scale component (size of the refugee population). One possible approach is to introduce alternative treatment variables to be able to decompose a scale effect from a spatial one. Tables 10 and 11 introduce four alternative variables of interest. Columns (1) to (3) of table 10 use the simple dummy variable indicating whether the community leader replies positively to the question "Were there any refugee settlement close by?". Such variable is not significant and is likely to be very noisy given possible reported and measurement errors. Regressions (4) to (6) restrict the computation of the RI index for each village to the 
closest refugee camp. Our previous results are confirmed with similar coefficients. Such simplification allows us to decompose the RI index for the closest camp into a scale and a spatial dimension. Table 11 presents the results. The spatial dimension seems to keep a similar non-monotonic relationship. However, the minimum stands largely above the range of possible values. On the contrary, the effect through economic activities, seems to be well captured by the spatial decay function. The opposite is true for the scale dimension. The non-monotonic relationship is confirmed, while the effects through economic activities are less precisely captured. The next step is then to introduce simultaneously the two dimensions, like in table 12 . We have a confirmation that it is the scale dimension which is driving the non-monotonic shape. Such a result might seem surprising but this suggests that a minimum mass of refugees is needed to generate positive externalities that would benefit the local population (independently of the main economic occupations). Looking at the minimum of the U-shaped relationship, table 13 indicates that this minimum mass could amount to about 72,000 refugees. Such a figure should be considered with a great degree of cautiousness. For us, it does not contradict the UNHCR recommendations to its own staff that in general, "large camps of over 20,000 people should generally be avoided" (UNHCR, 1982) because of possible problems of accommodation, security, etc. We indeed do not consider these internal constraints to the size of a refugee camp. However, our results could suggest that in this approximation of the optimal size, UNHCR should internalize the effect of the size on the local hosts, which is not necessarily as expected. A smaller size is not unavoidably optimal. For the activity variables, the scale dimension is only relevant for the agricultural sector for which the number of refugees would determine the size of the workforce. The spatial dimension also seems to describe a non-monotonic relationship, i.e. an inverted U-shaped function, backing our fieldwork hypothesis that very closed village would suffer the most from negative externalities. Nevertheless, the maximum point stands again outside the range of possible values (276.7 corresponding to about 32.5 kilometers). being on the right-hand tail of the inverted $\mathrm{U}$, such result tends to suggest that despite the existence of negative externalities, the closer you are, the best it is for your welfare. Furthermore, the spatial dimension explains very much the effects on the non-agricultural sector. Contrary to the agricultural sector very sensitive to the number of refugees, the fiercer competition exerted on the business sector and the increased job opportunities for non-agricultural workers appear to be very localized around the refugee camps. Finally, the discussion on the potential endogeneity of the RI index could be extended to the alternative refugeerelated variables introduced in this section. As can be seen in table 9 , the same conclusions on the exogenous nature of the camp location apply. An exception is 
raised for the scale dimension when the sample is restricted to the border districts. Larger refugee camps are associated with lower consumption per adult equivalent and fewer households holding non-agricultural labour as a main occupation. Therefore, the average positive estimate should be rather considered as a lower bound if one assumes that this association is not random. To sum up, the unexpectedness and the magnitude of the inflow coupled with the unpreparedness of the Tanzanian and international authorities to the refugee inflows make us confident to deal with a solid quasi-experiment. Still, even if one doubts about the endogenous nature of the refugee camps, statistical evidence also suggests it would only impose a lower bound on the welfare-improving effect of a larger refugee camp.

\section{Conclusions}

Following an iterative fieldwork that helps us to clarify some hypothesis, the paper sheds some light on the impact of refugee inflows on their local hosts. Contrary to conventional wisdom, we found on average a slightly positive impact on local people welfare. However, such an impact appears to be highly differentiated among the refugee-hosting population. The agricultural worker suffered from fiercer competition on the labour markets and increased prices on the good markets in refugeehosting areas. On the policy side, programs (e.g. education, microfinance, etc) might target those agricultural workers to help them to cope with such a shock on the local economy. On the contrary, those involved in agricultural activities as self-employed farmers, have benefited from the supply of a cheap labour force while the worker in the non-agricultural sector tends to have improved their situation (as skills have been highly valued by NGOs and international organizations). In disagreement with our theoretical prediction, the self-employed in business activities does not seem to have improved its welfare, on the contrary. Such results contrast with the business boom reported by interview respondents during our fieldwork. Possible reconciliations might call for integrating an increase in competition (with selection effect) into our theoretical framework. Understanding the factors affecting the entry and exit into such activities is certainly a subject for further works and could path the way for more policy-oriented conclusions aiming at easing the adoption of coping strategies by the local population following such a refugee inflow.

Furthermore, our empirical analysis rejects the hypothesized non-monotonic relationship according to which negative externalities (environmental degradation, security issues, disease spread, etc) would overcome the economic benefits in villages much more affected by the refugee presence. On the contrary, we found the opposite relationship : the closer you are or the more populated the refugee camp is, the more 
likely you could benefit from positive external effects (even when controlling for the impact on economic activities). By investigating further this U-shaped relationship between the refugee presence and the consumption per adult equivalent, we found that a minimum mass of refugees could be needed for these positive externalities to materialize. Research is currently undertaken to explore how the provision of local public goods and the concentration of economic activities around the refugee camps could explain this scale effect on welfare. Understanding the nature of these findings could lead to a radical change of paradigm regarding the impact of refugees on the local population. Along with minimizing the negative externalities, improving the capabilities of the local people to cope with such a structural change and eventually, integrating progressively these refugees into the local economy, the presence of refugees could actually constitute a unique asset (rather than a burden) to break down some traps of underdevelopment.

\section{Acknowledgements}

The first author is grateful to the Center for the Study of Forced Migration (University of Dar es Salaam), Joachim De Weerdt (EDI) and Jonathan Wosley, UNHCR (in particular Yacoub El-Hillo and Eveline Wolfcarius), WFP (in particular Taban Lokonga), several NGOs and many other respondents for the support received during fieldwork activities. We are indebted to all interview respondents for the time they accepted to dedicate to our research. The first author also acknowledges financial support from the Fonds National de la Recherche Scientifique (FNRS) and from the Communauté Française (Bourse de voyage 2008).

We are also grateful to Paola Conconi, Joachim De Weerdt, Fernanda Estevan, Miren Lafourcade, Luca Marchiori, Walter Steingress, Jacques Thisse as well as participants to PAI meeting (13 Octobre 2008, Bruxelles), ECRU seminar (21 November 2008, Louvain-la-Neuve), the fourth annual HiCN conference (5 December 2008, Yale University, New haven), the International Conference on New Economic Geography (13 December 2008, Passau University), the UCL DW (22 January 2009, Louvain-la-Neuve), the second CEPR conference on "Transnationality of Migrants" (23 January 2009, LLN), the EUDN Workshop in development economics (21 March 2009, Oxford), the CSAE conference 2009 on economic development in Africa (24 March 2009, Oxford) and the Economic Lunch Seminar (20 April 2009, Antwerp) for useful comments. We are indebted to the World Bank and Kathleen Beegle for granting access to confidential geographic data of the Kagera Health and Demographic Survey (2004).

This text presents research results of the Belgian Program on Interuniversity Poles of Attraction initiated by the Belgian State, Prime Minister's Office, Science Policy Programming. The scientific responsibility is assumed by the authors. 


\section{References}

Adams, M., Samuel, V., Sekiku, J., and Tibandebage, F. (1995). The impact of the rwandese influx on tanzanian villages. karagwe district, kagera region. tanzania. ACORD (Agency for Cooperation and Research in Development) Report of a Field Visit 20 August - 7 September 1995 .

AlixGarcia, J. and Saah, D. (2008). The effect of refugee inflows on host communities: Evidence from tanzania. unpublished manuscript.

Altonji, J. G., Hayashi, F., and Kotlikoff, L. J. (1992). Is the extended family altruistically linked? direct tests using micro data. The American Economic Review, 82(5):1177-1198.

Azam, J.-P. and Hoeffler, A. (2002). Violence against civilians in civil wars : Looting or terror. Journal of Peace Research, 39(4):461-485.

Baez, J. E. (2007). Civil wars beyond their borders: The human capital and health consequences of hosting refugees. Job market paper.

Barret, C. B. (2002). Food aid and commercial food trade. OECD Background paper.

Beegle, K., DeWeerdt, J., and Dercon, S. (2006). Kagera health and development survey 2004 basic information document. mimeo. The World Bank.

Beegle, K., DeWeerdt, J., and Dercon, S. (2007). Poverty and wealth dynamics in tanzania: Evidence from a tracking survey. In Narayan, D. and Petesch, P., editors, Moving out of Poverty, page forthcoming in volume 2. Palgrave MacMillan and The World Bank.

Berry, L. (2008). The impact of environmental degradation on refugee-host relations: a case study from tanzania. UNHCR EPAU Research paper, 151.

Bertrand, M., Duflo, E., and Mullainathan, S. (2004). How much should we trust differencesin-differences estimates. Quarterly Journal of Economics, 119(1):249-275.

Borjas, G. (1999). The economic analyses of immigration. In Ashenfelter, O. and Card, D., editors, Handbook of labour economics, volume 3A. North Holland.

Bubb, R., Kremer, M., and Levine, D. (2007). The economics of international refugee law. mimeo.

Card, D. (1990). The impact of the mariel boatlift on the miami labour markets. Industrial and Labor Relations Review, 43(2):245-257.

Chambers, R. (1986). Hidden losers? the impact of rural refugees and refugee programs on poorer hosts. International Migration Review, 20(2):245-263. Special issue: Refugees: Issues and directions.

Collier, P., Radwan, P., Wangwe, S., and Wangwe, A. (1986). Labour and poverty in Rural Tanzania. Oxford University Press and ILO, Oxford. 
Crisp, J. (2003). No solution in sight : The problem of protracted refugee situations in africa. Center for Comparative Immigration Studies Working Paper 68.

CSFM (2003). The impact of the presence of refugees in northwestern tanzania. Center for the Study of Forced Migration. University of Dar es Salaam.

de Montclos, M.-A. P. and Kagwanja, P. M. (2000). Refugee camps or cities? the socioeconomic dynamics of the dadaab and kakuma camps in northern kenya. Journal of Refugee Studies, 13(2):205-222.

deMel, S., McKenzie, D. J., and Woodruff, C. (2009). Measuring microenterprise profits: Must we ask how the sausage is made? Journal of Development Economics, 88(1):19-31.

Dercon, S. and Krishnan, P. (2004). Food aid and informal insurance. World Bank Policy Research Working Paper, 3217.

Dercon, S. and Shapiro, J. S. (2007). Moving on, staying behind, getting lost: Lessons on poverty. mobility from longitudinal data. In Narayan, D. and Petesch, P., editors, Moving out of Poverty, volume 1, chapter 3, pages 77-126. Palgrave MacMillan and The World Bank.

DeWeerdt, J. (2006). Moving out of poverty in tanzania's kagera region. EDI Working Paper.

Donovan, C., McGlinchy, M., Staatz, J., and Tschirley, D. (2006). Emergency needs assessments and the impact of food aid on local markets. MSU International Development Working Paper, 87.

Economist, T. (2001). The penalty of kindness. The Economist, 23 August 2001.

Hatton, T. J. and Williamson, J. G. (2004). Refugees, asylum seekers and policy in europe. NBER Working Paper 10680.

Hunt, J. (1992). The impact of the 1962 repatriates from algeria on the french labor market. Industrial and Labor Relations Review, 45(3):556-572.

KHDS (2004). User's guide to the kagera health and development survey datasets. Development Research Group. The World Bank.

Kuhlman, T. (2002). Responding to protracted refugee situations. A case study of Liberian refugees in Côte d'Ivoire. UNHCR Evaluation and Policy Analysis Unit.

Landau, L. B. (2004). Challenge without transformation: refugees, aid and trade in western tanzania. Journal of Modern African Studies, 42(1):31-59.

NBS (2003). Kagera region socio-economic profile. National Bureau of Statistics of Tanzania and Kagera Regional Commissioner. dar es Salaam.

Ottaviano, G. and Peri, G. (2006). Rethinking the effects of immigration on wages. NBER Working Paper 1249\%. 
Program, W. F. (1995). Refugee affected areas development project. identification/formulation mission report. World Food Program Report No: 85/95 TCP-URT 5810 August 1995.

Rosenzweig, M. R. and Stark, O. (1989). Consumption smoothing, migration, and marriage: Evidence from rural india. Journal of Political Economy, 97(41):905-926.

Rutinwa, B. (2002). The end of asylum? the changing nature of refugee policies in africa. Refugee Survey Quarterly, 21(1-2).

Scott Rozelle, J. E. T. and deBrauw, A. (1999). Migration, remittances, and agricultural productivity in china. American Economic Review, 89(2):287-291.

Slaughter, A. and Crisp, J. (2009). A surrogate state? the role of unhcr in protracted refugee situations. UNHCR EPAU Research Paper 108.

Stark, O. (1980). On the role of urban-to-rural remittances in rural development. Journal of Development Studies, 16:369-374.

Stark, O. (1991). The migration of labor. Cambridge (USA): Basil Blackwell.

Stark, O. (2004). On the economics of refugee flows. Review of Development Economics, $8(2): 325-329$.

Stock, J. and Yogo, J. H. (2005). Testing for weak instruments in iv regression. In Stock, J. H., editor, Identification and Inference for Econometrics Models: A Festschrift in Honor of Thomas Rothenberg, pages 80-108. Cambridge University Press.

Taylor, J. and Wyatt, T. (1996). The shadow value of migrant remittance, income and inequality in a household farm economy. Journal of Development Studies, 32(6):899-912.

Udry, C. (2003). Fieldwork, economic theory and research on institutions in developing countries. unpublished.

UNHCR (1982). Handbook for emergencies. UNHCR memo.

UNHCR (2007). 2007 global trends. refugees, asylum-seekers, returnees, internally displaced and stateless persons. United Nations High Commission for Refugees.

Verwimp, P. and Bundervoet, T. (2008). Consumption growth, household splits and civil war. HiCN-Households in Conflict Network Working Paper 48.

Waters, T. (1999). Assessing the impact of the rwanda refugee crisis on development planning in rural tanzania 1994-1996. Human Organization, 58(2):142-152.

Werker, E. (2007). Refugee camp economies. Journal of Refugee Studies, 20(3):461-480.

WFP and UNHCR (1998). Household food economy assessment greater lukole camp. ngara district tanzania. World Food Program/United Nations High Commission for Refugees Joint assessment 10 July- 12 August 1998. 
Whitaker, B. E. (1999). Changing opportunities: refugees and host communities in western tanzania. Journal of Humanitarian Assistance, pages 1-23.

Winkelmann, L. and Winkelmann, R. (1998). Why are the unemployed so happy? evidence from panel data. Economica, pages 1-15.

Witoelar, F. (2005). Inter-household allocations with extended families: Evidence from the indonesia family life survey. Economic Growth Center Discussion Paper. Yale University, 912. 


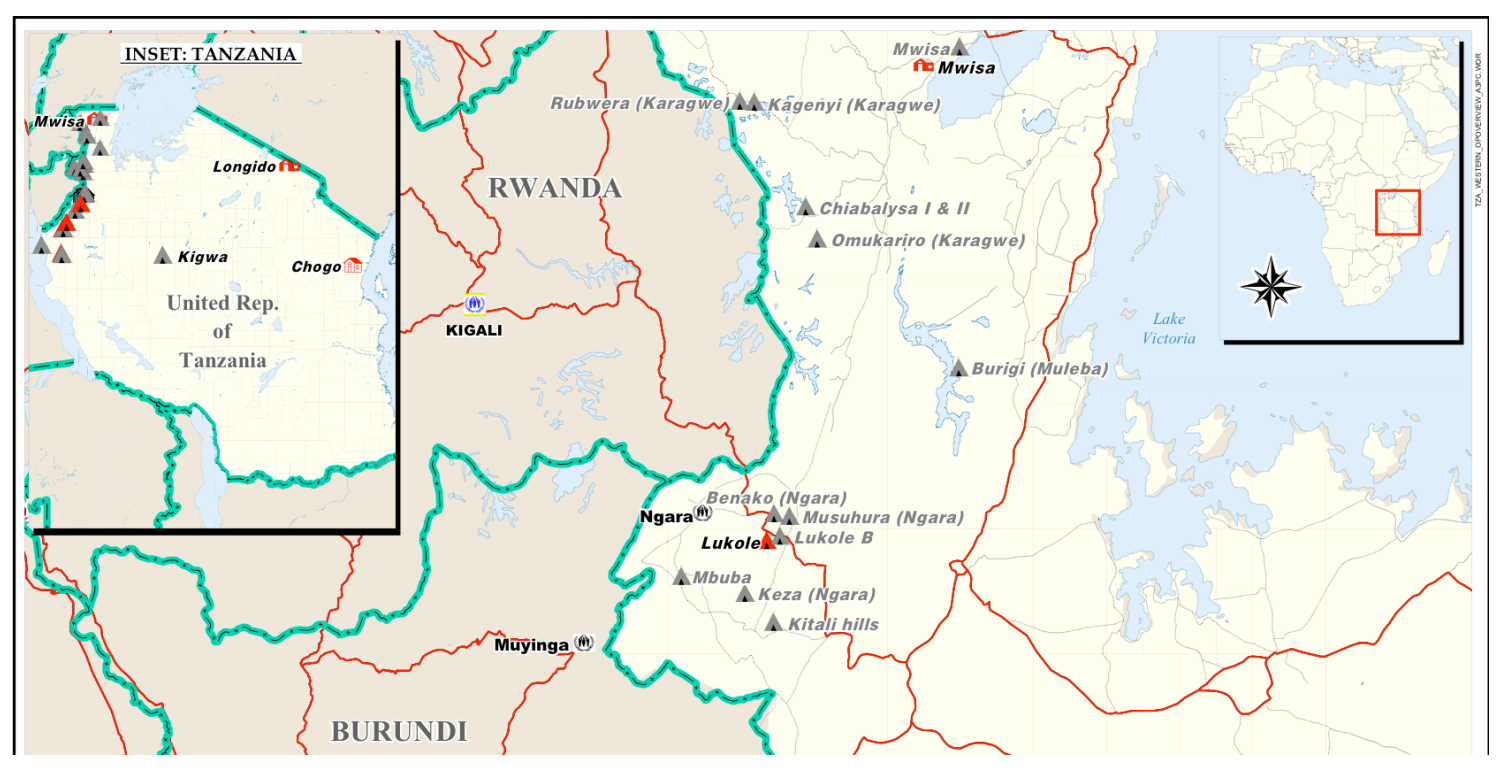

Figure 1: UNHCR Regional Spatial Analysis Lab (Nairobi) and fieldwork geographic coordinates

Table 1: Descriptive statistics for panel data (village-specific data)

\begin{tabular}{|l|c|c|c|c|c|}
\hline Variables & Obs & Mean & Std. Dev. & Min & Max \\
\hline RI & 4252 & 2.970049 & 24.95085 & 0 & 261.4514 \\
\hline RI(Burundi) & 4252 & 2.970049 & 24.95085 & 0 & 261.4514 \\
RI(Rwanda) & 4252 & $2.79 \mathrm{e}-07$ & $3.11 \mathrm{e}-06$ & 0 & .0000349 \\
\hline RC & 4252 & .1298213 & .3361462 & 0 & 1 \\
RI(closest) & 4252 & 2.897639 & 24.2017 & 0 & 253.3578 \\
exp $\left(d_{v, \text { closest }}^{-1}\right)$ & 4252 & .0000304 & .0002136 & 0 & .0021113 \\
Population(ref) & 4252 & 7299.906 & 22951.92 & 0 & 120000 \\
\hline
\end{tabular}

$R C$ is a dummy variable indicating whether the community leader has replied positively to the question "Were there any refugee settlements closed by?"; RI(closest) applied the same average of the refugee population weighted by an exponential distance function; $d_{v, \text { closest }}^{-1}$ is the inverse exponential distance function between each village and the closest refugee camp; Refugees(closest) is the number of refugees in the closest refugee camp. 
Figure 2: Change in consumption per adult equivalent, by initial poverty groups

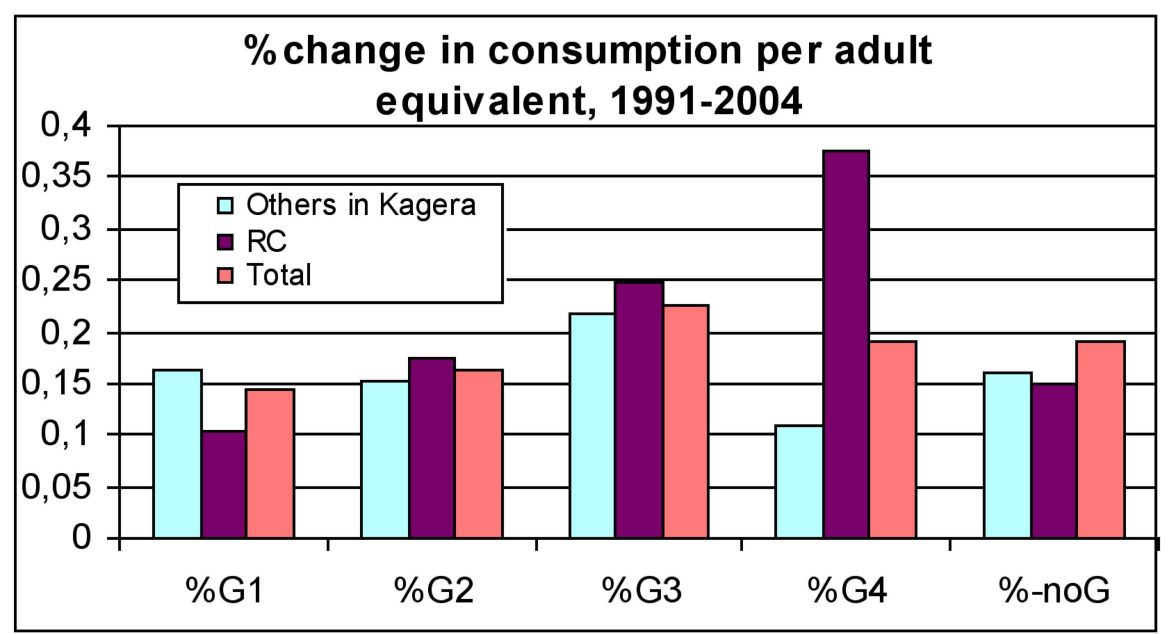

Figure 3: A refugee camp is not only a dispersion force (Own calculation based on KHDS)

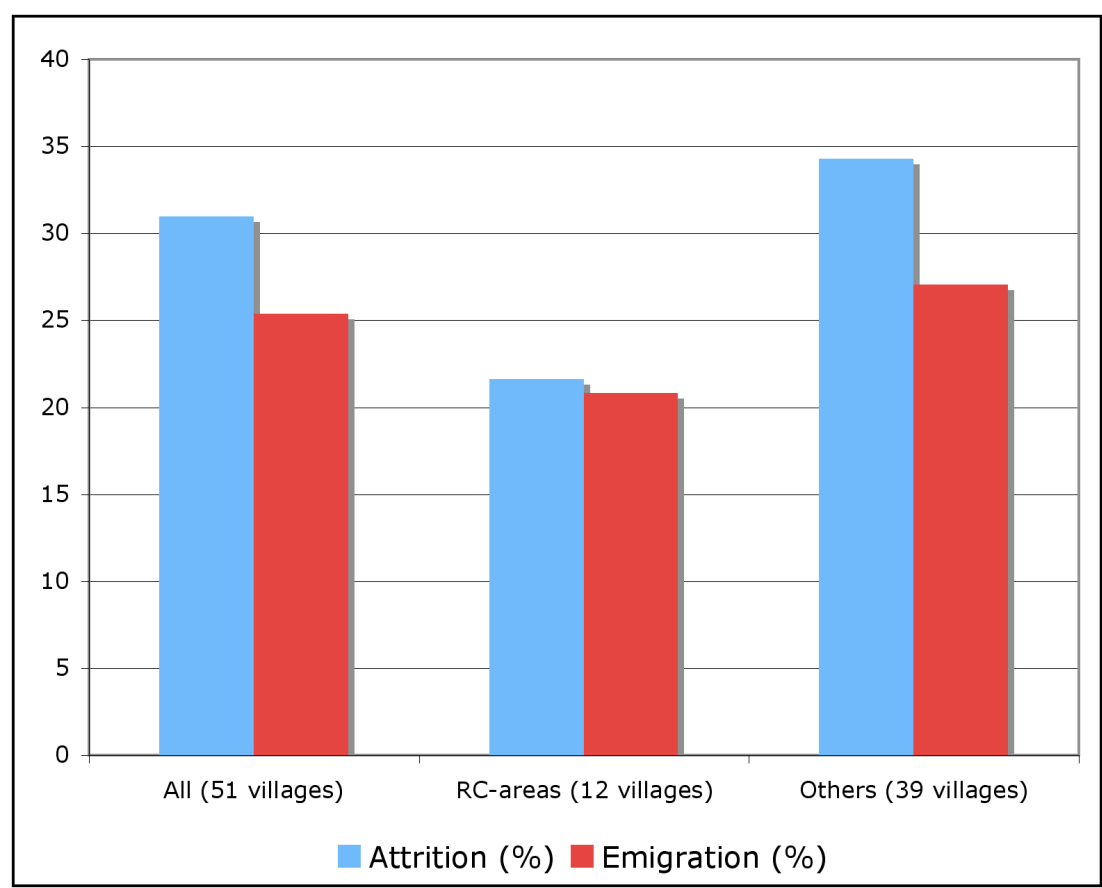




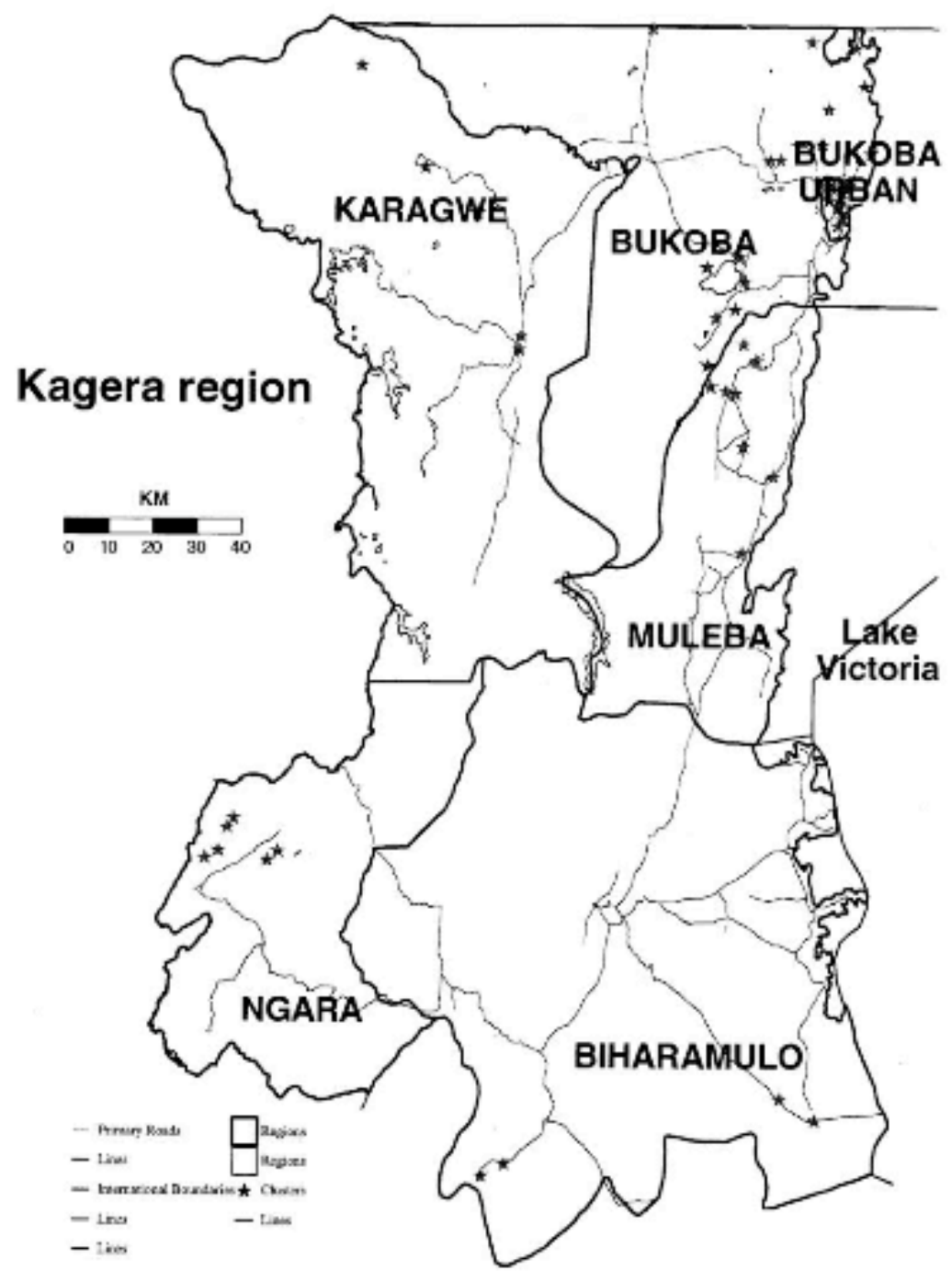

Figure 4: KHDS 2004 
Table 2: Descriptive statistics

\begin{tabular}{|l|c|c|c|c|c|}
\hline Variables & Obs & Mean & Std. Dev. & Min & Max \\
\hline Cons(PAE, 1991) & 2046 & 217646.7 & 144837 & 20007.14 & 1491798 \\
Cons (PAE, 2004) & 2064 & 306802.9 & 243458.3 & 23775.18 & 2758511 \\
\hline Cons(per cap.,1991) & 2040 & 188035.4 & 153851.9 & 14951.97 & 1256506 \\
Cons(per cap.,2004) & 2067 & 248641.5 & 247665.9 & 16969.46 & 4771619 \\
\hline Cons(PAE,t) & 4110 & 262420 & 205393.8 & 20007.14 & 2758511 \\
log(cons(PAE,t)) & 4110 & 12.27243 & .6169704 & 9.903845 & 14.8302 \\
\hline Size(1991) & 2120 & 6.898113 & 3.702479 & 1 & 30 \\
Size(2004) & 2064 & 4.768895 & 2.581935 & 1 & 22 \\
Log(land,1991) & 2126 & 11.66682 & 2.4293 & 0 & 17.92384 \\
Log(land,2004) & 2126 & 9.875798 & 4.652381 & 0 & 17.76653 \\
Prop. Lit. (1991) & 2126 & .5248823 & .2479797 & 0 & 1 \\
Prop. Lit (2004) & 2126 & .5695399 & .2942705 & 0 & 1 \\
\hline Subs.(1991) & 2126 & .5865475 & .4925684 & 0 & 1 \\
Subs.(2004) & 2126 & .7168391 & .4506399 & 0 & 1 \\
Crop sales(1991) & 2126 & .3222013 & .4674296 & 0 & 1 \\
Crop sales(2004) & 2126 & .0456256 & .2087208 & 0 & 1 \\
Agri. L(1991) & 2126 & .2121355 & .4089164 & 0 & 1 \\
Agri. L(2004) & 2126 & .0898401 & .2860198 & 0 & 1 \\
NonAgri.L(1991) & 2126 & .0277516 & .1642991 & 0 & 1 \\
NonAgri.L(2004) & 2126 & .1745061 & .3796334 & 0 & 1 \\
Business(1991) & 2126 & .1853246 & .388652 & 0 & 1 \\
Business(2004) & 2126 & .2196613 & .4141146 & 0 & 1 \\
LVST(1991) & 2126 & .2878645 & .4528742 & 0 & 1 \\
LVST(2004) & 2126 & .1444026 & .3515802 & 0 & 1 \\
\hline Migr(kag) & 2126 & .173095 & .3784184 & 0 & 1 \\
Migr(out) & 2126 & .0733772 & .2608161 & 0 & 1 \\
Prop.migr.(Kag) & 2126 & .1398416 & .2245621 & 0 & 1 \\
Prop.migr.(out) & 2126 & .0585224 & .1480509 & 0 & 1 \\
\hline Prop. Migr.(Kag, corrected) & 2126 & .1031855 & .1940602 & 0 & 1 \\
Prop. Migr.(out, corrected) & 2126 & .0435935 & .1230459 & 0 & 1 \\
\hline Past prop.Migr.(Kag) & 2126 & .0332681 & .0976359 & 0 & .8181818 \\
Past prop.Migr(out) & 2126 & .1262255 & .1920051 & 0 & .9166667 \\
\hline Spillover(out, 2004) & 2126 & 3.786924 & 4.797376 & 0 & 23 \\
Spillover(out, 1991) & 2126 & 14.98542 & 13.73207 & 0 & 53 \\
Spillover(kag, 2004) & 2126 & 11.76999 & 5.782917 & 1 & 32 \\
Spillover(kag, 1991) & 2126 & 2.936971 & 3.144336 & 0 & 13 \\
\hline
\end{tabular}

Activity dummies respectively indicate whether one household generates in a greater proportion than the sample average its income from subsistence agriculture (Subs.), self-employed agricultural activities (Crop Sales), employed agricultural worker (Agri. L), employed nonagricultural worker (Nonagri. L) and self-employed business (Business) or livestock (LVST) activities ; while other variables represent the size of the household (Size), the value of land transformed in real terms and in per adult equivalent (Land), the proportion of literate people in the household (Prop. Lit.). Prop. Migr(Kag) and Prop. Migr(out) respectively indicate the proportion of individuals within the initial household who have migrated outside their original village or its neighborhood in the region of Kagera (Kag) and outside the region of Kagera (out). Migr.(out) and Migr.(kag) respectively indicate whether the household head has migrated outside their original village or its neighborhood in the region of Kagera (Kag) and outside the region of Kagera (out). Spillovers represent the migration spillovers at the village level while HH Prop. Migr. (corrected), the number of household members migrating (excluding the one for which the index is computed). 
Table 3: Household Fixed Effect (excluding split-off households)

\begin{tabular}{|c|c|c|c|c|}
\hline & $\begin{array}{c}(1) \\
\text { HHFE }\end{array}$ & $\begin{array}{c}(2) \\
\text { HHFE }\end{array}$ & $\begin{array}{c}(3) \\
\text { HHFE }\end{array}$ & $\begin{array}{c}(4) \\
\text { HHFE }\end{array}$ \\
\hline & split. excl. & split. excl. & split. excl. & split. excl. \\
\hline $\mathrm{RI}$ & $\begin{array}{c}0.000217 \\
(0.000349)\end{array}$ & $\begin{array}{l}-0.000185 \\
(0.000186)\end{array}$ & $\begin{array}{c}-0.0120^{* * *} \\
(0.00145)\end{array}$ & $\begin{array}{c}-0.0114^{* * *} \\
(0.00172)\end{array}$ \\
\hline $\mathrm{RI}^{2}$ & & & $\begin{array}{c}4.61 \mathrm{e}-05^{* * *} \\
(5.10 \mathrm{e}-06)\end{array}$ & $\begin{array}{c}4.44 \mathrm{e}-05^{* * *} \\
(6.28 \mathrm{e}-06)\end{array}$ \\
\hline Crop Sales & & $\begin{array}{c}0.0151 \\
(0.0520)\end{array}$ & $\begin{array}{l}0.00810 \\
(0.0533)\end{array}$ & $\begin{array}{c}0.0108 \\
(0.0427)\end{array}$ \\
\hline NonAgri.L & & $\begin{array}{c}0.0990 \\
(0.0584)\end{array}$ & $\begin{array}{c}0.0917 \\
(0.0599)\end{array}$ & $\begin{array}{c}0.0893 \\
(0.0788)\end{array}$ \\
\hline Agri. L & & $\begin{array}{c}0.0970 \\
(0.0942)\end{array}$ & $\begin{array}{c}0.0910 \\
(0.0922)\end{array}$ & $\begin{array}{c}0.114 \\
(0.144)\end{array}$ \\
\hline Business & & $\begin{array}{l}0.228^{* *} \\
(0.0741)\end{array}$ & $\begin{array}{l}0.236^{* *} \\
(0.0721)\end{array}$ & $\begin{array}{l}0.233^{* *} \\
(0.0850)\end{array}$ \\
\hline LVST & & $\begin{array}{l}0.00295 \\
(0.0675)\end{array}$ & $\begin{array}{l}0.00486 \\
(0.0656)\end{array}$ & $\begin{array}{l}0.00984 \\
(0.0806)\end{array}$ \\
\hline $\begin{array}{l}\text { Crop Sales } \\
*^{*} \text { RI }\end{array}$ & & $\begin{array}{c}-5.241^{* * *} \\
(0.645)\end{array}$ & $\begin{array}{c}-5.331^{* * *} \\
(0.616)\end{array}$ & $\begin{array}{c}-5.355^{* * *} \\
(0.482)\end{array}$ \\
\hline NonAgri. & & $0.00688^{*}$ & $0.0168^{* * *}$ & $0.0172^{* * *}$ \\
\hline $\mathrm{L}^{*} \mathrm{RI}$ & & $(0.00284)$ & $(0.00202)$ & $(0.00143)$ \\
\hline Agri. & & 0.0125 & $0.0232^{* *}$ & $0.0228^{* *}$ \\
\hline $\mathrm{L} * \mathrm{RI}$ & & $(0.00896)$ & $(0.00765)$ & $(0.00734)$ \\
\hline Business & & $-0.00274^{* *}$ & $-0.00228^{* *}$ & $-0.00235^{* *}$ \\
\hline *RI & & $(0.000687)$ & $(0.000633)$ & $(0.000652)$ \\
\hline LVST & & $0.00195^{* * *}$ & $0.00186^{* * *}$ & $0.00175^{* * *}$ \\
\hline *RI & & $(0.000201)$ & $(0.000207)$ & $(0.000364)$ \\
\hline $\log ($ land $)$ & $\begin{array}{c}0.00477 \\
(0.00744)\end{array}$ & $\begin{array}{c}0.00449 \\
(0.00737)\end{array}$ & $\begin{array}{c}0.00413 \\
(0.00717)\end{array}$ & $\begin{array}{c}0.0115 \\
(0.00577)\end{array}$ \\
\hline Prop.Lit. & $\begin{array}{c}0.187[0.184] \\
(0.121)\end{array}$ & $\begin{array}{c}0.179 \\
(0.125)\end{array}$ & $\begin{array}{c}0.177 \\
(0.123)\end{array}$ & $\begin{array}{c}0.152[0.11] \\
\quad(0.0783)\end{array}$ \\
\hline Size & $\begin{array}{c}-0.0586^{* *} \\
(0.0195)\end{array}$ & $\begin{array}{c}-0.0596^{* *} \\
(0.0194)\end{array}$ & $\begin{array}{c}-0.0593^{* *} \\
(0.0194)\end{array}$ & $\begin{array}{c}-0.0616^{* *} \\
(0.0177)\end{array}$ \\
\hline$\alpha_{t}$ & $\begin{array}{c}0.0594 \\
(0.0467)\end{array}$ & $\begin{array}{c}0.0461 \\
(0.0494)\end{array}$ & $\begin{array}{c}0.0542 \\
(0.0475)\end{array}$ & $\begin{array}{c}0.0341 \\
(0.0477)\end{array}$ \\
\hline $\begin{array}{l}\text { Cluster D } \\
\text { Constant }\end{array}$ & $\begin{array}{c}12.40^{* * * *} \\
(0.179)\end{array}$ & $\begin{array}{c}12.34^{* * *} \\
(0.167)\end{array}$ & $\begin{array}{c}12.35^{* * * *} \\
(0.167) \\
\end{array}$ & $\begin{array}{c}\text { sign. } \\
11.86^{* * *} \\
(0.0677)\end{array}$ \\
\hline $\begin{array}{l}\text { Obs. } \\
R^{2} \\
\text { F-Test }\end{array}$ & $\begin{array}{c}1537 \\
0.121 \\
63.45^{* * *}\end{array}$ & $\begin{array}{c}1537 \\
0.154 \\
49.68^{* * *}\end{array}$ & $\begin{array}{c}1537 \\
0.161 \\
272.16^{* * *}\end{array}$ & $\begin{array}{c}1537 \\
0.260 \\
149.17^{* * *}\end{array}$ \\
\hline
\end{tabular}

Note: ${ }^{* * *} p<0.01,{ }^{* *} p<0.05,{ }^{*} p<0.1 ;$ Robust standard errors in parentheses and clustered at the district level (allowing for correlation of errors within districts). Between brackets, are included the p-value of coefficients closed to significance. 
Table 4: Household Fixed Effect (excl. migrants and incl. split-offs)

\begin{tabular}{|c|c|c|c|c|c|c|c|c|}
\hline & $\begin{array}{c}(1) \\
\text { HHFE }\end{array}$ & $\begin{array}{c}(2) \\
\text { HHFE }\end{array}$ & $\begin{array}{c}(3) \\
\text { HHFE }\end{array}$ & $\begin{array}{c}(4) \\
\text { HHFE }\end{array}$ & $\begin{array}{c}5) \\
\text { HHFE } \\
(2 \mathrm{SLS})\end{array}$ & $\begin{array}{c}(6) \\
\text { HHFE } \\
(2 \mathrm{SLS})\end{array}$ & $\begin{array}{c}(7) \\
\text { HHFE } \\
(2 \mathrm{SLS})\end{array}$ & $\begin{array}{c}(8) \\
\text { HHFE } \\
(2 S L S)\end{array}$ \\
\hline & split. incl & split. incl. & split. incl. & split. incl. & split. incl. & split. incl. & split. incl. & split. incl. \\
\hline RI & $\begin{array}{c}0.0004 \\
(0.000291) \\
{[0.177]}\end{array}$ & $\begin{array}{c}0.0005^{*} \\
(0.000246)\end{array}$ & $\begin{array}{c}-0.0017 \\
(0.00175)\end{array}$ & $\begin{array}{c}-0.0024 \\
(0.00259)\end{array}$ & $\begin{array}{l}0.0005^{* * *} \\
(0.000184)\end{array}$ & $\begin{array}{l}0.0005^{* * *} \\
(0.000151)\end{array}$ & $\begin{array}{c}-0.0016 \\
(0.00121) \\
{[0.195]}\end{array}$ & $\begin{array}{c}-0.0022 \\
(0.00174)\end{array}$ \\
\hline $\mathrm{RI}^{2}$ & & & $\begin{array}{c}8.92 \mathrm{e}-06 \\
(5.96 \mathrm{e}-06) \\
{[0.195]}\end{array}$ & $\begin{array}{c}1.14 \mathrm{e}-05 \\
(8.82 \mathrm{e}-06)\end{array}$ & & & $\begin{array}{c}8.25 \mathrm{e}-06^{* *} \\
(4.18 \mathrm{e}-06)\end{array}$ & $\begin{array}{c}1.04 \mathrm{e}-05^{*} \\
(6.10 \mathrm{e}-06)\end{array}$ \\
\hline Crop Sales & & $\begin{array}{l}-0.0352 \\
(0.0533)\end{array}$ & $\begin{array}{l}-0.0362 \\
(0.0527)\end{array}$ & $\begin{array}{l}-0.0329 \\
(0.0579)\end{array}$ & & $\begin{array}{l}-0.0322 \\
(0.0366)\end{array}$ & $\begin{array}{l}-0.0326 \\
(0.0364)\end{array}$ & $\begin{array}{l}-0.0254 \\
(0.0421)\end{array}$ \\
\hline NonAgri.L & & $\begin{array}{l}0.193^{* *} \\
(0.0518)\end{array}$ & $\begin{array}{l}0.192^{* *} \\
(0.0516)\end{array}$ & $\begin{array}{c}0.155^{*} \\
(0.0638)\end{array}$ & & $\begin{array}{c}0.199^{* * *} \\
(0.0315)\end{array}$ & $\begin{array}{c}0.198^{* * *} \\
(0.0317)\end{array}$ & $\begin{array}{c}0.168^{* * *} \\
(0.0352)\end{array}$ \\
\hline Agri. L & & $\begin{array}{c}0.138 \\
(0.0822)\end{array}$ & $\begin{array}{c}0.137 \\
(0.0816)\end{array}$ & $\begin{array}{c}0.130 \\
(0.0849)\end{array}$ & & $\begin{array}{c}0.140^{* * *} \\
(0.0455)\end{array}$ & $\begin{array}{c}0.140^{* * *} \\
(0.0454)\end{array}$ & $\begin{array}{c}0.135^{* * *} \\
(0.0472)\end{array}$ \\
\hline Business & & $\begin{array}{l}0.249^{* *} \\
(0.0797)\end{array}$ & $\begin{array}{l}0.250^{* *} \\
(0.0793)\end{array}$ & $\begin{array}{l}0.239^{* *} \\
(0.0703)\end{array}$ & & $\begin{array}{c}0.265^{* * *} \\
(0.0769)\end{array}$ & $\begin{array}{c}0.266^{* * *} \\
(0.0761)\end{array}$ & $\begin{array}{c}0.262^{* * *} \\
(0.0703)\end{array}$ \\
\hline LVST & & $\begin{array}{c}0.0149 \\
(0.0878)\end{array}$ & $\begin{array}{c}0.0148 \\
(0.0877)\end{array}$ & $\begin{array}{c}0.0158 \\
(0.0880)\end{array}$ & & $\begin{array}{c}0.0156 \\
(0.0552)\end{array}$ & $\begin{array}{c}0.0158 \\
(0.0550)\end{array}$ & $\begin{array}{c}0.0177 \\
(0.0529)\end{array}$ \\
\hline $\begin{array}{l}\text { Crop } \\
\text { Sales*RI }\end{array}$ & & $\begin{array}{l}0.0014^{*} \\
(0.0006)\end{array}$ & $\begin{array}{l}0.0015^{*} \\
(0.0006)\end{array}$ & $\begin{array}{c}0.0016^{* *} \\
(0.0006)\end{array}$ & & $\begin{array}{c}0.0014^{* *} \\
(0.0007)\end{array}$ & $\begin{array}{c}0.0015^{* *} \\
(0.0007)\end{array}$ & $\begin{array}{c}0.0014^{* *} \\
(0.0007)\end{array}$ \\
\hline NonAgri. & & $0.0014^{* * *}$ & $0.0014^{* * *}$ & $0.0016^{* * *}$ & & $0.0014^{* * *}$ & $0.0015 * * *$ & $0.0016^{* * *}$ \\
\hline $\mathrm{L}^{*} \mathrm{RI}$ & & $(0.0002)$ & $(0.0002)$ & $(0.0003)$ & & $(0.0002)$ & $(0.0001)$ & $(0.0001)$ \\
\hline Agri. & & $-0.0018^{* *}$ & $-0.0018^{* *}$ & $-0.0019 * * *$ & & $-0.0018^{* * *}$ & $-0.0018^{* * *}$ & $-0.0019 * * *$ \\
\hline $\mathrm{L} * \mathrm{RI}$ & & $(0.0005)$ & $(0.0005)$ & $(0.0004)$ & & $(0.0003)$ & $(0.0003)$ & $(0.0003)$ \\
\hline Business & & $-0.0025^{* * *}$ & $-0.0025^{* * *}$ & $-0.0023^{* * *}$ & & $-0.0026^{* * *}$ & $-0.0024^{* * *}$ & $-0.0024^{* * *}$ \\
\hline$* \mathrm{RI}$ & & $(0.0003)$ & $(0.0004)$ & $(0.0004)$ & & $(0.0003)$ & $(0.0003)$ & $(0.0003)$ \\
\hline LVST & & $0.0008^{* *}$ & $0.0008^{* *}$ & $0.0008^{*}$ & & $0.0009^{* * *}$ & $0.0009^{* * *}$ & $0.0009 * *$ \\
\hline$*_{\mathrm{RI}}$ & & $(0.0003)$ & $(0.0003)$ & $(0.0004)$ & & $(0.0003)$ & $(0.0003)$ & $(0.0004)$ \\
\hline $\log ($ land $)$ & $\begin{array}{c}-0.005 \\
(0.0073)\end{array}$ & $\begin{array}{l}-0.0019 \\
(0.0078)\end{array}$ & $\begin{array}{c}-0.002 \\
(0.0078)\end{array}$ & $\begin{array}{c}0.0013 \\
(0.0073)\end{array}$ & $\begin{array}{l}-0.0036 \\
(0.0052)\end{array}$ & $\begin{array}{c}-0.001 \\
(0.0057)\end{array}$ & $\begin{array}{l}-0.0012 \\
(0.0058)\end{array}$ & $\begin{array}{c}0.0012 \\
(0.0043)\end{array}$ \\
\hline Prop.Lit. & $\begin{array}{c}0.183 \\
(0.109) \\
{[0.152]}\end{array}$ & $\begin{array}{c}0.171 \\
(0.115) \\
{[0.197]}\end{array}$ & $\begin{array}{c}0.170 \\
(0.115)\end{array}$ & $\begin{array}{c}0.153 \\
(0.0905) \\
{[0.151]}\end{array}$ & $\begin{array}{c}0.180 * * * \\
(0.0693)\end{array}$ & $\begin{array}{l}0.166^{* *} \\
(0.0713)\end{array}$ & $\begin{array}{l}0.165^{* *} \\
(0.0716)\end{array}$ & $\begin{array}{c}0.148^{* * *} \\
(0.0561)\end{array}$ \\
\hline Size & $\begin{array}{l}-0.0386 \\
(0.021) \\
{[0.120]}\end{array}$ & $\begin{array}{c}-0.0409^{*} \\
(0.019)\end{array}$ & $\begin{array}{c}-0.0408^{*} \\
(0.019)\end{array}$ & $\begin{array}{c}-0.0419 * \\
(0.018)\end{array}$ & $\begin{array}{c}-0.0379^{* * *} \\
(0.012)\end{array}$ & $\begin{array}{c}-0.0405^{* * *} \\
(0.0114)\end{array}$ & $\begin{array}{c}-0.0405^{* * *} \\
(0.0114)\end{array}$ & $\begin{array}{c}-0.0417^{* * *} \\
(0.0104)\end{array}$ \\
\hline Split-off & $\begin{array}{c}0.121 \\
(0.0826)\end{array}$ & $\begin{array}{c}0.112[0.189] \\
(0.0738)\end{array}$ & $\begin{array}{c}0.112[0.189] \\
(0.0733)\end{array}$ & $\begin{array}{c}0.105 \\
(0.0786)\end{array}$ & $\begin{array}{c}0.135^{* * *} \\
(0.0485)\end{array}$ & $\begin{array}{c}0.115^{* * *} \\
(0.0415)\end{array}$ & $\begin{array}{c}0.114^{* * *} \\
(0.0406)\end{array}$ & $\begin{array}{c}0.107^{* * *} \\
(0.0392)\end{array}$ \\
\hline Migr.(Kag) & $\begin{array}{c}0.151 \\
(0.0886)\end{array}$ & $\begin{array}{l}0.232^{*} \\
(0.105)\end{array}$ & $\begin{array}{l}0.231^{*} \\
(0.105)\end{array}$ & $\begin{array}{c}0.0752 \\
(0.0913)\end{array}$ & $\begin{array}{c}0.272 \\
(0.271)\end{array}$ & $\begin{array}{c}0.336 \\
(0.294)\end{array}$ & $\begin{array}{c}0.334 \\
(0.295)\end{array}$ & $\begin{array}{c}0.313 \\
(0.447)\end{array}$ \\
\hline $\begin{array}{l}\text { Prop. } \\
\text { Migr.(out) }\end{array}$ & $\begin{array}{c}0.330 \\
(0.186) \\
{[0.136]} \\
\end{array}$ & $\begin{array}{l}0.357 \\
(0.181) \\
{[0.106]} \\
\end{array}$ & $\begin{array}{c}0.358 \\
(0.180) \\
{[0.103]} \\
\end{array}$ & $\begin{array}{l}0.358^{*} \\
(0.173)\end{array}$ & $\begin{array}{c}0.187 \\
(0.392)\end{array}$ & $\begin{array}{c}0.383 \\
(0.388)\end{array}$ & $\begin{array}{c}0.404 \\
(0.387)\end{array}$ & $\begin{array}{c}0.483 \\
(0.428)\end{array}$ \\
\hline $\begin{array}{l}\alpha_{t} \\
\text { Cluster D }\end{array}$ & $\begin{array}{c}0.0712 \\
(0.0479)\end{array}$ & $\begin{array}{c}0.0301 \\
(0.0582)\end{array}$ & $\begin{array}{c}0.0331 \\
(0.0566)\end{array}$ & $\begin{array}{c}0.0285 \\
(0.0696) \\
\text { sign. }\end{array}$ & $\begin{array}{c}0.0298 \\
(0.0681)\end{array}$ & $\begin{array}{c}0.0117 \\
(0.0740)\end{array}$ & $\begin{array}{c}0.0172 \\
(0.0756)\end{array}$ & $\begin{array}{c}0.0286 \\
(0.0446) \\
\text { sign. }\end{array}$ \\
\hline Obs. & 3803 & 3803 & 3803 & 3803 & 3674 & 3674 & 3674 & 3674 \\
\hline$R^{2}$ & 0.185 & 0.227 & 0.227 & 0.287 & 0.181 & 0.224 & 0.224 & 0.279 \\
\hline F-Test & $201.78^{* * *}$ & $4.00^{* * *}$ & $3.91^{* * *}$ & $18.91^{* * *}$ & $53.65^{* * *}$ & $7.32^{* *}$ & $7.22^{* *}$ & $4.80^{*}$ \\
\hline $\begin{array}{l}\text { Anderson } \\
\text { Stock-Yogo } \\
\text { Hansen }^{a} \\
\text { (p-value) }\end{array}$ & & & 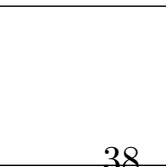 & & $\begin{array}{c}147.68^{* * *} \\
51.09 \\
0.167 \\
(0.68)\end{array}$ & $\begin{array}{c}144.39^{* * *} \\
49.55 \\
0.163 \\
(0.68)\end{array}$ & $\begin{array}{c}144.58^{* * *} \\
49.6 \\
9.298 \\
(0.69)\end{array}$ & $\begin{array}{c}91.13^{* * *} \\
29.86\end{array}$ \\
\hline
\end{tabular}

Note: ${ }^{* * *} p<0.01,{ }^{* *} p<0.05,{ }^{*} p<0.1$; Between brackets, are included the p-value of coefficients closed to significance. Robust standard errors in parentheses and clustered at the district level. a The overidentification test was obtained by partialling out the household-specific variables. We first check that due to the Frisch-Wargh-Lovell theorem, the coefficients of the remaining variables are unaltered. We then correct the covariance matrix to make the overidentification test feasible. 
Table 5: Household Fixed Effect (excl. migrants): First stage regression

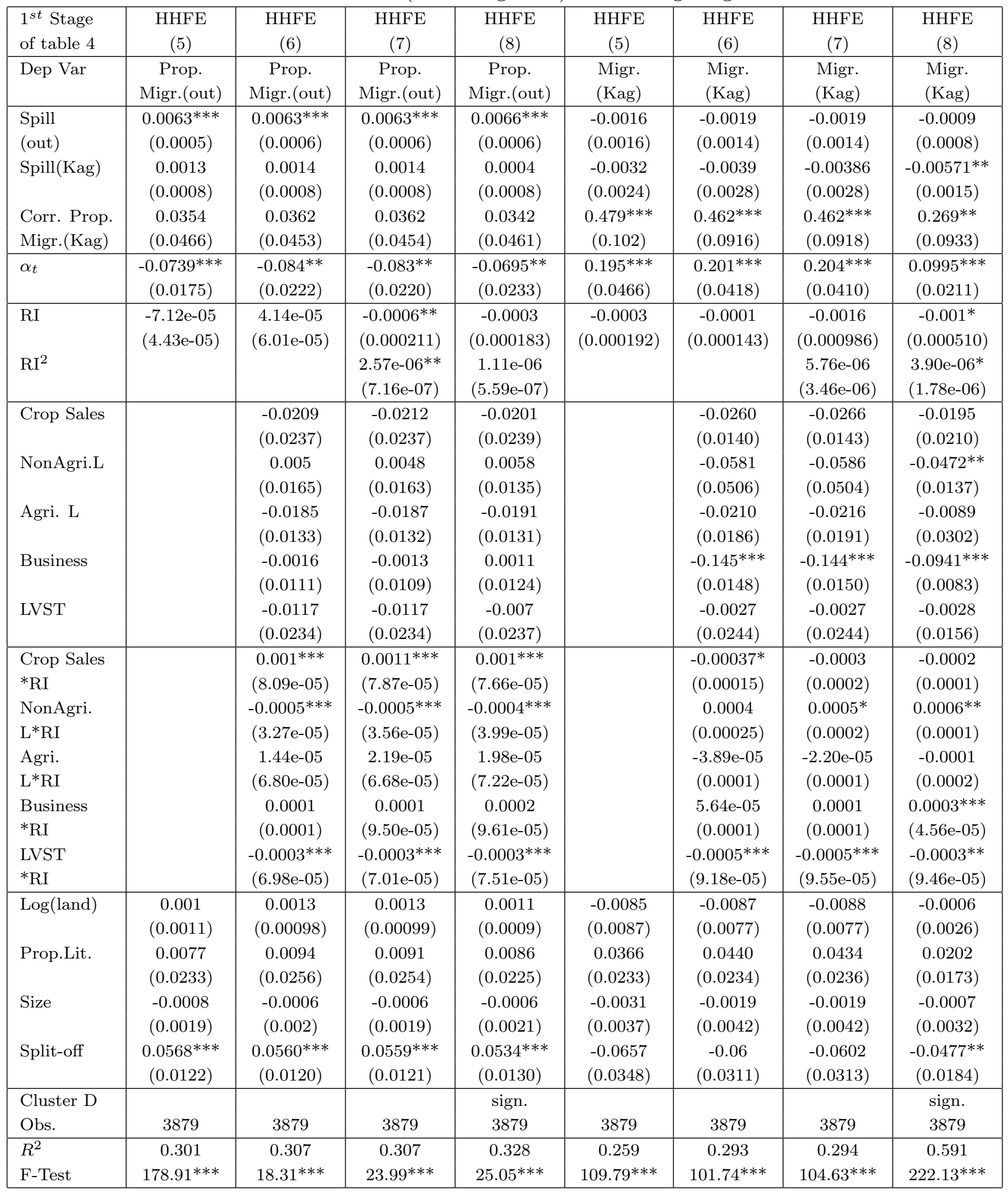

*** $p<0.01,{ }^{* *} p<0.05,{ }^{*} p<0.1$; Robust standard errors in parentheses and clustered at the district level. The variable "Corr. Prop. Migr(Kag)" is the proportion of the initial household which has migrated within the region of Kagera, corrected to keep it exogenous. (see table 2) 
Table 6: Altruism Test based on Altonji et al (1992) and Witoelar (2005)

\begin{tabular}{|c|c|c|c|c|c|c|c|c|}
\hline & $\begin{array}{c}(1) \\
\text { IHFE } \\
(2 \mathrm{SLS})\end{array}$ & $\begin{array}{c}(2) \\
\text { IHFE } \\
(2 \mathrm{SLS})\end{array}$ & $\begin{array}{c}(3) \\
\text { IHFE } \\
(2 \mathrm{SLS})\end{array}$ & $\begin{array}{c}(4) \\
\text { IHFE } \\
(2 \mathrm{SLS})\end{array}$ & $\begin{array}{c}(5) \\
\text { IHFE } \\
(2 \mathrm{SLS})\end{array}$ & $\begin{array}{c}(6) \\
\text { IHFE } \\
(2 \mathrm{SLS})\end{array}$ & $\begin{array}{c}(7) \\
\text { IHFE } \\
(2 \mathrm{SLS})\end{array}$ & $\begin{array}{c}(8) \\
\text { IHFE } \\
(2 \mathrm{SLS})\end{array}$ \\
\hline IV & Witoelar & Witoelar & $\begin{array}{c}\text { Dist } \\
\text { (Road) }\end{array}$ & $\begin{array}{c}\text { Dist } \\
\text { (Road) }\end{array}$ & $\begin{array}{c}\text { Dist } \\
\text { (Road) }\end{array}$ & $\begin{array}{c}\text { Dist } \\
\text { (Road) }\end{array}$ & $\begin{array}{c}\text { Dist } \\
\text { (Road) }\end{array}$ & $\begin{array}{c}\text { Dist } \\
\text { (Road) }\end{array}$ \\
\hline $\begin{array}{l}\text { Split-off } \\
\text { Migr.(Out) }\end{array}$ & $\begin{array}{l}\text { incl. } \\
\text { excl. }\end{array}$ & $\begin{array}{l}\text { incl. } \\
\text { excl. }\end{array}$ & $\begin{array}{l}\text { incl. } \\
\text { excl. }\end{array}$ & $\begin{array}{l}\text { incl. } \\
\text { excl. }\end{array}$ & $\begin{array}{l}\text { incl. } \\
\text { excl. }\end{array}$ & $\begin{array}{l}\text { incl. } \\
\text { incl. }\end{array}$ & $\begin{array}{l}\text { incl. } \\
\text { incl. }\end{array}$ & $\begin{array}{l}\text { incl. } \\
\text { incl. }\end{array}$ \\
\hline Dep Var & $\log ($ cons $)$ & $\log ($ cons $)$ & $\log ($ cons $)$ & $\log ($ cons $)$ & $\log ($ cons $)$ & log(cons) & $\log ($ cons $)$ & $\log ($ cons $)$ \\
\hline $\log ($ netinc $)$ & $\begin{array}{c}0.125 \\
(0.0726) \\
{[0.146]}\end{array}$ & $\begin{array}{c}0.142 \\
(0.0828) \\
{[0.146]}\end{array}$ & $\begin{array}{c}0.517^{* * *} \\
(0.0116)\end{array}$ & $\begin{array}{c}0.585^{* * *} \\
(0.0145)\end{array}$ & $\begin{array}{c}0.610^{* * *} \\
(0.0258)\end{array}$ & $\begin{array}{c}0.536^{* * *} \\
(0.0174)\end{array}$ & $\begin{array}{c}0.583^{* * *} \\
(0.0142)\end{array}$ & $\begin{array}{c}0.603^{* * *} \\
(0.0272)\end{array}$ \\
\hline$\alpha_{t}$ & $\begin{array}{l}0.168^{* * *} \\
(0.00926)\end{array}$ & $\begin{array}{c}0.0968^{* * *} \\
(0.0159)\end{array}$ & $\begin{array}{c}0.251^{* * *} \\
(0.0495)\end{array}$ & $\begin{array}{l}0.153^{* *} \\
(0.0414)\end{array}$ & $\begin{array}{l}0.185^{* *} \\
(0.0519)\end{array}$ & $\begin{array}{c}0.316^{* * *} \\
(0.0756)\end{array}$ & $\begin{array}{l}0.166^{* *} \\
(0.0633)\end{array}$ & $\begin{array}{c}0.192^{*} \\
(0.0797)\end{array}$ \\
\hline RI & $\begin{array}{l}0.0003^{*} \\
(0.0001)\end{array}$ & $\begin{array}{l}0.0004^{*} \\
(0.0001)\end{array}$ & $\begin{array}{c}-1.34 \mathrm{e}-05 \\
(0.0002)\end{array}$ & $\begin{array}{c}0.0002 \\
(0.0002)\end{array}$ & $\begin{array}{l}0.0004^{*} \\
(0.0002)\end{array}$ & $\begin{array}{c}-1.46 \mathrm{e}-05 \\
(0.0003)\end{array}$ & $\begin{array}{c}0.0004 \\
(0.0002)\end{array}$ & $\begin{array}{c}0.0005^{* *} \\
(0.0002)\end{array}$ \\
\hline Size & $\begin{array}{c}-0.0521^{* *} \\
(0.0152)\end{array}$ & $\begin{array}{c}-0.0493^{* *} \\
(0.0143)\end{array}$ & $\begin{array}{c}-0.0534^{* * *} \\
(0.0119)\end{array}$ & $\begin{array}{c}-0.0373^{* *} \\
(0.00953)\end{array}$ & $\begin{array}{l}-0.0354^{* *} \\
(0.00982)\end{array}$ & $\begin{array}{c}-0.0494^{* *} \\
(0.0144)\end{array}$ & $\begin{array}{c}-0.0297^{* *} \\
(0.0113)\end{array}$ & $\begin{array}{c}-0.0281^{*} \\
(0.0124)\end{array}$ \\
\hline Prop.Lit. & $\begin{array}{c}0.223^{* * *} \\
(0.0552)\end{array}$ & $\begin{array}{l}0.219 * * \\
(0.0550)\end{array}$ & $\begin{array}{c}0.193^{* * *} \\
(0.0455)\end{array}$ & $\begin{array}{l}0.175^{* *} \\
(0.0524)\end{array}$ & $\begin{array}{l}0.177^{* *} \\
(0.0539)\end{array}$ & $\begin{array}{c}0.316^{* * *} \\
(0.0445)\end{array}$ & $\begin{array}{l}0.207^{* *} \\
(0.0558)\end{array}$ & $\begin{array}{l}0.208^{* *} \\
(0.0567)\end{array}$ \\
\hline dumnewhh & & $\begin{array}{c}0.0850 \\
(0.0492)\end{array}$ & & $\begin{array}{c}0.0558 \\
(0.0515)\end{array}$ & $\begin{array}{c}0.0510 \\
(0.0514)\end{array}$ & & $\begin{array}{c}0.0423 \\
(0.0474)\end{array}$ & $\begin{array}{c}0.0379 \\
(0.0471)\end{array}$ \\
\hline $\begin{array}{l}\text { Prop. Migr. } \\
\text { (out) }{ }^{b} \\
\text { Migr.(Kag) }\end{array}$ & & $\begin{array}{c}0.274 \\
(0.137) \\
0.218^{*} \\
(0.0915)\end{array}$ & & $\begin{array}{c}0.140 \\
(0.120) \\
0.352^{* * *} \\
(0.0459)\end{array}$ & $\begin{array}{c}0.146 \\
(0.120) \\
0.363^{* * *} \\
(0.0424)\end{array}$ & & $\begin{array}{c}0.590^{* * *} \\
(0.124) \\
0.346^{* * *} \\
(0.0432)\end{array}$ & $\begin{array}{c}0.585^{* * *} \\
(0.126) \\
0.354^{* * *} \\
(0.0400)\end{array}$ \\
\hline $\begin{array}{l}\log (\text { land }) \\
\log (\text { Bus }) \\
\text { Log(eqip) }\end{array}$ & & & & $\begin{array}{c}-0.0487^{* * *} \\
(0.00820)\end{array}$ & $\begin{array}{c}-0.0477 * * * \\
(0.00811) \\
0.000865 \\
(0.00358) \\
-0.00834 \\
(0.00481)\end{array}$ & & $\begin{array}{c}-0.0499 * * * \\
(0.00600)\end{array}$ & $\begin{array}{c}-0.0488 * * * \\
(0.00585) \\
0.00125 \\
(0.00530) \\
-0.00670 \\
(0.00485)\end{array}$ \\
\hline Constant & $\begin{array}{c}10.37^{* * * *} \\
(0.847)\end{array}$ & $\begin{array}{c}10.11^{* * * *} \\
(0.948)\end{array}$ & $\begin{array}{c}5.926^{* * *} \\
(0.178)\end{array}$ & $\begin{array}{c}5.655^{* * *} \\
(0.148)\end{array}$ & $\begin{array}{c}5.368^{* * *} \\
(0.294)\end{array}$ & $\begin{array}{c}5.621^{* * *} \\
(0.262)\end{array}$ & $\begin{array}{c}5.668^{* * *} \\
(0.202)\end{array}$ & $\begin{array}{c}5.439^{* * *} \\
(0.352)\end{array}$ \\
\hline IHFE & sign. & sign. & sign. & sign. & sign. & sign. & sign. & sign. \\
\hline $\begin{array}{l}\text { Obs. } \\
\text { R-squared }\end{array}$ & $\begin{array}{c}3781 \\
0.609 \\
\end{array}$ & $\begin{array}{l}3781 \\
0.621 \\
\end{array}$ & $\begin{array}{l}3781 \\
0.333 \\
\end{array}$ & $\begin{array}{c}3781 \\
0.290 \\
\end{array}$ & $\begin{array}{c}3781 \\
0.248 \\
\end{array}$ & $\begin{array}{l}4082 \\
0.247 \\
\end{array}$ & $\begin{array}{c}4082 \\
0.275 \\
\end{array}$ & $\begin{array}{l}4082 \\
0.241 \\
\end{array}$ \\
\hline \multicolumn{9}{|l|}{ First Stage } \\
\hline Dep Var & $\log ($ netinc $)$ & $\log ($ netinc $)$ & log(netinc) & $\log ($ netinc $)$ & $\log ($ netinc $)$ & $\log ($ netinc) & $\log ($ netinc) & $\log ($ netinc $)$ \\
\hline $\begin{array}{l}\text { Log(land) } \\
\text { Log(Bus) } \\
\text { Log(eqip) }\end{array}$ & $\begin{array}{c}0.0629 * * * \\
(0.009)^{i v} \\
0.0393^{* * *} \\
(0.004)^{i v} \\
0.0294^{* *} \\
(0.008)^{i v}\end{array}$ & $\begin{array}{c}0.0584^{* * *} \\
(0.009)^{i v} \\
0.0395^{* * *} \\
(0.004)^{i v} \\
0.0291^{* *} \\
(0.008)^{i v}\end{array}$ & & $\begin{array}{c}0.0680 * * * \\
(0.00811)\end{array}$ & $\begin{array}{c}0.0584^{* * *} \\
(0.00860) \\
0.0395 * * * \\
(0.00402) \\
0.0291^{* *} \\
(0.00776)\end{array}$ & & $\begin{array}{c}0.0617^{* * *} \\
(0.00629)\end{array}$ & $\begin{array}{c}0.0521^{* * *} \\
(0.00603) \\
0.0370^{* * *} \\
(0.00677) \\
0.0265^{*} \\
(0.0104)\end{array}$ \\
\hline $\begin{array}{l}\text { Log(road) } \\
\text { (Uganda) } \\
\text { Log(road) } \\
\text { (Rwanda) }\end{array}$ & & & $\begin{array}{c}-0.266^{* * *} \\
(0.032)^{i v} \\
-0.627^{* * *} \\
(0.062)^{i v}\end{array}$ & $\begin{array}{c}-0.135^{* * *} \\
(0.026)^{i v} \\
-0.444^{* * *} \\
(0.051)^{i v}\end{array}$ & $\begin{array}{c}-0.619^{* * *} \\
(0.037)^{i v} \\
-0.794^{* * *} \\
(0.052)^{i v}\end{array}$ & $\begin{array}{c}-0.679 * * * \\
(0.023)^{i v} \\
-0.969 * * * \\
(0.05)^{i v}\end{array}$ & $\begin{array}{c}-0.651^{* * *} \\
(0.019)^{i v} \\
-0.975^{* * *} \\
(0.046)^{i v}\end{array}$ & $\begin{array}{c}-0.663^{* * *} \\
(0.015)^{i v} \\
-0.834^{* * *} \\
(0.043)^{i v}\end{array}$ \\
\hline $\begin{array}{l}\text { Obs. } \\
\text { R-squared }\end{array}$ & $\begin{array}{c}3857 \\
0.379\end{array}$ & $\begin{array}{c}3857 \\
0.388\end{array}$ & $\begin{array}{c}3857 \\
0.328\end{array}$ & $\begin{array}{c}3857 \\
0.368\end{array}$ & $\begin{array}{c}3857 \\
0.388\end{array}$ & $\begin{array}{l}4162 \\
0.316\end{array}$ & $\begin{array}{l}4162 \\
0.359\end{array}$ & $\begin{array}{l}4162 \\
0.376\end{array}$ \\
\hline
\end{tabular}

Note: ${ }^{* * *} p<0.01,{ }^{* *} p<0.05,{ }^{*} p<0.1 ;$ Robust standard errors in parentheses and clustered at the district level. Columns (1) and (2) use the instruments proposed by Witoelar (2005), i.e. the value of land, farm productive equipments and non-farm productive assets. Regressions (3) to (8) use the 40 ance to the main economic partners as $I V$, the distance by road to Uganda and Rwanda. To make this distinction clear in the first-stage estimation, iv indicates instrumental variables that are excluded from the second-stage regression presented in the above part of the table. Regressions (6) to (8) differ from (1) to (5) as the sample used includes those migrating outside the region of Kagera. Therefore, $b$ indicates that the variable "Prop. Migr.(out)" is replaced by the direct measure of the decision to move outside the 
Table 7: Household Fixed Effect (incl. migrants and split-offs)

\begin{tabular}{|c|c|c|c|c|c|c|c|c|}
\hline & $\begin{array}{c}(1) \\
\text { HHFE }\end{array}$ & $\begin{array}{c}(2) \\
\text { HHFE }\end{array}$ & $\begin{array}{c}(3) \\
\text { HHFE }\end{array}$ & $\begin{array}{c}(4) \\
\text { HHFE }\end{array}$ & $\begin{array}{c}(5) \\
\text { HHFE } \\
(2 \mathrm{SLS}) \\
\end{array}$ & $\begin{array}{c}(6) \\
\text { HHFE } \\
(2 \mathrm{SLS})\end{array}$ & $\begin{array}{c}(7) \\
\text { HHFE } \\
(2 \mathrm{SLS}) \\
\end{array}$ & $\begin{array}{c}(8) \\
\text { HHFE } \\
(2 \mathrm{SLS})\end{array}$ \\
\hline & split. incl. & split. incl. & split. incl. & split. incl. & split. incl. & split. incl. & split. incl. & split. incl. \\
\hline $\begin{array}{l}\mathrm{RI} \\
\mathrm{RI}^{2}\end{array}$ & $\begin{array}{l}0.0006^{*} \\
(0.0003)\end{array}$ & $\begin{array}{l}0.0008^{* *} \\
(0.00025)\end{array}$ & $\begin{array}{c}-0.0008 \\
(0.0017) \\
6.30 \mathrm{e}-06 \\
(5.75 \mathrm{e}-06)\end{array}$ & $\begin{array}{c}-0.002 \\
(0.0025) \\
1.03 \mathrm{e}-05 \\
(8.43 \mathrm{e}-06)\end{array}$ & $\begin{array}{c}0.0007^{* * *} \\
(0.0001)\end{array}$ & $\begin{array}{c}0.0009^{* * *} \\
(0.0001)\end{array}$ & $\begin{array}{c}-0.0005 \\
(0.0008) \\
5.47 \mathrm{e}-06^{*} \\
(2.93 \mathrm{e}-06)\end{array}$ & $\begin{array}{c}-0.0016 \\
(0.0018) \\
8.45 \mathrm{e}-06 \\
(6.52 \mathrm{e}-06) \\
{[0.195]}\end{array}$ \\
\hline Crop Sales & & $\begin{array}{l}-0.0535 \\
(0.0521)\end{array}$ & $\begin{array}{l}-0.0542 \\
(0.0517)\end{array}$ & $\begin{array}{l}-0.0463 \\
(0.0625)\end{array}$ & & $\begin{array}{l}-0.0512 \\
(0.0342)\end{array}$ & $\begin{array}{l}-0.0519 \\
(0.0342)\end{array}$ & $\begin{array}{l}-0.0413 \\
(0.0424)\end{array}$ \\
\hline NonAgri.L & & $\begin{array}{l}0.211^{* *} \\
(0.0565)\end{array}$ & $\begin{array}{l}0.210^{* *} \\
(0.0565)\end{array}$ & $\begin{array}{c}0.189^{* *} \\
(0.0606)\end{array}$ & & $\begin{array}{c}0.223^{* * *} \\
(0.0703)\end{array}$ & $\begin{array}{c}0.223^{* * *} \\
(0.0703)\end{array}$ & $\begin{array}{c}0.203^{* * *} \\
(0.0328)\end{array}$ \\
\hline Agri. L & & $\begin{array}{c}0.125 \\
(0.0919)\end{array}$ & $\begin{array}{c}0.124 \\
(0.0915)\end{array}$ & $\begin{array}{c}0.124 \\
(0.0904)\end{array}$ & & $\begin{array}{c}0.125 \\
(0.0881)\end{array}$ & $\begin{array}{c}0.125 \\
(0.0884)\end{array}$ & $\begin{array}{l}0.128^{* *} \\
(0.0552)\end{array}$ \\
\hline Business & & $\begin{array}{c}0.237^{* *} \\
(0.0878)\end{array}$ & $\begin{array}{c}0.237^{* *} \\
(0.0876)\end{array}$ & $\begin{array}{c}0.221^{* *} \\
(0.0714)\end{array}$ & & $\begin{array}{c}0.256^{* * *} \\
(0.0742)\end{array}$ & $\begin{array}{c}0.256^{* * *} \\
(0.0741)\end{array}$ & $\begin{array}{c}0.248^{* * *} \\
(0.0723)\end{array}$ \\
\hline LVST & & $\begin{array}{c}0.0149 \\
(0.0808)\end{array}$ & $\begin{array}{c}0.0147 \\
(0.0809)\end{array}$ & $\begin{array}{c}0.008 \\
(0.0747)\end{array}$ & & $\begin{array}{c}0.0144 \\
(0.0521)\end{array}$ & $\begin{array}{c}0.0142 \\
(0.0522)\end{array}$ & $\begin{array}{c}0.0079 \\
(0.0444)\end{array}$ \\
\hline $\begin{array}{l}\text { Crop Sales } \\
{ }^{*} \text { RI }\end{array}$ & & $\begin{array}{c}0.0017^{* *} \\
(0.0005)\end{array}$ & $\begin{array}{c}0.0018^{* *} \\
(0.0005)\end{array}$ & $\begin{array}{c}0.0019^{* * *} \\
(0.0005)\end{array}$ & & $\begin{array}{c}0.0017^{* * *} \\
(0.0004)\end{array}$ & $\begin{array}{c}0.0018^{* * *} \\
(0.0004)\end{array}$ & $\begin{array}{c}0.0019^{* * *} \\
(0.0003)\end{array}$ \\
\hline $\begin{array}{l}\text { NonAgri. } \\
L^{*} R I\end{array}$ & & $\begin{array}{c}0.00096^{* *} \\
(0.0002)\end{array}$ & $\begin{array}{c}0.00099^{* *} \\
(0.0003)\end{array}$ & $\begin{array}{c}0.0013^{* * *} \\
(0.0002)\end{array}$ & & $\begin{array}{c}0.0009 \\
(0.0006) \\
{[0.131]}\end{array}$ & $\begin{array}{c}0.00096 \\
(0.0006) \\
{[0.119]}\end{array}$ & $\begin{array}{c}0.0013^{* * *} \\
(0.0002)\end{array}$ \\
\hline $\begin{array}{l}\text { Agri. } \\
L^{*} R I\end{array}$ & & $\begin{array}{c}-0.0019^{* *} \\
(0.0005)\end{array}$ & $\begin{array}{c}-0.0019^{* *} \\
(0.0005)\end{array}$ & $\begin{array}{c}-0.0019^{* * *} \\
(0.0004)\end{array}$ & & $\begin{array}{c}-0.0019^{* * *} \\
(0.0003)\end{array}$ & $\begin{array}{c}-0.0019^{* * *} \\
(0.0003)\end{array}$ & $\begin{array}{c}-0.0019^{* * *} \\
(0.0003)\end{array}$ \\
\hline $\begin{array}{l}\text { Business } \\
*_{R I}\end{array}$ & & $\begin{array}{c}-0.0026^{* * *} \\
(0.0004)\end{array}$ & $\begin{array}{c}-0.0025^{* * *} \\
(0.0005)\end{array}$ & $\begin{array}{c}-0.0022^{* * *} \\
(0.0004)\end{array}$ & & $\begin{array}{c}-0.0026^{* * *} \\
(0.0003)\end{array}$ & $\begin{array}{c}-0.0025^{* * *} \\
(0.0003)\end{array}$ & $\begin{array}{c}-0.0022^{* * *} \\
(0.0003)\end{array}$ \\
\hline $\begin{array}{l}\text { LVST } \\
* \mathrm{RI}\end{array}$ & & $\begin{array}{c}0.0005 \\
(0.0003) \\
{[0.12]}\end{array}$ & $\begin{array}{c}0.0005 \\
(0.0003) \\
{[0.137]}\end{array}$ & $\begin{array}{l}0.0006^{*} \\
(0.0003)\end{array}$ & & $\begin{array}{c}0.0006^{* * *} \\
(0.0002)\end{array}$ & $\begin{array}{c}0.0006^{* * *} \\
(0.0002)\end{array}$ & $\begin{array}{c}0.0007^{* * *} \\
(0.0002)\end{array}$ \\
\hline $\log ($ land $)$ & $\begin{array}{l}-0.0111 \\
(0.008)\end{array}$ & $\begin{array}{l}-0.007 \\
(0.008)\end{array}$ & $\begin{array}{l}-0.007 \\
(0.008)\end{array}$ & $\begin{array}{l}-0.002 \\
(0.009)\end{array}$ & $\begin{array}{c}-0.009 \\
(0.0196)\end{array}$ & $\begin{array}{l}-0.007 \\
(0.016)\end{array}$ & $\begin{array}{l}-0.007 \\
(0.016)\end{array}$ & $\begin{array}{l}-0.002 \\
(0.005)\end{array}$ \\
\hline Prop.Lit. & $\begin{array}{l}0.231^{*} \\
(0.109)\end{array}$ & $\begin{array}{c}0.211 \\
(0.109) \\
{[0.111]}\end{array}$ & $\begin{array}{l}0.210 \\
(0.109) \\
{[0.112]}\end{array}$ & $\begin{array}{c}0.183^{*} \\
(0.0812)\end{array}$ & $\begin{array}{c}0.222 \\
(0.155) \\
{[0.151]}\end{array}$ & $\begin{array}{c}0.210 \\
(0.133) \\
{[0.114]}\end{array}$ & $\begin{array}{c}0.210 \\
(0.133) \\
{[0.115]}\end{array}$ & $\begin{array}{c}0.178^{* * *} \\
(0.0512)\end{array}$ \\
\hline Size & $\begin{array}{c}-0.0352 \\
(0.0219) \\
{[0.169]}\end{array}$ & $\begin{array}{c}-0.0370 \\
(0.0202) \\
{[0.127]}\end{array}$ & $\begin{array}{c}-0.0369 \\
(0.0202) \\
{[0.127]}\end{array}$ & $\begin{array}{c}-0.0395 * \\
(0.0182)\end{array}$ & $\begin{array}{c}-0.0343^{* * *} \\
(0.0112)\end{array}$ & $\begin{array}{c}-0.0365^{* * *} \\
(0.0113)\end{array}$ & $\begin{array}{c}-0.0365^{* * *} \\
(0.0113)\end{array}$ & $\begin{array}{c}-0.0391^{* * *} \\
(0.0108)\end{array}$ \\
\hline Split-off & $\begin{array}{c}0.147 \\
(0.0874) \\
{[0.154]}\end{array}$ & $\begin{array}{c}0.137 \\
(0.0783) \\
{[0.141]}\end{array}$ & $\begin{array}{c}0.136 \\
(0.0781) \\
{[0.141]}\end{array}$ & $\begin{array}{c}0.123 \\
(0.0767) \\
{[0.170]}\end{array}$ & $\begin{array}{c}0.155^{* * *} \\
(0.0508)\end{array}$ & $\begin{array}{c}0.142^{* * *} \\
(0.0426)\end{array}$ & $\begin{array}{c}0.142^{* * *} \\
(0.0423)\end{array}$ & $\begin{array}{c}0.134^{* * *} \\
(0.0463)\end{array}$ \\
\hline Migr.(Kag) & $\begin{array}{c}0.147 \\
(0.0769) \\
{[0.114]}\end{array}$ & $\begin{array}{l}0.224^{*} \\
(0.100)\end{array}$ & $\begin{array}{l}0.224^{*} \\
(0.101)\end{array}$ & $\begin{array}{c}0.0847 \\
(0.0954)\end{array}$ & $\begin{array}{c}0.343 \\
(0.303)\end{array}$ & $\begin{array}{c}0.376 \\
(0.310)\end{array}$ & $\begin{array}{c}0.374 \\
(0.312)\end{array}$ & $\begin{array}{c}0.385 \\
(0.475)\end{array}$ \\
\hline $\begin{array}{l}\text { Prop. } \\
\text { Migr.(out) }\end{array}$ & $\begin{array}{c}0.362^{* *} \\
(0.115)\end{array}$ & $\begin{array}{c}0.401^{* *} \\
(0.109)\end{array}$ & $\begin{array}{c}0.400^{* *} \\
(0.109)\end{array}$ & $\begin{array}{c}1.968^{* * *} \\
(0.219)\end{array}$ & $\begin{array}{c}0.432 \\
(1.259)\end{array}$ & $\begin{array}{c}0.362 \\
(1.107)\end{array}$ & $\begin{array}{c}0.357 \\
(1.114)\end{array}$ & $\begin{array}{l}0.394^{*} \\
(0.217)\end{array}$ \\
\hline $\begin{array}{l}\alpha_{t} \\
\text { Cluster D }\end{array}$ & $\begin{array}{c}0.0241 \\
(0.0530)\end{array}$ & $\begin{array}{l}-0.0241 \\
(0.0625)\end{array}$ & $\begin{array}{l}-0.0222 \\
(0.0622)\end{array}$ & $\begin{array}{c}-0.0212 \\
(0.0617) \\
\text { sign. }\end{array}$ & $\begin{array}{l}-0.0165 \\
(0.0709)\end{array}$ & $\begin{array}{l}-0.0527 \\
(0.0586)\end{array}$ & $\begin{array}{l}-0.0506 \\
(0.0598)\end{array}$ & $\begin{array}{c}-0.0408 \\
(0.0526) \\
\text { sign. }\end{array}$ \\
\hline $\begin{array}{l}\text { Obs. } \\
R^{2} \\
\text { F-Test }\end{array}$ & $\begin{array}{c}4104 \\
0.226 \\
102.67^{* * *}\end{array}$ & $\begin{array}{c}4104 \\
0.264 \\
31.05^{* * *}\end{array}$ & $\begin{array}{c}4104 \\
0.264 \\
32.10^{* * *}\end{array}$ & $\begin{array}{c}4104 \\
0.325 \\
13.20^{* * *}\end{array}$ & $\begin{array}{c}3966 \\
0.218 \\
50.74^{* * *}\end{array}$ & $\begin{array}{c}3966 \\
0.259 \\
20.16^{* * *}\end{array}$ & $\begin{array}{c}3966 \\
0.259 \\
20.15^{* * *}\end{array}$ & $\begin{array}{c}3966 \\
0.315 \\
7.53^{* *}\end{array}$ \\
\hline $\begin{array}{l}\text { Anderson } \\
\text { Stock-Yogo } \\
\text { Hansen } \\
\text { (p-value) }\end{array}$ & & & 41 & & $\begin{array}{c}69.85^{* * *} \\
17.68 \\
2.036 \\
(0.36)\end{array}$ & $\begin{array}{c}67.15^{* * *} \\
16.9 \\
5.289^{*} \\
(0.07)\end{array}$ & $\begin{array}{c}66.27^{* * *} \\
16.67 \\
5.328^{*} \\
(0.07)\end{array}$ & $\begin{array}{c}95.39 * * * \\
23.32\end{array}$ \\
\hline
\end{tabular}

Note: ${ }^{* * *} p<0.01,{ }^{* *} p<0.05,{ }^{*} p<0.1$; Between brackets, are included the $p$-value of coefficients closed to significance. Robust standard errors in parentheses and clustered at the 
Table 8: Household Fixed Effect (excl. migrants): Do the effects last overtime?

\begin{tabular}{|c|c|c|c|c|c|c|c|c|}
\hline & $\begin{array}{c}(1) \\
\text { HHFE } \\
\text { split. incl. }\end{array}$ & $\begin{array}{c}(2) \\
\text { HHFE } \\
\text { split. incl. }\end{array}$ & $\begin{array}{c}(3) \\
\text { HHFE } \\
\text { split. incl. }\end{array}$ & $\begin{array}{c}(4) \\
\text { HHFE } \\
\text { split. incl. }\end{array}$ & $\begin{array}{c}(5) \\
\text { HHFE } \\
(2 \mathrm{SLS}) \\
\text { split. incl. }\end{array}$ & $\begin{array}{c}(6) \\
\text { HHFE } \\
(2 \mathrm{SLS}) \\
\text { split. incl. }\end{array}$ & $\begin{array}{c}(7) \\
\text { HHFE } \\
(2 \mathrm{SLS}) \\
\text { split. incl. }\end{array}$ & $\begin{array}{c}(8) \\
\text { HHFE } \\
(2 \mathrm{SLS}) \\
\text { split. incl. }\end{array}$ \\
\hline $\begin{array}{l}\mathrm{RI}(\mathrm{BU}) \\
\mathrm{RI}(\mathrm{BU})^{2}\end{array}$ & $\begin{array}{c}0.0005 \\
(0.0003)\end{array}$ & $\begin{array}{l}0.0005^{*} \\
(0.0002)\end{array}$ & $\begin{array}{c}-0.0017 \\
(0.0018) \\
8.88 \mathrm{e}-06 \\
(6.07 \mathrm{e}-06)\end{array}$ & $\begin{array}{c}-0.0024 \\
(0.0026) \\
\\
1.11 \mathrm{e}-05 \\
(8.79 \mathrm{e}-06)\end{array}$ & $\begin{array}{c}0.0005^{* * *} \\
(0.0002)\end{array}$ & $\begin{array}{c}0.0005^{* * *} \\
(0.0001)\end{array}$ & $\begin{array}{c}-0.0016 \\
(0.0012) \\
{[0.192]} \\
8.31 \mathrm{e}-06^{* *} \\
(4.20 \mathrm{e}-06) \\
\end{array}$ & $\begin{array}{c}-0.0021 \\
(0.0017) \\
1.02 \mathrm{e}-05^{*} \\
(6.11 \mathrm{e}-06)\end{array}$ \\
\hline $\begin{array}{l}\mathrm{RI}(\mathrm{RW}) \\
\mathrm{RI}(\mathrm{RW})^{2}\end{array}$ & $\begin{array}{c}1616 \\
(1739)\end{array}$ & $\begin{array}{l}1593^{*} \\
(726.8)\end{array}$ & $\begin{array}{c}1518^{*} \\
(699.9) \\
\text { dropped }\end{array}$ & $\begin{array}{c}1776 \\
(1193) \\
\text { dropped }\end{array}$ & $\begin{array}{c}1279 \\
(1556)\end{array}$ & $\begin{array}{c}1687 \\
(1498)\end{array}$ & $\begin{array}{c}1695 \\
(1501) \\
\text { dropped }\end{array}$ & $\begin{array}{c}2859 \\
(2594) \\
\text { dropped }\end{array}$ \\
\hline $\begin{array}{l}\text { Crop Sales } \\
\text { *RI(BU) } \\
\text { NonAgri. } \\
\text { L*RI(BU) } \\
\text { Agri. } \\
\text { L*RI(BU) } \\
\text { Business } \\
\text { *RI(BU) } \\
\text { LVST } \\
\text { *RI(BU) } \\
\end{array}$ & & $\begin{array}{c}0.0014^{*} \\
(0.0006) \\
0.0014^{* * *} \\
(0.0002) \\
-0.0019^{* *} \\
(0.0005) \\
-0.0025^{* * *} \\
(0.0003) \\
0.0008^{* *} \\
(0.0003) \\
\end{array}$ & $\begin{array}{c}0.0015^{*} \\
(0.0006) \\
0.0014^{* * *} \\
(0.0002) \\
-0.0018^{* *} \\
(0.0005) \\
-0.0024^{* * *} \\
(0.0004) \\
0.0008^{* *} \\
(0.0003) \\
\end{array}$ & $\begin{array}{c}0.0016^{* *} \\
(0.0006) \\
0.0016^{* * *} \\
(0.0002) \\
-0.0019^{* * *} \\
(0.0004) \\
-0.0023^{* * *} \\
(0.0004) \\
0.0008^{*} \\
(0.0004) \\
\end{array}$ & & $\begin{array}{c}0.0014^{*} \\
(0.0007) \\
0.0014^{* * *} \\
(0.0001) \\
-0.00185^{* * *} \\
(0.0003) \\
-0.0026^{* * *} \\
(0.0003) \\
0.0009^{* * *} \\
(0.0003) \\
\end{array}$ & $\begin{array}{c}0.0015^{* *} \\
(0.0007) \\
0.0015^{* * *} \\
(0.0001) \\
-0.0018^{* * *} \\
(0.0003) \\
-0.0025^{* * *} \\
(0.0003) \\
0.0009^{* * *} \\
(0.0003) \\
\end{array}$ & $\begin{array}{c}0.0014^{* *} \\
(0.0007) \\
0.0016^{* * *} \\
(0.0001) \\
-0.0019^{* * *} \\
(0.0003) \\
-0.0024^{* * *} \\
(0.0003) \\
0.0009^{* *} \\
(0.0004) \\
\end{array}$ \\
\hline $\begin{array}{l}\text { Crop Sales } \\
\text { *RI(RW) }\end{array}$ & & $\begin{array}{l}-8927 \\
(6020)\end{array}$ & $\begin{array}{l}-8908 \\
(6014) \\
{[0.199]}\end{array}$ & $\begin{array}{l}-9195 \\
(5486) \\
{[0.155]}\end{array}$ & & $\begin{array}{l}-8252 \\
(5704) \\
{[0.148]}\end{array}$ & $\begin{array}{l}-8344 \\
(5761) \\
{[0.148]}\end{array}$ & $\begin{array}{c}-9649 * * \\
(4619)\end{array}$ \\
\hline $\begin{array}{l}\text { NonAgri. } \\
L^{*} \mathrm{RI}(\mathrm{RW})\end{array}$ & & $\begin{array}{c}5589 \\
(3807)\end{array}$ & $\begin{array}{c}5617 \\
(3806)\end{array}$ & $\begin{array}{c}5898 \\
(4326)\end{array}$ & & $\begin{array}{c}4975^{* * *} \\
(1411)\end{array}$ & $\begin{array}{c}4892^{* * *} \\
(1400)\end{array}$ & $\begin{array}{l}5781^{* *} \\
(2444)\end{array}$ \\
\hline $\begin{array}{l}\text { Agri. } \\
L^{*} \mathrm{RI}(\mathrm{RW})\end{array}$ & & $\begin{array}{c}-16 \mathrm{e}+06 \\
(8.16 \mathrm{e}+06)\end{array}$ & $\begin{array}{c}-16 \mathrm{e}+06^{*} \\
(8.18 \mathrm{e}+06)\end{array}$ & $\begin{array}{c}-10 \mathrm{e}+06 \\
(6.98 \mathrm{e}+06) \\
{[0.189]}\end{array}$ & & $\begin{array}{c}-16 \mathrm{e}+06^{* * *} \\
(3.76 \mathrm{e}+06)\end{array}$ & $\begin{array}{c}-16 \mathrm{e}+06^{* * *} \\
(3.79 \mathrm{e}+06)\end{array}$ & $\begin{array}{r}-10 \mathrm{e}+06^{* * *} \\
(3.36 \mathrm{e}+06)\end{array}$ \\
\hline $\begin{array}{l}\text { Business } \\
*^{*} \mathrm{RI}(\mathrm{RW}) \\
\mathrm{LVST} \\
{ }^{*} \mathrm{RI}(\mathrm{RW})\end{array}$ & & $\begin{array}{c}-7099 * * * \\
(929.2) \\
7307 * * \\
(2067)\end{array}$ & $\begin{array}{c}-7109^{* * *} \\
(931.6) \\
7306^{* *} \\
(2064)\end{array}$ & $\begin{array}{c}-7414^{* * *} \\
(1175) \\
8068^{* * *} \\
(1607)\end{array}$ & & $\begin{array}{c}-6660^{* *} \\
(3089) \\
6613^{* * *} \\
(2451)\end{array}$ & $\begin{array}{c}-6790^{* *} \\
(3149) \\
6609 * * * \\
(2446)\end{array}$ & $\begin{array}{c}-8191^{* * *} \\
(2668) \\
6784^{* * *} \\
(2586)\end{array}$ \\
\hline Log(land) & $\begin{array}{l}-0.00499 \\
(0.00730)\end{array}$ & $\begin{array}{l}-0.00197 \\
(0.00786)\end{array}$ & $\begin{array}{l}-0.00207 \\
(0.00787)\end{array}$ & $\begin{array}{c}0.00124 \\
(0.00736)\end{array}$ & $\begin{array}{l}-0.00363 \\
(0.00521)\end{array}$ & $\begin{array}{l}-0.00119 \\
(0.00572)\end{array}$ & $\begin{array}{l}-0.00135 \\
(0.00575)\end{array}$ & $\begin{array}{c}0.00114 \\
(0.00428)\end{array}$ \\
\hline Prop.Lit. & $\begin{array}{c}0.184 \\
(0.109)\end{array}$ & $\begin{array}{c}0.171 \\
(0.116)\end{array}$ & $\begin{array}{c}0.170 \\
(0.116)\end{array}$ & $\begin{array}{c}0.154 \\
(0.0908)\end{array}$ & $\begin{array}{c}0.180^{* * *} \\
(0.0694)\end{array}$ & $\begin{array}{l}0.166^{* *} \\
(0.0718)\end{array}$ & $\begin{array}{l}0.165^{* *} \\
(0.0722)\end{array}$ & $\begin{array}{c}0.149 * * * \\
(0.0562)\end{array}$ \\
\hline $\begin{array}{l}\text { Size } \\
\text { Split-off }\end{array}$ & $\begin{array}{c}-0.039 \\
(0.0206) \\
0.122 \\
(0.0830) \\
\end{array}$ & $\begin{array}{c}-0.041^{*} \\
(0.0192) \\
0.112 \\
(0.0738) \\
\end{array}$ & $\begin{array}{c}-0.041^{*} \\
(0.0192) \\
0.111 \\
(0.0733) \\
\end{array}$ & $\begin{array}{c}-0.042^{*} \\
(0.0181) \\
0.104 \\
(0.0784) \\
\end{array}$ & $\begin{array}{c}-0.038^{* * *} \\
(0.0124) \\
0.135^{* * *} \\
(0.0485) \\
\end{array}$ & $\begin{array}{c}-0.041^{* * *} \\
(0.0114) \\
0.114^{* * *} \\
(0.0410)\end{array}$ & $\begin{array}{c}-0.04^{* * *} \\
(0.0114) \\
0.112^{* * *} \\
(0.0401) \\
\end{array}$ & $\begin{array}{c}-0.04^{* * *} \\
(0.0104) \\
0.106^{* * *} \\
(0.0391)\end{array}$ \\
\hline $\begin{array}{l}\text { Migr.(Kag) } \\
\text { Prop. } \\
\text { Migr.(out) }\end{array}$ & $\begin{array}{c}0.151 \\
(0.0888) \\
0.331 \\
(0.185)\end{array}$ & $\begin{array}{l}0.229^{*} \\
(0.106) \\
0.362^{*} \\
(0.178)\end{array}$ & $\begin{array}{l}0.228^{*} \\
(0.107) \\
0.363^{*} \\
(0.177)\end{array}$ & $\begin{array}{c}0.0743 \\
(0.0924) \\
0.361^{*} \\
(0.172)\end{array}$ & $\begin{array}{c}0.270 \\
(0.273) \\
0.190 \\
(0.395)\end{array}$ & $\begin{array}{c}0.324 \\
(0.301) \\
0.394 \\
(0.390)\end{array}$ & $\begin{array}{c}0.322 \\
(0.302) \\
0.415 \\
(0.390)\end{array}$ & $\begin{array}{c}0.303 \\
(0.454) \\
0.486 \\
(0.430)\end{array}$ \\
\hline $\begin{array}{l}\alpha_{t} \\
\text { Cluster D }\end{array}$ & $\begin{array}{c}0.0702 \\
(0.0499)\end{array}$ & $\begin{array}{c}0.0325 \\
(0.0562)\end{array}$ & $\begin{array}{c}0.0355 \\
(0.0548)\end{array}$ & $\begin{array}{c}0.0303 \\
(0.0689) \\
\text { sign. }\end{array}$ & $\begin{array}{c}0.0296 \\
(0.0676)\end{array}$ & $\begin{array}{c}0.0168 \\
(0.0743)\end{array}$ & $\begin{array}{c}0.0223 \\
(0.0763)\end{array}$ & $\begin{array}{c}0.0308 \\
(0.0446) \\
\text { sign. }\end{array}$ \\
\hline $\begin{array}{l}\text { Obs. } \\
R^{2} \\
\text { F-Test }\end{array}$ & $\begin{array}{c}3803 \\
0.185 \\
434.45^{* * *}\end{array}$ & $\begin{array}{c}3803 \\
0.228 \\
16227.20^{\text {*** }}\end{array}$ & $\begin{array}{c}3803 \\
0.228 \\
28238.60^{* * *}\end{array}$ & $\begin{array}{c}3803 \\
0.288 \\
106.68^{* * *}\end{array}$ & $\begin{array}{c}3674 \\
0.181 \\
24.80^{* * *}\end{array}$ & $\begin{array}{c}3674 \\
0.226 \\
245.58^{* * *}\end{array}$ & $\begin{array}{c}3674 \\
0.226 \\
190.63^{* * *}\end{array}$ & $\begin{array}{c}3674 \\
0.280 \\
110.57^{* * *}\end{array}$ \\
\hline
\end{tabular}

$R I(B U)$ represents the $R I$ index, restricted to the refugees from Burundi while $R I(R W)$ cor-

responds to the RI index restricted to the refugee4damps, populated of refugees from Rwanda.

${ }^{* * *} p<0.01,{ }^{* *} p<0.05,{ }^{*} p<0.1$; Between brackets, are included the $p$-value of coefficients closed to significance. Robust standard errors in parentheses and clustered at the district level. The activity variables are not presented but give similar results than previous tables. 
Table 9: Choice of location for refugee camps?

\begin{tabular}{|c|c|c|c|c|c|c|c|c|}
\hline & (1) & (2) & (3) & (4) & (5) & (6) & (7) & (8) \\
\hline \multirow[t]{2}{*}{$\begin{array}{l}\text { PART A } \\
\text { Sample }\end{array}$} & All & All & All & All & All & All & All & All \\
\hline & RI & $\mathrm{RI}^{2}$ & $\mathrm{RI}$ (closest) & $\mathrm{RI}(\text { closest })^{2}$ & Space & Space $^{2}$ & Scale & Scale $^{2}$ \\
\hline \multirow{6}{*}{$\begin{array}{l}\text { Crop Sales } \\
(1991) \\
\text { NonAgri.L } \\
(1991) \\
\text { Agri. L } \\
(1991)\end{array}$} & -4.709 & -1362 & -4.545 & -1278 & $-3.24 \mathrm{e}-05$ & $-8.46 \mathrm{e}-08$ & -240.2 & $-1.85 e+08$ \\
\hline & $(5.216)$ & -1491 & $(5.038)$ & -1399 & $(3.71 \mathrm{e}-05)$ & $(9.30 \mathrm{e}-08)$ & -3391 & $(3.81 \mathrm{e}+08)$ \\
\hline & 1.264 & 253.1 & 1.236 & 238.5 & $1.38 \mathrm{e}-05$ & $2.03 \mathrm{e}-08$ & -1317 & $-1.36 e+08$ \\
\hline & $(1.905)$ & $(436.2)$ & $(1.855)$ & (410.3) & $(1.85 \mathrm{e}-05)$ & $(3.16 \mathrm{e}-08)$ & -3229 & $(3.02 \mathrm{e}+08)$ \\
\hline & 0.462 & -170.4 & 0.487 & -157.4 & $1.66 \mathrm{e}-05$ & $5.05 \mathrm{e}-11$ & 1935 & $1.63 \mathrm{e}+08$ \\
\hline & $(1.200)$ & $(433.5)$ & (1.164) & (405.3) & $(1.63 \mathrm{e}-05)$ & $(2.20 \mathrm{e}-08)$ & -3816 & $(3.01 \mathrm{e}+08)$ \\
\hline \multirow{2}{*}{$\begin{array}{l}\text { Business } \\
\text { (1991) }\end{array}$} & -4.862 & -1111 & -4.733 & -1045 & $-4.63 e-05$ & $-7.87 \mathrm{e}-08$ & -2397 & $-3.56 \mathrm{e}+08$ \\
\hline & $(5.544)$ & $(1271)$ & $(5.397)$ & (1195) & $(5.27 \mathrm{e}-05)$ & $(8.98 \mathrm{e}-08)$ & $(5601)$ & $(5.46 \mathrm{e}+08)$ \\
\hline \multirow{2}{*}{$\begin{array}{l}\text { LVST } \\
(1991)\end{array}$} & 5.983 & 1369 & 5.824 & 1287 & $5.71 \mathrm{e}-05$ & $9.78 \mathrm{e}-08$ & 11493 & $9.72 \mathrm{e}+08$ \\
\hline & $(5.405)$ & $(1244)$ & $(5.261)$ & $(1170)$ & $(5.13 \mathrm{e}-05)$ & $(8.87 \mathrm{e}-08)$ & $(5770)$ & $(5.65 \mathrm{e}+08)$ \\
\hline \multirow{2}{*}{$\begin{array}{l}\text { Log(land) } \\
\text { (1991) }\end{array}$} & -0.431 & -121.3 & -0.417 & -113.9 & $-3.11 \mathrm{e}-06$ & $-7.70 \mathrm{e}-09$ & -719.1 & $-35.39 e+06$ \\
\hline & $(0.582)$ & $(156.1)$ & $(0.563)$ & $(146.5)$ & $(4.62 \mathrm{e}-06)$ & $(1.01 \mathrm{e}-08)$ & $(600.1)$ & $(2.27 \mathrm{e}+07)$ \\
\hline \multirow{2}{*}{$\begin{array}{l}\text { Prop.Lit. } \\
\text { (1991) }\end{array}$} & -10.10 & -2144 & -9.856 & -2018 & -0.000104 & $-1.60 \mathrm{e}-07$ & $-20187^{*}$ & $-14.63 \mathrm{e}+08^{*}$ \\
\hline & $(9.147)$ & -1924 & (8.928) & -1811 & $(9.48 \mathrm{e}-05)$ & $(1.44 \mathrm{e}-07)$ & -9167 & $(6.59 \mathrm{e}+08)$ \\
\hline \multirow{2}{*}{$\begin{array}{l}\text { Size } \\
(1991)\end{array}$} & 0.0967 & 49.26 & 0.0905 & 46.05 & $-2.81 \mathrm{e}-07$ & $2.30 \mathrm{e}-09$ & -126.1 & $-17.77 \mathrm{e}+06$ \\
\hline & $(0.207)$ & $(74.76)$ & $(0.198)$ & $(70.01)$ & $(1.05 \mathrm{e}-06)$ & $(4.07 \mathrm{e}-09)$ & $(455.2)$ & $(3.39 \mathrm{e}+07)$ \\
\hline \multirow{2}{*}{$\begin{array}{l}\text { Prop. (1991) } \\
\text { Migr.(out) }\end{array}$} & -1.794 & -469.6 & -1.737 & -439.6 & $-1.36 \mathrm{e}-05$ & $-2.49 \mathrm{e}-08$ & 10430 & $5.54 \mathrm{e}+08$ \\
\hline & $(3.875)$ & $(928.8)$ & $(3.765)$ & $(871.8)$ & $(3.47 \mathrm{e}-05)$ & $(5.96 \mathrm{e}-08)$ & -9742 & $(5.58 \mathrm{e}+08)$ \\
\hline \multirow{2}{*}{$\begin{array}{l}\log (\text { ConsPAE }) \\
(1991)\end{array}$} & -8.301 & -1815 & -8.091 & -1707 & $-8.25 \mathrm{e}-05$ & $-1.30 \mathrm{e}-07$ & -10719 & $-9.59 e+08$ \\
\hline & $(7.318)$ & $(1610)$ & $(7.132)$ & $(1514)$ & $(7.23 \mathrm{e}-05)$ & $(1.15 \mathrm{e}-07)$ & $(6729)$ & $(6.66 \mathrm{e}+08)$ \\
\hline \multirow{2}{*}{$\begin{array}{l}\text { Constant } \\
\text { (1991) }\end{array}$} & 117.3 & 25866 & 114.3 & 24327 & 0.00116 & $1.85 \mathrm{e}-06$ & 160085 & $1.39 \mathrm{e}+10$ \\
\hline & $(105.7)$ & -23480 & $(103.0)$ & -22081 & $(0.00104)$ & $(1.67 \mathrm{e}-06)$ & -95963 & $(9.37 \mathrm{e}+09)$ \\
\hline \multirow{2}{*}{$\begin{array}{l}\text { Observations } \\
\text { R-squared }\end{array}$} & 1888 & 1888 & 1888 & 1888 & 1888 & 1888 & 1888 & 1888 \\
\hline & 0.041 & 0.032 & 0.042 & 0.032 & 0.053 & 0.037 & 0.114 & 0.069 \\
\hline \multirow{3}{*}{$\begin{array}{l}\text { PART B } \\
\text { Sample }\end{array}$} & & & & & & & & \\
\hline & $\begin{array}{c}\text { Karagwe } \\
\text { Ngara }\end{array}$ & $\begin{array}{l}\text { Karagwe } \\
\text { Ngara }\end{array}$ & $\begin{array}{l}\text { Karagwe } \\
\text { Ngara }\end{array}$ & $\begin{array}{l}\text { Karagwe } \\
\text { Ngara }\end{array}$ & $\begin{array}{l}\text { Karagwe } \\
\text { Ngara }\end{array}$ & $\begin{array}{l}\text { Karagwe } \\
\text { Ngara }\end{array}$ & $\begin{array}{l}\text { Karagwe } \\
\text { Ngara }\end{array}$ & $\begin{array}{l}\text { Karagwe } \\
\text { Ngara }\end{array}$ \\
\hline & RI & $\mathrm{RI}^{2}$ & RI(closest) & $\mathrm{RI}(\text { closest })^{2}$ & Space & Space $^{2}$ & Scale & Scale $^{2}$ \\
\hline \multirow{4}{*}{$\begin{array}{l}\text { Crop Sales } \\
(1991) \\
\text { Non Agri.L } \\
(1991)\end{array}$} & -26.09 & -7302 & -25.21 & -6852 & -0.000190 & $-4.57 \mathrm{e}-07$ & -17997 & $-22.25 \mathrm{e}+08$ \\
\hline & $(14.81)$ & -4754 & (14.23) & -4456 & $(8.09 \mathrm{e}-05)$ & $(2.76 \mathrm{e}-07)$ & -4903 & $(8.81 \mathrm{e}+08)$ \\
\hline & -5.308 & -1216 & -5.169 & -1144 & $-5.07 \mathrm{e}-05$ & $-8.84 \mathrm{e}-08$ & $-13611^{*}$ & $-16.92 \mathrm{e}+08$ \\
\hline & $(4.227)$ & $(881.8)$ & $(4.127)$ & $(830.7)$ & $(4.48 \mathrm{e}-05)$ & $(6.92 \mathrm{e}-08)$ & -1847 & $(4.95 \mathrm{e}+08)$ \\
\hline \multirow{2}{*}{$\begin{array}{l}\text { Agri. L } \\
(1991)\end{array}$} & -6.870 & -3263 & -6.458 & -3051 & $9.37 \mathrm{e}-06$ & $-1.56 \mathrm{e}-07$ & 12577 & $8.27 \mathrm{e}+08$ \\
\hline & (9.923) & -3499 & $(9.492)$ & -3278 & $(4.01 \mathrm{e}-05)$ & $(1.93 \mathrm{e}-07)$ & -3159 & $(7.24 \mathrm{e}+08)$ \\
\hline \multirow{2}{*}{$\begin{array}{l}\text { Business } \\
(1991)\end{array}$} & -25.38 & -5960 & -24.68 & -5602 & -0.000234 & $-4.12 \mathrm{e}-07$ & -2656 & $-50.67 \mathrm{e}+06$ \\
\hline & $(33.01)$ & -7701 & $(32.11)$ & -7240 & $(0.000307)$ & $(5.37 \mathrm{e}-07)$ & -3078 & $(2.16 \mathrm{e}+07)$ \\
\hline \multirow{2}{*}{$\begin{array}{l}\text { LVST } \\
(1991)\end{array}$} & 7.504 & 2096 & 7.256 & 1968 & $5.53 \mathrm{e}-05$ & $1.36 \mathrm{e}-07$ & -53.15 & $1.58 \mathrm{e}+08$ \\
\hline & (12.13) & -2963 & (11.78) & -2785 & $(0.000108)$ & $(2.06 \mathrm{e}-07)$ & -7089 & $(8.40 \mathrm{e}+08)$ \\
\hline \multirow{2}{*}{$\begin{array}{l}\text { Log(land) } \\
(1991)\end{array}$} & -3.992 & -1062 & -3.866 & -997.5 & $-3.16 \mathrm{e}-05$ & $-6.96 \mathrm{e}-08$ & 301.6 & $-3.51 \mathrm{e}+06$ \\
\hline & $(7.424)$ & -1859 & $(7.206)$ & -1747 & $(6.38 \mathrm{e}-05)$ & $(1.26 \mathrm{e}-07)$ & -1984 & $(2.36 \mathrm{e}+08)$ \\
\hline \multirow{2}{*}{$\begin{array}{l}\text { Prop.Lit. } \\
\text { (1991) }\end{array}$} & -20.73 & -3786 & -20.32 & -3571 & -0.000240 & $-3.15 \mathrm{e}-07$ & -10989 & $-6.65 e+08$ \\
\hline & $(10.58)$ & -1339 & $(10.45)$ & -1272 & $(0.000149)$ & $(1.49 \mathrm{e}-07)$ & -2159 & $(2.52 \mathrm{e}+08)$ \\
\hline Size & 0.863 & 375.7 & 0.816 & 351.6 & $3.44 \mathrm{e}-07$ & $1.90 \mathrm{e}-08$ & -2414 & $-2.005 \mathrm{e}+08^{* *}$ \\
\hline (1991) & $(2.038)$ & $(627.7)$ & $(1.962)$ & $(588.7)$ & $(1.23 \mathrm{e}-05)$ & $(3.75 \mathrm{e}-08)$ & $(544.6)$ & $(6.53 \mathrm{e}+06)$ \\
\hline Prop. (1991) & -13.44 & -4313 & -12.90 & -4035 & $-6.77 \mathrm{e}-05$ & $-2.14 \mathrm{e}-07$ & 17414 & $1.98 \mathrm{e}+09$ \\
\hline Migr.(out) & $(22.87)$ & -5281 & $(22.24)$ & -4957 & $(0.000210)$ & $(3.37 \mathrm{e}-07)$ & -17753 & $(1.43 \mathrm{e}+09)$ \\
\hline $\log ($ ConsPAE $)$ & -18.63 & -4157 & -18.15 & -3908 & -0.000181 & $-2.92 \mathrm{e}-07$ & $-18832 * * *$ & $-17.76 \mathrm{e}+08^{*}$ \\
\hline (1991) & $(7.244)$ & -1811 & (7.028) & -1700 & $(6.10 \mathrm{e}-05)$ & $(1.14 \mathrm{e}-07)$ & $(248.5)$ & $(1.62 \mathrm{e}+08)$ \\
\hline Constant & 312.9 & 70798 & 304.6 & 66562 & 0.00300 & $4.96 \mathrm{e}-06$ & 289739 & $2.77 \mathrm{e}+10^{*}$ \\
\hline & (191.3) & -46337 & $(185.9)$ & -43528 & $(0.00170)$ & $(3.09 \mathrm{e}-06)$ & -57175 & $(4.20 \mathrm{e}+09)$ \\
\hline Observations & 475 & 475 & 47543 & 475 & 475 & 475 & 475 & 475 \\
\hline R-squared & 0.110 & 0.094 & 0.110 & 0.094 & 0.132 & 0.102 & 0.178 & 0.119 \\
\hline
\end{tabular}

Note: ${ }^{* * *} p<0.01,{ }^{* *} p<0.05,{ }^{*} p<0.1$; Robust standard errors in parentheses and clustered

at the district level. 
Table 10: Household Fixed Effect (excl. migrants) with alternative treatment variables

\begin{tabular}{|c|c|c|c|c|c|c|}
\hline & $\begin{array}{c}1) \\
\text { HHFE } \\
(2 \mathrm{SLS})\end{array}$ & $\begin{array}{c}(2) \\
\text { HHFE } \\
(2 \mathrm{SLS})\end{array}$ & $\begin{array}{c}(3) \\
\text { HHFE } \\
(2 \mathrm{SLS})\end{array}$ & $\begin{array}{c}(4) \\
\text { HHFE } \\
(2 \mathrm{SLS})\end{array}$ & $\begin{array}{c}(5) \\
\text { HHFE } \\
(2 \mathrm{SLS})\end{array}$ & $\begin{array}{c}(6) \\
\text { HHFE } \\
(2 \mathrm{SLS})\end{array}$ \\
\hline \multirow[t]{2}{*}{ Treat } & $\mathrm{RC}$ & $\mathrm{RC}$ & $\mathrm{RC}$ & RI(closest) & $\mathrm{RI}($ closest $)$ & $\mathrm{RI}$ (closest) \\
\hline & split. incl. & split. incl. & split. incl. & split. incl. & split. incl. & split. incl. \\
\hline Treat & $\begin{array}{l}-0.0161 \\
(0.0600)\end{array}$ & $\begin{array}{l}0.000133 \\
(0.0605)\end{array}$ & $\begin{array}{l}-0.0261 \\
(0.0482)\end{array}$ & $\begin{array}{c}0.000533^{* * *} \\
(0.000191)\end{array}$ & $\begin{array}{l}-0.00158 \\
(0.00122)\end{array}$ & $\begin{array}{l}-0.00222 \\
(0.00175)\end{array}$ \\
\hline Treat $^{2}$ & & & & & $\begin{array}{c}{[0.195]} \\
8.61 \mathrm{e}-06^{* *} \\
(4.32 \mathrm{e}-06)\end{array}$ & $\begin{array}{l}1.09 \mathrm{e}-05^{*} \\
(6.31 \mathrm{e}-06)\end{array}$ \\
\hline Crop Sales & & $\begin{array}{l}-0.0473 \\
(0.0397)\end{array}$ & $\begin{array}{l}-0.0406 \\
(0.0447)\end{array}$ & & $\begin{array}{l}-0.0326 \\
(0.0364)\end{array}$ & $\begin{array}{l}-0.0254 \\
(0.0421)\end{array}$ \\
\hline NonAgri.L & & $\begin{array}{l}0.218^{* * *} \\
(0.0299)\end{array}$ & $\begin{array}{l}0.189^{* * *} \\
(0.0384)\end{array}$ & & $\begin{array}{l}0.198^{* * *} \\
(0.0317)\end{array}$ & $\begin{array}{l}0.168^{* * *} \\
(0.0351)\end{array}$ \\
\hline Agri. L & & $\begin{array}{c}0.151^{* * *} \\
(0.0390)\end{array}$ & $\begin{array}{c}0.146^{* * *} \\
(0.0407)\end{array}$ & & $\begin{array}{c}0.140^{* * *} \\
(0.0454)\end{array}$ & $\begin{array}{c}0.135^{* * *} \\
(0.0473)\end{array}$ \\
\hline Business & & $\begin{array}{c}0.273^{* * *} \\
(0.0795)\end{array}$ & $\begin{array}{c}0.271^{* * *} \\
(0.0739)\end{array}$ & & $\begin{array}{l}0.266^{* * *} \\
(0.0761)\end{array}$ & $\begin{array}{l}0.263^{* * *} \\
(0.0703)\end{array}$ \\
\hline LVST & & $\begin{array}{c}0.0215 \\
(0.0574)\end{array}$ & $\begin{array}{c}0.0244 \\
(0.0544)\end{array}$ & & $\begin{array}{c}0.0158 \\
(0.0550) \\
\end{array}$ & $\begin{array}{c}0.0177 \\
(0.0529) \\
\end{array}$ \\
\hline Crop Sales & & $0.181^{* *}$ & $0.184^{* * *}$ & & $0.00153^{* *}$ & $0.00150^{* *}$ \\
\hline *Treat & & $(0.0725)$ & $(0.0455)$ & & $(0.000718)$ & $(0.000728)$ \\
\hline NonAgri. & & -0.0770 & $-0.0849^{*}$ & & $0.00151^{* * *}$ & $0.00169^{* * *}$ \\
\hline $\mathrm{L}^{*}$ Treat & & $(0.0498)$ & $(0.0448)$ & & $(0.000149)$ & $(0.000125)$ \\
\hline Agri. & & -0.141 & -0.149 & & $-0.00184^{* * *}$ & $-0.00194^{* * *}$ \\
\hline$L^{*}$ Treat & & $\begin{array}{c}(0.0975) \\
{[0.148]}\end{array}$ & $\begin{array}{l}(0.102) \\
{[0.147]}\end{array}$ & & $(0.000292)$ & $(0.000304)$ \\
\hline Business & & -0.0971 & -0.0790 & & $-0.00257^{* * *}$ & $-0.00252^{* * *}$ \\
\hline *Treat & & $(0.0997)$ & $(0.0733)$ & & $(0.000325)$ & $(0.000343)$ \\
\hline LVST & & -0.0454 & -0.0437 & & $0.000894^{* * *}$ & $0.000944^{* *}$ \\
\hline${ }^{*}$ Treat & & $(0.0849)$ & $(0.0790)$ & & $(0.000298)$ & $(0.000378)$ \\
\hline $\log ($ land $)$ & $\begin{array}{l}-0.00362 \\
(0.00520)\end{array}$ & $\begin{array}{l}-0.00123 \\
(0.00573)\end{array}$ & $\begin{array}{c}0.00113 \\
(0.00444)\end{array}$ & $\begin{array}{l}-0.00361 \\
(0.00522)\end{array}$ & $\begin{array}{l}-0.00122 \\
(0.00576)\end{array}$ & $\begin{array}{c}0.00122 \\
(0.00428)\end{array}$ \\
\hline Prop.Lit. & $\begin{array}{l}0.179^{* *} \\
(0.0703)\end{array}$ & $\begin{array}{l}0.165^{* *} \\
(0.0697)\end{array}$ & $\begin{array}{c}0.145^{* * *} \\
(0.0549)\end{array}$ & $\begin{array}{c}0.180^{* * *} \\
(0.0693)\end{array}$ & $\begin{array}{l}0.165^{* *} \\
(0.0716)\end{array}$ & $\begin{array}{c}0.148^{* * *} \\
(0.0562)\end{array}$ \\
\hline Size & $\begin{array}{c}-0.0380^{* * *} \\
(0.0123)\end{array}$ & $\begin{array}{c}-0.0408^{* * *} \\
(0.0113)\end{array}$ & $\begin{array}{c}-0.0419^{* * *} \\
(0.0103)\end{array}$ & $\begin{array}{c}-0.0379^{* * *} \\
(0.0124)\end{array}$ & $\begin{array}{c}-0.0405^{* * *} \\
(0.0114)\end{array}$ & $\begin{array}{c}-0.0417^{* * *} \\
(0.0104)\end{array}$ \\
\hline Split-off & $\begin{array}{c}0.135^{* * *} \\
(0.0486) \\
\end{array}$ & $\begin{array}{c}0.116^{* * *} \\
(0.0385)\end{array}$ & $\begin{array}{c}0.110^{* * *} \\
(0.0373)\end{array}$ & $\begin{array}{c}0.135^{* * *} \\
(0.0485)\end{array}$ & $\begin{array}{c}0.114^{* * *} \\
(0.0406)\end{array}$ & $\begin{array}{c}0.107^{* * *} \\
(0.0392) \\
\end{array}$ \\
\hline Migr.(Kag) & $\begin{array}{c}0.206 \\
(0.381)\end{array}$ & $\begin{array}{c}0.385 \\
(0.377)\end{array}$ & $\begin{array}{c}0.476 \\
(0.411)\end{array}$ & $\begin{array}{c}0.187 \\
(0.392)\end{array}$ & $\begin{array}{c}0.404 \\
(0.387)\end{array}$ & $\begin{array}{c}0.483 \\
(0.428)\end{array}$ \\
\hline $\begin{array}{l}\text { Prop. } \\
\text { Migr.(out) }\end{array}$ & $\begin{array}{c}0.263 \\
(0.269)\end{array}$ & $\begin{array}{c}0.319 \\
(0.295)\end{array}$ & $\begin{array}{c}0.317 \\
(0.427)\end{array}$ & $\begin{array}{c}0.272 \\
(0.271)\end{array}$ & $\begin{array}{c}0.334 \\
(0.295)\end{array}$ & $\begin{array}{c}0.313 \\
(0.447)\end{array}$ \\
\hline $\begin{array}{l}\alpha_{t} \\
\text { Cluster D }\end{array}$ & $\begin{array}{c}0.0406 \\
(0.0634)\end{array}$ & $\begin{array}{c}0.0215 \\
(0.0772)\end{array}$ & $\begin{array}{c}0.0374 \\
(0.0472) \\
\text { sign. }\end{array}$ & $\begin{array}{c}0.0298 \\
(0.0681)\end{array}$ & $\begin{array}{c}0.0172 \\
(0.0756)\end{array}$ & $\begin{array}{c}0.0286 \\
(0.0446) \\
\text { sign. }\end{array}$ \\
\hline Obs. & 3674 & 3674 & 3674 & 3674 & 3674 & 3674 \\
\hline$R^{2}$ & 0.181 & 0.225 & 0.278 & 0.181 & 0.224 & 0.278 \\
\hline F-Test & $3.66^{*}$ & 1.42 & $4.17^{*}$ & $53.65^{* * *}$ & $7.20^{* *}$ & $4.79^{*}$ \\
\hline
\end{tabular}

${ }^{* * *} p<0.01,{ }^{* *} p<0.05,{ }^{*} p<0.1$; Between brackets, are included the p-value of coefficients closed to significance. Robust standard errors in parentheses and clustered at the district level. $R C$ is a dummy variable indicating whether the 4 qommunity leader has replied positively to the question "Were there any refugee settlement closed by?". RI(Closest) is similar to the RI index but restricted to the closest refugee camp. 
Table 11: Household Fixed Effect (excl. migrants) with alternative treatment variables

\begin{tabular}{|c|c|c|c|c|c|c|}
\hline & $\begin{array}{c}(1) \\
\text { HHFE } \\
(2 \mathrm{SLS})\end{array}$ & $\begin{array}{c}(2) \\
\text { HHFE } \\
(2 \mathrm{SLS})\end{array}$ & $\begin{array}{c}(3) \\
\text { HHFE } \\
(2 \mathrm{SLS})\end{array}$ & $\begin{array}{c}(4) \\
\text { HHFE } \\
(2 \mathrm{SLS})\end{array}$ & $\begin{array}{c}(5) \\
\text { HHFE } \\
(2 \mathrm{SLS})\end{array}$ & $\begin{array}{c}(6) \\
\text { HHFE } \\
(2 \mathrm{SLS})\end{array}$ \\
\hline Treat & Space & Space & Space & Scale & Scale & Scale \\
\hline $\begin{array}{l}\text { Treat } \\
\text { Treat }^{2}\end{array}$ & $\begin{array}{l}53.72 * * \\
(25.85)\end{array}$ & $\begin{array}{c}-120.1 \\
(83.68) \\
{[0.151]} \\
85469 * * * \\
-32287 \\
\end{array}$ & $\begin{array}{c}-161.5 \\
(118.9) \\
{[0.174]} \\
101389 * * \\
-47077 \\
\end{array}$ & $\begin{array}{c}-1.20 \mathrm{e}-06 \\
(9.72 \mathrm{e}-07)\end{array}$ & $\begin{array}{c}-5.41 \mathrm{e}-06^{* * *} \\
(1.76 \mathrm{e}-06) \\
4.17 \mathrm{e}-11^{* * *} \\
(1.55 \mathrm{e}-11) \\
\end{array}$ & $\begin{array}{c}-5.04 \mathrm{e}-06^{* * *} \\
(1.87 \mathrm{e}-06) \\
4.09 \mathrm{e}-11^{* *} \\
(1.65 \mathrm{e}-11)\end{array}$ \\
\hline Crop Sales & & $\begin{array}{l}-0.0329 \\
(0.0364)\end{array}$ & $\begin{array}{l}-0.0256 \\
(0.0421)\end{array}$ & & $\begin{array}{l}-0.0362 \\
(0.0305)\end{array}$ & $\begin{array}{l}-0.0302 \\
(0.0353)\end{array}$ \\
\hline NonAgri.L & & $\begin{array}{c}0.196^{* * *} \\
(0.0316)\end{array}$ & $\begin{array}{c}0.166^{* * *} \\
(0.0351)\end{array}$ & & $\begin{array}{c}0.189 * * * \\
(0.0312)\end{array}$ & $\begin{array}{c}0.162^{* * *} \\
(0.0343)\end{array}$ \\
\hline Agri. L & & $\begin{array}{c}0.139 * * * \\
(0.0457)\end{array}$ & $\begin{array}{c}0.133^{* * *} \\
(0.0475)\end{array}$ & & $\begin{array}{c}0.153^{* * *} \\
(0.0371)\end{array}$ & $\begin{array}{c}0.147^{* * *} \\
(0.0390)\end{array}$ \\
\hline Business & & $\begin{array}{c}0.268^{* * *} \\
(0.0760)\end{array}$ & $\begin{array}{c}0.265^{* * * *} \\
(0.0700)\end{array}$ & & $\begin{array}{c}0.266^{* * *} \\
(0.0712)\end{array}$ & $\begin{array}{c}0.262^{* * *} \\
(0.0663)\end{array}$ \\
\hline LVST & & $\begin{array}{c}0.0150 \\
(0.0555)\end{array}$ & $\begin{array}{c}0.0166 \\
(0.0535)\end{array}$ & & $\begin{array}{c}0.000562 \\
(0.0564)\end{array}$ & $\begin{array}{l}0.00604 \\
(0.0570)\end{array}$ \\
\hline $\begin{array}{l}\text { Crop Sales } \\
\text { *Treat } \\
\text { NonAgri. } \\
\text { L*Treat }\end{array}$ & & $\begin{array}{c}180.2^{* * *} \\
(68.28) \\
202.3^{* * *} \\
(18.76)\end{array}$ & $\begin{array}{c}174.5^{* * *} \\
(67.34) \\
226.6^{* * *} \\
(25.95)\end{array}$ & & $\begin{array}{c}2.09 \mathrm{e}-06 * * \\
(8.84 \mathrm{e}-07) \\
5.46 \mathrm{e}-07 \\
(6.76 \mathrm{e}-07)\end{array}$ & $\begin{array}{c}2.45 \mathrm{e}-06^{* * *} \\
(6.33 \mathrm{e}-07) \\
5.66 \mathrm{e}-07 \\
(4.31 \mathrm{e}-07) \\
{[0.190]}\end{array}$ \\
\hline $\begin{array}{l}\text { Agri. } \\
\text { L*Treat }^{*} \text { Tre }\end{array}$ & & $\begin{array}{c}-134.7^{* * *} \\
(38.22)\end{array}$ & $\begin{array}{c}-144.3^{* * *} \\
(41.62)\end{array}$ & & $\begin{array}{c}-2.87 \mathrm{e}-06 * \\
(1.48 \mathrm{e}-06)\end{array}$ & $\begin{array}{c}-3.22 \mathrm{e}-06 \\
(2.05 \mathrm{e}-06) \\
{[0.116]}\end{array}$ \\
\hline $\begin{array}{l}\text { Business } \\
{ }^{*} \text { Treat }\end{array}$ & & $\begin{array}{c}-286.9 * * * \\
(39.43)\end{array}$ & $\begin{array}{c}-280.8^{* * *} \\
(41.09)\end{array}$ & & $\begin{array}{c}-1.90 \mathrm{e}-06^{* * *} \\
(5.26 \mathrm{e}-07)\end{array}$ & $\begin{array}{c}-1.84 \mathrm{e}-06 * * * \\
(4.16 \mathrm{e}-07)\end{array}$ \\
\hline $\begin{array}{l}\text { LVST } \\
*_{\text {Treat }}\end{array}$ & & $\begin{array}{c}103.4^{* * *} \\
(37.28)\end{array}$ & $\begin{array}{c}111.8^{* *} \\
(48.21)\end{array}$ & & $\begin{array}{l}1.15 \mathrm{e}-06^{*} \\
(6.52 \mathrm{e}-07)\end{array}$ & $\begin{array}{c}9.63 \mathrm{e}-07 \\
(7.24 \mathrm{e}-07) \\
{[0.183]}\end{array}$ \\
\hline $\log ($ land $)$ & $\begin{array}{l}-0.00356 \\
(0.00525)\end{array}$ & $\begin{array}{c}-0.00119 \\
(0.00577)\end{array}$ & $\begin{array}{c}0.00123 \\
(0.00429)\end{array}$ & $\begin{array}{l}-0.00384 \\
(0.00506)\end{array}$ & $\begin{array}{l}-0.00198 \\
(0.00535)\end{array}$ & $\begin{array}{l}0.000674 \\
(0.00432)\end{array}$ \\
\hline Prop.Lit. & $\begin{array}{c}0.180 * * * \\
(0.0694)\end{array}$ & $\begin{array}{l}0.163^{* *} \\
(0.0720)\end{array}$ & $\begin{array}{l}0.146^{* *} \\
(0.0570)\end{array}$ & $\begin{array}{l}0.177^{* *} \\
(0.0700)\end{array}$ & $\begin{array}{l}0.166^{* *} \\
(0.0747)\end{array}$ & $\begin{array}{l}0.147 * * \\
(0.0588)\end{array}$ \\
\hline Size & $\begin{array}{c}-0.0379 * * * \\
(0.0124)\end{array}$ & $\begin{array}{c}-0.0404^{* * *} \\
(0.0114)\end{array}$ & $\begin{array}{c}-0.0416^{* * *} \\
(0.0104)\end{array}$ & $\begin{array}{c}-0.0379 * * * \\
(0.0124)\end{array}$ & $\begin{array}{c}-0.0403^{* * *} \\
(0.0114)\end{array}$ & $\begin{array}{c}-0.0418^{* * *} \\
(0.0102)\end{array}$ \\
\hline Split-off & $\begin{array}{c}0.135^{* * *} \\
(0.0485)\end{array}$ & $\begin{array}{c}0.113^{* * *} \\
(0.0405)\end{array}$ & $\begin{array}{c}0.107^{* * *} \\
(0.0388)\end{array}$ & $\begin{array}{c}0.132 * * * \\
(0.0466)\end{array}$ & $\begin{array}{c}0.112^{* * *} \\
(0.0383)\end{array}$ & $\begin{array}{c}0.102^{* * *} \\
(0.0367)\end{array}$ \\
\hline $\begin{array}{l}\text { Migr.(Kag) } \\
\text { Prop. } \\
\text { Migr.(out) }\end{array}$ & $\begin{array}{c}0.185 \\
(0.392) \\
0.273 \\
(0.272)\end{array}$ & $\begin{array}{c}0.404 \\
(0.388) \\
0.337 \\
(0.294) \\
\end{array}$ & $\begin{array}{c}0.481 \\
(0.428) \\
0.322 \\
(0.442)\end{array}$ & $\begin{array}{c}0.244 \\
(0.395) \\
0.258 \\
(0.266)\end{array}$ & $\begin{array}{c}0.390 \\
(0.345) \\
0.291 \\
(0.277)\end{array}$ & $\begin{array}{c}0.457 \\
(0.367) \\
0.244 \\
(0.361)\end{array}$ \\
\hline $\begin{array}{l}\alpha_{t} \\
\text { Cluster D }\end{array}$ & $\begin{array}{c}0.0291 \\
(0.0685)\end{array}$ & $\begin{array}{c}0.0166 \\
(0.0758)\end{array}$ & $\begin{array}{c}0.0281 \\
(0.0449) \\
\text { sign. }\end{array}$ & $\begin{array}{c}0.0604 \\
(0.0655)\end{array}$ & $\begin{array}{c}0.0580 \\
(0.0779)\end{array}$ & $\begin{array}{c}0.0631 \\
(0.0508) \\
\text { sign. }\end{array}$ \\
\hline $\begin{array}{l}\text { Obs. } \\
R^{2} \\
\text { F-Test }\end{array}$ & $\begin{array}{c}3674 \\
0.180 \\
21.89^{* * *}\end{array}$ & $\begin{array}{c}3674 \\
0.224 \\
598.96 * * *\end{array}$ & $\begin{array}{c}3674 \\
0.278 \\
37.92^{* * *}\end{array}$ & $\begin{array}{c}3674 \\
0.184 \\
164.74^{* * *}\end{array}$ & $\begin{array}{l}3674 \\
0.231 \\
4.81^{*}\end{array}$ & $\begin{array}{c}3674 \\
0.286 \\
5.72^{* *}\end{array}$ \\
\hline
\end{tabular}

${ }^{* * *} p<0.01,{ }^{* *} p<0.05,{ }^{*} p<0.1$; Between brackets, are included the p-value of coefficients closed to significance. Robust standard errors in parentheses and clustered at the district level. Space represents the spatial dimension of the RI(closest) index, i.e exp $\left(d_{v, \text { closest }}\right)^{-1}$ while scale is computed as the number of refugees in the closest refugee camp. 
Table 12: Household Fixed Effect (excl. migrants): scale or space

\begin{tabular}{|c|c|c|c|c|c|c|c|c|}
\hline & $\begin{array}{c}(1) \\
\text { HHFE }\end{array}$ & $\begin{array}{c}(2) \\
\text { HHFE }\end{array}$ & $\begin{array}{c}(3) \\
\text { HHFE }\end{array}$ & $\begin{array}{c}(4) \\
\text { HHFE }\end{array}$ & $\begin{array}{c}(5) \\
\text { HHFE } \\
(2 \mathrm{SLS})\end{array}$ & $\begin{array}{c}(6) \\
\text { HHFE } \\
(2 \mathrm{SLS})\end{array}$ & $\begin{array}{c}(7) \\
\text { HHFE } \\
(2 \mathrm{SLS})\end{array}$ & $\begin{array}{c}(8) \\
\text { HHFE } \\
(2 \mathrm{SLS})\end{array}$ \\
\hline & split.incl. & split.incl. & split.incl. & split.incl. & split.incl. & split.incl. & split.incl. & split.incl. \\
\hline $\begin{array}{l}\text { Scale } \\
\text { Scale }^{2}\end{array}$ & $\begin{array}{c}-2.15 \mathrm{e}-06 \\
(1.91 \mathrm{e}-06)\end{array}$ & $\begin{array}{c}-1.76 \mathrm{e}-06 \\
(9.74 \mathrm{e}-07) \\
{[0.131]}\end{array}$ & $\begin{array}{c}-6.79 \mathrm{e}-06^{* * *} \\
(1.53 \mathrm{e}-06) \\
4.83 \mathrm{e}-11 * * \\
(1.33 \mathrm{e}-11) \\
\end{array}$ & $\begin{array}{c}-6.09 \mathrm{e}-06^{* *} \\
(2.22 \mathrm{e}-06) \\
4.22 \mathrm{e}-11^{*} \\
(1.97 \mathrm{e}-11) \\
\end{array}$ & $\begin{array}{c}-2.15 \mathrm{e}-06^{*} \\
(1.16 \mathrm{e}-06)\end{array}$ & $\begin{array}{c}-1.79 \mathrm{e}-06 * * * \\
(6.72 \mathrm{e}-07)\end{array}$ & $\begin{array}{c}-6.53 \mathrm{e}-06 * * * \\
(9.58 \mathrm{e}-07) \\
4.53 \mathrm{e}-11 * * * \\
(7.66 \mathrm{e}-12)\end{array}$ & $\begin{array}{c}-5.84 \mathrm{e}-06^{* * *} \\
(1.41 \mathrm{e}-06) \\
4.03 \mathrm{e}-11^{* * *} \\
(1.23 \mathrm{e}-11)\end{array}$ \\
\hline $\begin{array}{l}\text { Space } \\
\text { Space }^{2}\end{array}$ & $\begin{array}{c}163.2 \\
(111.0)\end{array}$ & $\begin{array}{l}137.0^{*} \\
(55.65)\end{array}$ & $\begin{array}{c}350.9^{* * *} \\
(67.34) \\
-121396 * * \\
(45137)\end{array}$ & $\begin{array}{c}277.5 \\
(163.7) \\
{[0.151]} \\
-86548 \\
(93479) \\
\end{array}$ & $\begin{array}{l}171.7^{* *} \\
(76.70)\end{array}$ & $\begin{array}{c}141.2^{* * *} \\
(45.74)\end{array}$ & $\begin{array}{c}350.8^{* * *} \\
(71.57) \\
-117232^{* * *} \\
(29115)\end{array}$ & $\begin{array}{c}272.8^{* *} \\
(138.1) \\
-85928 \\
(71196) \\
\end{array}$ \\
\hline $\begin{array}{l}\text { Crop Sales } \\
* \text { Scale } \\
\text { NonAgri. } \\
\text { L*Scale } \\
\text { Agri. } \\
\text { L*Scale }\end{array}$ & & $\begin{array}{c}2.25 \mathrm{e}-06^{* *} \\
(6.28 \mathrm{e}-07) \\
1.50 \mathrm{e}-07 \\
(1.07 \mathrm{e}-06) \\
-4.23 \mathrm{e}-06 \\
(4.36 \mathrm{e}-06)\end{array}$ & $\begin{array}{c}2.14 \mathrm{e}-06 * * \\
(6.61 \mathrm{e}-07) \\
-1.16 \mathrm{e}-07 \\
(1.26 \mathrm{e}-06) \\
-3.84 \mathrm{e}-06 \\
(4.04 \mathrm{e}-06)\end{array}$ & $\begin{array}{c}2.23 \mathrm{e}-06^{* * *} \\
(4.93 \mathrm{e}-07) \\
-4.59 \mathrm{e}-07 \\
(8.62 \mathrm{e}-07) \\
-4.39 \mathrm{e}-06 \\
(6.03 \mathrm{e}-06)\end{array}$ & & $\begin{array}{c}2.55 \mathrm{e}-06^{* * *} \\
(8.73 \mathrm{e}-07) \\
1.87 \mathrm{e}-07 \\
(6.24 \mathrm{e}-07) \\
-4.10 \mathrm{e}-06 \\
(2.56 \mathrm{e}-06) \\
{[0.109]}\end{array}$ & $\begin{array}{c}2.41 \mathrm{e}-06 * * * \\
(8.71 \mathrm{e}-07) \\
-3.25 \mathrm{e}-08 \\
(7.09 \mathrm{e}-07) \\
-3.71 \mathrm{e}-06 \\
(2.41 \mathrm{e}-06) \\
{[0.123]}\end{array}$ & $\begin{array}{c}2.60 \mathrm{e}-06 * * * \\
(5.50 \mathrm{e}-07) \\
-4.20 \mathrm{e}-07 \\
(6.29 \mathrm{e}-07) \\
-4.24 \mathrm{e}-06 \\
(3.45 \mathrm{e}-06)\end{array}$ \\
\hline $\begin{array}{l}\text { Business } \\
*_{\text {Scale }} \\
\text { LVST } \\
* \text { Scale }\end{array}$ & & $\begin{array}{c}-9.87 \mathrm{e}-07 \\
(1.25 \mathrm{e}-06) \\
-1.53 \mathrm{e}-07 \\
(1.23 \mathrm{e}-06)\end{array}$ & $\begin{array}{c}-6.99 \mathrm{e}-07 \\
(1.00 \mathrm{e}-06) \\
2.40 \mathrm{e}-07 \\
(1.14 \mathrm{e}-06)\end{array}$ & $\begin{array}{c}-4.59 \mathrm{e}-07 \\
(1.41 \mathrm{e}-06) \\
6.96 \mathrm{e}-09 \\
(1.26 \mathrm{e}-06)\end{array}$ & & $\begin{array}{c}-8.23 \mathrm{e}-07 \\
(7.81 \mathrm{e}-07) \\
-1.99 \mathrm{e}-07 \\
(7.21 \mathrm{e}-07)\end{array}$ & $\begin{array}{c}-5.34 \mathrm{e}-07 \\
(6.94 \mathrm{e}-07) \\
1.89 \mathrm{e}-07 \\
(6.56 \mathrm{e}-07)\end{array}$ & $\begin{array}{l}-4.37 \mathrm{e}-07 \\
(8.62 \mathrm{e}-07) \\
-1.06 \mathrm{e}-07 \\
(6.48 \mathrm{e}-07)\end{array}$ \\
\hline $\begin{array}{l}\text { Crop Sales } \\
* \text { Space } \\
\text { NonAgri. } \\
\text { L*Space } \\
\text { Agri. } \\
\text { L*Space } \\
\text { Business } \\
\text { *Space } \\
\text { LVST } \\
\text { *Space }\end{array}$ & & $\begin{array}{c}20.04 \\
(56.92) \\
201.2^{* *} \\
(73.76) \\
116.0 \\
(283.4) \\
-232.8^{* *} \\
(65.62) \\
105.6^{* *} \\
(38.16) \\
\end{array}$ & $\begin{array}{c}37.17 \\
(64.62) \\
223.1 * * \\
(85.25) \\
94.45 \\
(262.0) \\
-236.0 * * * \\
(41.78) \\
80.30 * * \\
(29.84) \\
\end{array}$ & $\begin{array}{c}32.11 \\
(51.87) \\
281.9^{* * *} \\
(56.62) \\
123.6 \\
(380.0) \\
-243.2^{* *} \\
(65.45) \\
98.36^{* *} \\
(30.47) \\
\end{array}$ & & $\begin{array}{c}-0.0923 \\
(74.55) \\
196.1^{* * *} \\
(38.28) \\
109.2 \\
(168.3) \\
-245.3^{* * *} \\
(41.70) \\
117.8^{* * *} \\
(35.22) \\
\end{array}$ & $\begin{array}{c}22.50 \\
(71.86) \\
213.0 * * * \\
(44.84) \\
87.92 \\
(158.0) \\
-249.6 * * * \\
(39.85) \\
90.20 * * * \\
(25.11) \\
\end{array}$ & $\begin{array}{c}5.543 \\
(73.54) \\
269.2^{* * *} \\
(45.21) \\
116.9 \\
(220.8) \\
-251.0^{* * *} \\
(37.36) \\
115.2^{* * *} \\
(33.05) \\
\end{array}$ \\
\hline $\log (\operatorname{land})$ & $\begin{array}{c}-0.005 \\
(0.0072)\end{array}$ & $\begin{array}{c}-0.002 \\
(0.0078)\end{array}$ & $\begin{array}{l}-0.0026 \\
(0.0076)\end{array}$ & $\begin{array}{c}0.0007 \\
(0.0074)\end{array}$ & $\begin{array}{c}-0.0039 \\
(0.005)\end{array}$ & $\begin{array}{l}-0.0014 \\
(0.0055)\end{array}$ & $\begin{array}{c}-0.0016 \\
(0.005)\end{array}$ & $\begin{array}{l}0.0008 \\
(0.004)\end{array}$ \\
\hline Prop.Lit. & $\begin{array}{c}0.180 \\
(0.111)\end{array}$ & $\begin{array}{c}0.164 \\
(0.120)\end{array}$ & $\begin{array}{c}0.169 \\
(0.121)\end{array}$ & $\begin{array}{c}0.148 \\
(0.0956)\end{array}$ & $\begin{array}{l}0.175^{* *} \\
(0.0707)\end{array}$ & $\begin{array}{l}0.159 * * \\
(0.0748)\end{array}$ & $\begin{array}{l}0.164^{* *} \\
(0.0751)\end{array}$ & $\begin{array}{l}0.144^{* *} \\
(0.0593)\end{array}$ \\
\hline Size & $\begin{array}{l}-0.038 \\
(0.021)\end{array}$ & $\begin{array}{c}-0.041^{*} \\
(0.019)\end{array}$ & $\begin{array}{c}-0.041^{*} \\
(0.019)\end{array}$ & $\begin{array}{c}-0.042^{*} \\
(0.018)\end{array}$ & $\begin{array}{c}-0.038^{* * *} \\
(0.012)\end{array}$ & $\begin{array}{c}-0.04^{* * *} \\
(0.011)\end{array}$ & $\begin{array}{c}-0.04^{* * *} \\
(0.011)\end{array}$ & $\begin{array}{c}-0.042^{* * *} \\
(0.01)\end{array}$ \\
\hline Split-off & $\begin{array}{c}0.120 \\
(0.081)\end{array}$ & $\begin{array}{l}0.107 \\
(0.07)\end{array}$ & $\begin{array}{c}0.110 \\
(0.072)\end{array}$ & $\begin{array}{l}0.0973 \\
(0.074)\end{array}$ & $\begin{array}{c}0.133^{* * * *} \\
(0.047)\end{array}$ & $\begin{array}{c}0.109^{* * *} \\
(0.038)\end{array}$ & $\begin{array}{c}0.114^{* * *} \\
(0.039)\end{array}$ & $\begin{array}{c}0.101^{* * *} \\
(0.036)\end{array}$ \\
\hline $\begin{array}{l}\text { Migr.(Kag) } \\
\text { Prop. } \\
\text { Migr.(out) }\end{array}$ & $\begin{array}{c}0.150 \\
(0.0823) \\
0.326 \\
(0.180)\end{array}$ & $\begin{array}{c}0.229^{*} \\
(0.0961) \\
0.356^{*} \\
(0.174)\end{array}$ & $\begin{array}{c}0.221^{*} \\
(0.0946) \\
0.345 \\
(0.173)\end{array}$ & $\begin{array}{c}0.0688 \\
(0.0828) \\
0.347^{*} \\
(0.162)\end{array}$ & $\begin{array}{c}0.279 \\
(0.268) \\
0.197 \\
(0.378)\end{array}$ & $\begin{array}{c}0.330 \\
(0.277) \\
0.386 \\
(0.354)\end{array}$ & $\begin{array}{c}0.319 \\
(0.273) \\
0.327 \\
(0.332)\end{array}$ & $\begin{array}{c}0.244 \\
(0.345) \\
0.404 \\
(0.352)\end{array}$ \\
\hline $\begin{array}{l}\alpha_{t} \\
\text { Cluster D }\end{array}$ & $\begin{array}{c}0.0962^{* *} \\
(0.0324)\end{array}$ & $\begin{array}{c}0.0585 \\
(0.0409)\end{array}$ & $\begin{array}{c}0.0696 \\
(0.0366)\end{array}$ & $\begin{array}{c}0.0659 \\
(0.0592) \\
\text { sign. }\end{array}$ & $\begin{array}{c}0.0546 \\
(0.0662)\end{array}$ & $\begin{array}{c}0.0409 \\
(0.0742)\end{array}$ & $\begin{array}{c}0.0461 \\
(0.0779)\end{array}$ & $\begin{array}{c}0.0600 \\
(0.0505) \\
\text { sign. } \\
\end{array}$ \\
\hline $\begin{array}{l}\text { Obs. } \\
R^{2} \\
\text { F-Test }\end{array}$ & $\begin{array}{c}3803 \\
0.190 \\
5.20^{* * *}\end{array}$ & $\begin{array}{c}3803 \\
0.234 \\
150.54^{* * *}\end{array}$ & $\begin{array}{c}3803 \\
0.236 \\
133.73^{* * *}\end{array}$ & $\begin{array}{c}3803 \\
0.294 \\
176.57^{* * *}\end{array}$ & $\begin{array}{c}3674 \\
0.185 \\
53.41^{* * *}\end{array}$ & $\begin{array}{c}3674 \\
0.231 \\
53.41^{* * *}\end{array}$ & $\begin{array}{c}3674 \\
0.234 \\
15.99 * * *\end{array}$ & $\begin{array}{c}3674 \\
0.290 \\
31.45^{* * *}\end{array}$ \\
\hline
\end{tabular}

${ }^{* * *} p<0.01,{ }^{* *} p<0.05,{ }^{*} p<0.1$; Between braqgets, are included the $p$-value of coefficients closed to significance. Robust standard errors in parentheses and clustered at the district level. The activity variables are not presented but give similar results than previous tables. 


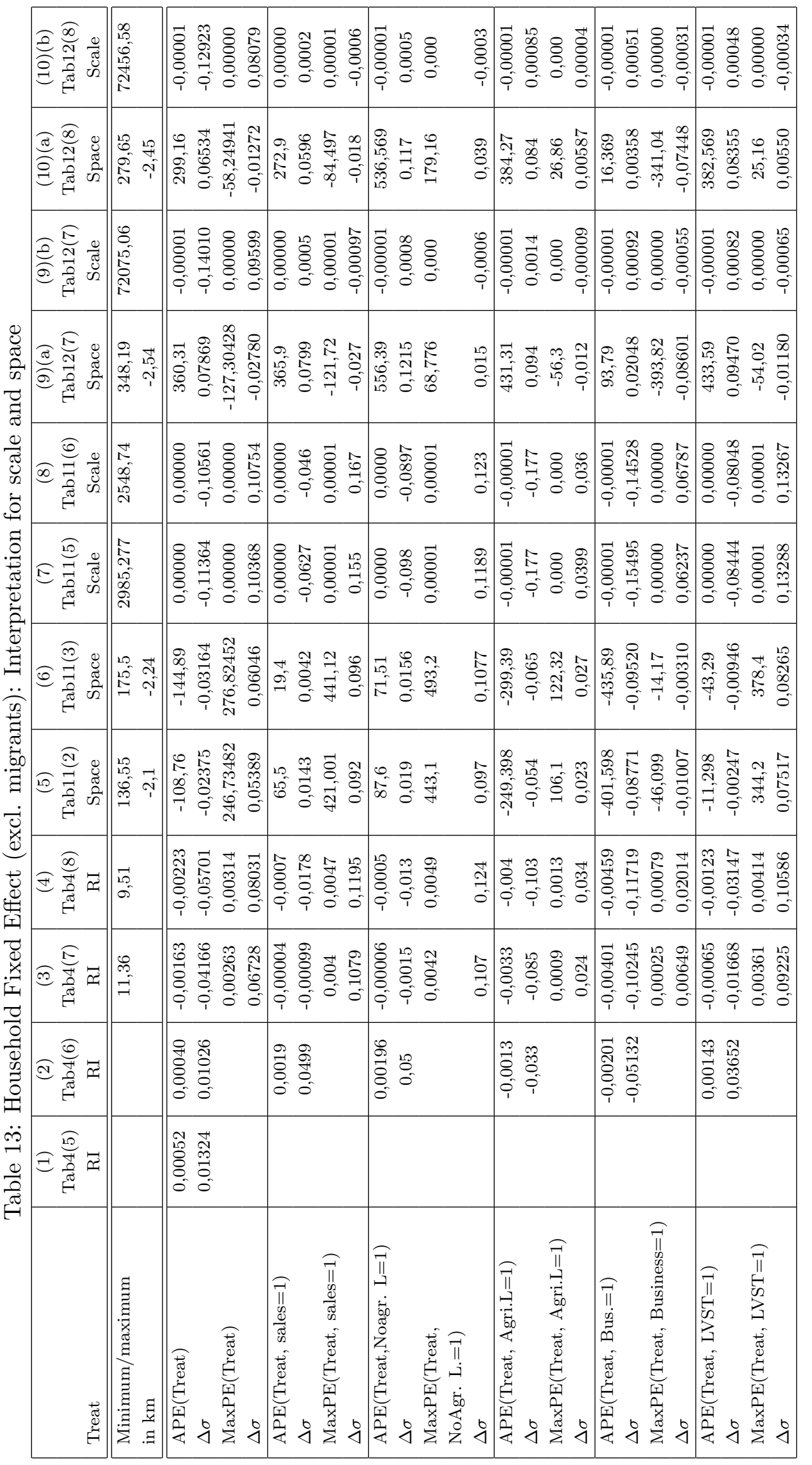

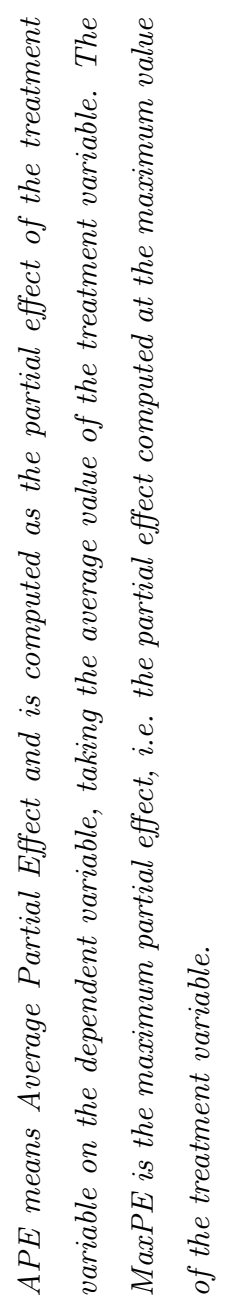




\section{Recent titles \\ CORE Discussion Papers}

2008/80. Jean GABSZEWICZ, Salome GVETADZE, Didier LAUSSEL and Patrice PIERETTI. Pubic goods' attractiveness and migrations.

2008/81. Karen CRABBE and Hylke VANDENBUSSCHE. Are your firm's taxes set in Warsaw? Spatial tax competition in Europe.

2008/82. Jean-Sébastien TANCREZ, Benoît ROLAND, Jean-Philippe CORDIER and Fouad RIANE. How stochasticity and emergencies disrupt the surgical schedule.

2008/83. Peter RICHTÁRIK. Approximate level method.

2008/84. Çağatay KAYI and Eve RAMAEKERS. Characterizations of Pareto-efficient, fair, and strategy-proof allocation rules in queueing problems.

2009/1. Carlo ROSA. Forecasting the direction of policy rate changes: The importance of ECB words.

2009/2. Sébastien LAURENT, Jeroen V.K. ROMBOUTS and Francesco VIOLANTE. Consistent ranking of multivariate volatility models.

2009/3. Dunia LÓPEZ-PINTADO and Juan D. MORENO-TERNERO. The principal's dilemma.

2009/4. Jacek B. KRAWCZYK and Oana-Silvia SEREA. A viability theory approach to a two-stage optimal control problem of technology adoption.

2009/5. Jean-François MERTENS and Anna RUBINCHIK. Regularity and stability of equilibria in an overlapping generations model with exogenous growth.

2009/6. Nicolas GILLIS and François GLINEUR. Using underapproximations for sparse nonnegative matrix factorization.

2009/7. Michel M. DENUIT, Louis EECKHOUDT and Mario MENEGATTI. Correlated risks, bivariate utility and optimal choices.

2009/8. Michel M. DENUIT, Louis EECKHOUDT and Mario MENEGATTI. Adding independent risks in an insurance portfolio: which shape for the insurers' preferences?

2009/9. Antoine BOMMIER and Stéphane ZUBER. The Pareto principle of optimal inequality.

2009/10. Raouf BOUCEKKINE, Jacek B. KRAWCZYK and Thomas VALLEE. Environmental negotiations as dynamic games: Why so selfish?

2009/11. Théophile T. AZOMAHOU, Raouf BOUCEKKINE and Phu NGUYEN-VAN. Promoting clean technologies under imperfect competition.

2009/12. Patrice PIERETTI and Skerdilajda ZANAJ. On tax competition, public goods provision and jurisdictions' size.

2009/13. Jeroen V.K. ROMBOUTS and Lars STENTOFT. Bayesian option pricing using mixed normal heteroskedasticity models.

2009/14. Gauthier de MAERE d'AERTRYCKE and Yves SMEERS. The valuation of power futures based on optimal dispatch.

2009/15. Thierry BRECHET, Tsvetomir TSACHEV and Vladimir M. VELIOV. Prices versus quantities in a vintage capital model.

2009/16. François VANDERBECK and Laurence A. WOLSEY. Reformulation and decomposition of integer programs.

2009/17. Marc FLEURBAEY, Erik SCHOKKAERT and Koen DECANCQ. What good is happiness?

2009/18. David DE LA CROIX and Michel LUBRANO. The tradeoff between growth and redistribution: ELIE in an overlapping generations model.

2009/19. Thierry BRECHET and Fabien PRIEUR. Can education be good for both growth and the environment?

2009/20. Giacomo SBRANA and Andrea SILVESTRINI. What do we know about comparing aggregate and disaggregate forecasts?

2009/21. Marc GERMAIN, Henry TULKENS and Alphonse MAGNUS. Dynamic core-theoretic cooperation in a two-dimensional international environmental model.

2009/22. Claude D'ASPREMONT and Rodolphe DOS SANTOS FERREIRA. Household behavior and individual autonomy.

2009/23. Helmuth CREMER, Philippe DE DONDER and Pierre PESTIEAU. Education and social mobility. 


\section{Recent titles}

\section{CORE Discussion Papers - continued}

2009/24. Maria Eugenia SANIN and Francesco VIOLANTE. Understanding volatility dynamics in the EU-ETS market: lessons from the future.

2009/25. Marco DI SUMMA and Laurence A. WOLSEY. Lot-sizing with stock upper bounds and fixed charges.

2009/26. Johanna M.M. GOERTZ and François MANIQUET. On the informational efficiency of simple scoring rules.

2009/27. Jean GABSZEWICZ, Ornella TAROLA and Skerdilajda ZANAJ. On uncertainty when it affects successive markets.

2009/28. Jerzy A. FILAR, Jacek B. KRAWCZYK and Manju AGRAWAL. On production and abatement time scales in sustainable development. Can we loosen the sustainability screw?

2009/29. María Eugenia SANIN and Skerdilajda ZANAJ. Clean technology adoption and its influence on tradeable emission permit prices.

2009/30. Antoine BOMMIER, Marie-Louise LEROUX and Jean-Marie LOZACHMEUR. On the public economics of annuities with differential mortality.

2009/31. Gilles GRANDJEAN, Ana MAULEON and Vincent VANNETELBOSCH. Connections among farsighted agents.

2009/32. Axel GAUTIER and Xavier WAUTHY. On the nature of price competition under universal service obligations: a note.

2009/33. Santanu S. DEY and Laurence A. WOLSEY. Constrained infinite group relaxations of MIPs.

2009/34. Jean-François MAYSTADT and Philip VERWIMP. Winners and losers among a refugeehosting population.

\section{Books}

H. TULKENS (ed.) (2006), Public goods, environmental externalities and fiscal competition. New York, Springer-Verlag.

V. GINSBURGH and D. THROSBY (eds.) (2006), Handbook of the economics of art and culture. Amsterdam, Elsevier.

J. GABSZEWICZ (ed.) (2006), La différenciation des produits. Paris, La découverte.

L. BAUWENS, W. POHLMEIER and D. VEREDAS (eds.) (2008), High frequency financial econometrics: recent developments. Heidelberg, Physica-Verlag.

P. VAN HENTENRYCKE and L. WOLSEY (eds.) (2007), Integration of AI and OR techniques in constraint programming for combinatorial optimization problems. Berlin, Springer.

P-P. COMBES, Th. MAYER and J-F. THISSE (eds.) (2008), Economic geography: the integration of regions and nations. Princeton, Princeton University Press.

J. HINDRIKS (ed.) (2008), Au-delà de Copernic: de la confusion au consensus ? Brussels, Academic and Scientific Publishers.

\section{CORE Lecture Series}

C. GOURIÉROUX and A. MONFORT (1995), Simulation Based Econometric Methods.

A. RUBINSTEIN (1996), Lectures on Modeling Bounded Rationality.

J. RENEGAR (1999), A Mathematical View of Interior-Point Methods in Convex Optimization.

B.D. BERNHEIM and M.D. WHINSTON (1999), Anticompetitive Exclusion and Foreclosure Through Vertical Agreements.

D. BIENSTOCK (2001), Potential function methods for approximately solving linear programming problems: theory and practice.

R. AMIR (2002), Supermodularity and complementarity in economics.

R. WEISMANTEL (2006), Lectures on mixed nonlinear programming. 